\title{
Acute knee injuries : diagnostic \& treatment management proposals
}

Citation for published version (APA):

Casteleyn, P-PHEG. (1999). Acute knee injuries : diagnostic \& treatment management proposals.

[Doctoral Thesis, Maastricht University]. Universiteit Maastricht. https://doi.org/10.26481/dis.19991028pc

Document status and date:

Published: 01/01/1999

DOI:

10.26481/dis.19991028pc

Document Version:

Publisher's PDF, also known as Version of record

\section{Please check the document version of this publication:}

- A submitted manuscript is the version of the article upon submission and before peer-review. There can be important differences between the submitted version and the official published version of record.

People interested in the research are advised to contact the author for the final version of the publication, or visit the DOI to the publisher's website.

- The final author version and the galley proof are versions of the publication after peer review.

- The final published version features the final layout of the paper including the volume, issue and page numbers.

Link to publication

\footnotetext{
General rights rights.

- You may freely distribute the URL identifying the publication in the public portal. please follow below link for the End User Agreement:

www.umlib.nl/taverne-license

Take down policy

If you believe that this document breaches copyright please contact us at:

repository@maastrichtuniversity.nl

providing details and we will investigate your claim.
}

Copyright and moral rights for the publications made accessible in the public portal are retained by the authors and/or other copyright owners and it is a condition of accessing publications that users recognise and abide by the legal requirements associated with these

- Users may download and print one copy of any publication from the public portal for the purpose of private study or research.

- You may not further distribute the material or use it for any profit-making activity or commercial gain

If the publication is distributed under the terms of Article $25 \mathrm{fa}$ of the Dutch Copyright Act, indicated by the "Taverne" license above, 


\title{
ACUTE KNEE INJURIES
}

\section{Diagnostic \& Treatment Management Proposals}

\section{Proefschrift}

ter verkrijging van de graad van Doctor aan de Universiteit Maastricht, op gezag van Rector Magnificus Prof. dr. A.C. NIEUWENHUIJZEN KRUSEMAN, volgens het besluit van het College van Dekanen in het openbaar te verdedigen op Donderdag 28 oktober 1999 te 16.00 uur

\author{
door
}

Pierre-Paul, Hugues, Ernest, Ghislain CASTELEYN Geboren te Antwerpen in 1946 


\section{Promotores}

Prof. dr. R.G.T. Geesink,

Prof. dr. A.J. van der Linden

Beoordelingscommissie

Prof. dr. J.W.J.L. Stapert,(Voorzitter)

dr. S.B. Bulstra,

Prof. dr. J.P. Clarijs,

Vrije Universiteit Brussel

Prof. dr. J.M.A. van Engelshoven,

Prof. dr. R. Verdonk,

Rijksuniversiteit Gent

ISBN $905487225 \mathrm{X}$

D/1999/1885/014 


\section{TABLE OF CONTENTS}

\section{INTRODUCTION:}

1. General considerations

2. Rationale :

A. Epidemiology

B. Treatment controversies

C. Patient populations

$\begin{array}{rrr} & \text { p. } & 5 \\ & \text { p. } & 5 \\ & \text { p. } & 5 \\ \text { References } & \text { p. } & 7 \\ & \text { p. } & 9 \\ & \text { p. } & 11\end{array}$

II. OWN STUDIES

1. Epidemiology of knee injuries

p. 19

A. Traumatic haemarthrosis of the knee

(J. Bone Joint Surg. 70B : 404 - 406, 1988)

p. 21

B. Arthroscopy in the diagnosis of occult dislocation of the patella

(Acta Orthop. Beig. $55: 381-383.1989$ ) $\quad$ p. 24

2. Diagnostic procedures

p. 27

A. CT-Arthrography and MRI of the patella (Acta Orthop. Belg. $55: 331$ - 338, 1989)

p. 28

B. Chondral lesions of the patella evaluated with computed tomography, magnetic resonance imaging and arthroscopy

(Arthroscopy 6:24 - 29, 1990)

C. IRM du cartilage : comparaison IRM arthroscopie. A propos de 320 cas.

(in : le genou traumatique ef dégénératif. Bard $\mathrm{H}$., Drape JL. Goutallier D, Laredo JP Ed.

p. 161 - 176. Sauramps medical, Montpellier 1997) 
3. Management of $\mathrm{ACL}$ lesions

p. 59

A. Non-operative management of anterior cruciate ligament injuries in the general population

(J. Bone Joint Surg. 78B : 446 - 451, 1996)

p. 60

B. Management of anterior cruciate ligament lesions : surgical fashion, personal whim or scientific evidence ! Study of medium and long term results (Acta Orthop. Belg. : in press, sept. '99)

p. 66

\section{iI. GENERAL CONCLUSION AND PROPOSAL OF A KNEE MANAGEMENT ALGORITME}
1. Summary \& Conclusions
p. 79
2. Treatment algoritme
p. 84
References
p. 86

IV. SAMENVATIING

p. 94 


\section{INTRODUCTION}

\section{General considerations}

Humans belong to the only known species that is both plantigrade and functionally bipedal. The human knee is the result of nearly 400 million years of tetrapod evolution (Dye '87). As stated by Feagin (Feagin ' 88 ) the knee is a "joint of necessity".

Therefore the knee is injured more frequently than any other joint in the human body, because it is part of a weight-bearing limb. and secondly, does not have the stability procured by the joint congruity of the hip and the ankle.

The aim of this work is to study some particular aspects of the pathology generated by knee injuries of the diagnosis of the latter, and to evaluate, if available, long term results of treatment of these lesions. This will be done through personal observations and litterature reviews.

\section{Rationale}

\section{A. Epidemiology}

As orthopaedic surgeons we seem to be challenged by an epidemic of knee injuries. This could be related to social behavior. where recreational and sports activities, as well as work and traffic conditions put the knee at risk. 
Numerous epidemiologic studies confirm these clinical impressions.

The incidence of knee (ligament) injuries in an Health Management Organisation of the San Diego (U.S.A.) area (population : 280.000 members) was studied by Miyasaka and Daniel. They reported 0.98 knee injuries/per 1.000 members/year (Miyasaka '91).

A Danish study performed by Niehlsen and Yde in Aarhus (population 250.000 inhabitants) reported $6 \%$ of all injuries to involve the knee (Niehlsen and Yde '91), with 0.30 anterior cruciate ligament (ACL) and 0.70 meniscal injuries / 1.000 inhabitants.

In a study with special emphasis on patellar dislocation, Casteleyn and Handelberg reviewed acute knee injuries during a 15 month interval in one Emergency Department in the Brussels Belgium area. This revealed a similar incidence of $5.8 \%$ knee injuries (Casteleyn ' 89 ).

Maffulli et al. have reported on (sports) injuries in Asia, with an incidence of knee injuries as high as $10.4 \%$ in Japan. and $35 \%$ in Hong Kong (Maffulli '96).

A prospective 8-year study of students' athletic activities in Hawail revealed 36.3 injuries / 1000 participants / year.

$41.2 \%$ of the latter were knee injuries.

When related to sports participation. the risk of knee injuries and especially of $\mathrm{ACL}$ injuries seems indeed even much higher. Caraffa followed prospectively 600 soccer players in 40 semiprofessional and amateur teams during three soccer seasons. An incidence of $1.15 \mathrm{ACL}$ injuries /team / year was recorded. A proprioceptive training could however reduce this incidence to 0.15 / team / year (Caraffa '96). Hewson reported $42 \mathrm{ACL}$ injuries/ 1.000 players at risk/year in college football (Hewson '86), Levy 0.36 ACL injuries / 1000 exposures in women collegiate rugby players (Levy '97). FEAGIN and associates reported an 
average of $1 \mathrm{ACL}$ injury/day at a large ski area, which represented 1.2 $\mathrm{ACL}$ injury/1.000 skier/day (Feagin '87).

A prospective study of ski injuries between 1972 and 1984 showed a $60 \%$ decrease in lower extremity injuries, but a 2.7 -fold increase in knee sprains (Johnson '91). Knee sprains related to ski increased from $3 \%$ in 1972 to $20 \%$ in 1994, with a proportion of severe knee sprains increasing from $17 \%$ to $70 \%$ (Ettlinger ' 95 ). Another study comparing ski injuries occuring during the 1981- 1982 and the 1993-1994 seasons reported an $89 \%$ decrease of tibial fractures, but a $280 \%$ increase of $\mathrm{ACL}$ injuries (Deibert '98). Although diagnostic procedures improved during this period, this factor can not explain such a huge increase.

This let some authors (Zarins ' 88 , Bobic '92. Frank '97) to project figures of more than 100.000 ski-related ACL injuries / year in het U.S.A., or maybe 250.000 world-wide !

Anyhow, it is already estimated that between 60.000 and 75.000 surgical ACL reconstructions are done per year in the U.S.A. (Johnson '94. Frank '97).

\section{B. Treatment controversies}

Perhaps no other joint has received more attention than the knee. It has been a major focus of both basic sciences and clinical research. Numerous books have been written: numerous symposia have been held; innumerable scientific papers and reviews have been written and presented on this single joint.

So much information has been dispersed that knowledge has almost become a barrier to the furtherance of knowledge. 
The first serious attempt to understand the problem of knee injuries was made by Palmer in his extensive monograph. He rationalized treatment and advised operative treatment (Palmer '38).

This trend towards operative treatment was further enhanced by reports of progressive joint degeneration due to chronic ligamentous pathology (Feagin '79, Noyes '83. Chambat'85, Kannus '87, Barrack '90, Daniel '94).

Recent review articles and editorials challenged however these views, and reemphasized the value of conservative treatment (Johnson '93. Gillquist '93, Lindstrand '95, Dandy '98).

Johnson concluded even that "there are relatively few hard facts concerning treatment outcome, so our statements can be considered only as opinions, with the probability that others will come with different conclusions than we provide here" (Johnson '95).

This uncertainty concerning treatment is to a large extend related to the absence of- in depth- knowledge of the "natural history" of knee injuries (Garrick '88). Many factors contribute to our lack of natural history outcome studies.

First of all . some injuries are unreported, or lost, at many points in the chain of events between the occurance and the treatment of the injury. Each time a case is lost, the remaining group of "found" cases becomes less representative.

Secondly the severity range of the injury can bias the recruiting of cases, with more severe injuries presenting for treatment immediately. On the other hand the duration of symptoms and the recurrence of injuries can also push patients towards seeking medical assistance.

But the passage of time after the injury does not always result in continued disability or recurrent injuries. With time, the functional manifestations of injury could disappear. 
Finally, in the absence of symptoms associated with activities of daily living (A.D.L.), the patients higher acifivity level will be the major determinant of perception of disability.

\section{Patient populations}

It becomes therefore clear that knee injuries have to be related to the concerned patient population (Heier '97, Noyes '97).

The epidemiologic data have already shown the role of sports and recreational activities, in the etiology of these injuries. Further high demand knee activities after the injury. will also have a different impact on the injured knee structures (Roos '95). The outcome of treatment has therefore to be weighted in function of patient activity levels.

But activity level is not the only factor on which patient populations have to be described. Age is also primordial, but this factor is also mostly related to physical activity, as the results of ACL treatment in middle-aged patients do not seem fairly different from those in younger ones (Briges '98, Plancher '98, Vianello '98).

In children and adolescents the problem of ligamentous injuries, and in particular of the A.C.L., seems also quite peculiar. Once considered extremely rare, complete traumatic tears of the $\mathrm{ACL}$ in skeletally immature patients with open physes are now being diagnosed with increasing frequency (Micheli '97). Subsequent meniscal injuries develop in a significant number of these patients.

Non-operative treatment, primary surgical suture- with exception of bony avulsion lesions- and extra-articular stabilisation procedures have not been reported to restore dynamic knee stability or prevent further meniscal damage.

Concerning children and adolescents, surgical reconstructions of the $\mathrm{ACL}$ with drill holes and graft fixation through the physis still raise some 
concern, although preliminary reports of limited patient series do not show growth disturbances (Stanitski '95, Shelbourne '96, Lo' 97).

Gender also seems important, with reports of proportionally higher injury rates in women (Powers '79. Ferretti '92).

Female basket-ball players experienced four times as many $\mathrm{ACL}$ injuries as their male conterparts (Arendt '95) and female soccer players had twice the injury rate of their male conterparts (Bjordal 97).

Although alterations in the ACL cellular metabolism caused by estrogen fluctuations have been demonstrated (Liu '97. Finerman '98), complications and results of $\mathrm{ACL}$ reconstructions are fairly similar in both sexes (Barber-Westin '97).

Many theories have been advanced to explain the increased rate of $\mathrm{ACL}$ injuries among women, including shoe-surface interface, joint laxity, muscle strength and function. joint anatomy and cyclical hormone effects (Arendt '97, Blecher '98. Rozz' '98. Thomas '98).

The presence of androgen receptors in the ACL, suggests that male sex hormones may have an effect on the structure and composition of the ligament (Hamlet '97) 
ARENDT EA, DICK R

Knee injury patters among men and women in collegiate basketball and soccer. NCAA Data and review of literature.

Am. J. Sports Med. 23:694 - 701, 1995

\section{ARENDT EA}

Anterior cruciate ligament injuries in women.

Sports Med. Arthroscopy Rev. 5 : 149 - 155, 1997

BARBER - WESTIN SD, NOYES FR, ANDREWS M

A rigorous comparison between the sexes results and complications after anterior cruciate ligament reconstruction.

Am. J. Sports Med. $25: 514$ - 526, 1997

BARRACK RL, BRUCKNER JD, KNEISL J

INMAN WS, ALEXANDER AH

The outcome of nonoperatively treated complete tears of the anterior cruciate ligament in young adults.

Clin. Orthop. 259: 192-199, 1990

BEACHY G, AKAU CK, MARTINSON M, OLDERR TF

High school sports injuries. A longitudinal study at Punahou school : 1988 to 1996.

Am. J. Sports Med. $25: 675-681,1997$

BJORDAL JM, ARNØY, HANNESTAD B, STRAND T

Epidemiology of anterior cruciate ligament injuries in soccer.

Am. J. Sports Med. $25: 341$ - 345, 1997 
BLECHER AW, RICHMOND JC

Transient laxity of an anterior cruciate ligament-reconstructed knee related to pregnancy. A case report.

Arthroscopy $14: 77-79,1998$

BOBIC V

Current concepts in anterior cruciate ligament reconstruction.

Surgery $10: 241-247,1992$

BRIGGS KK. PLANCHER KD, STEADMAN JR

$\mathrm{ACL}$ reconstruction in patients 40 years and older: long-term follow-up study.

Arthroscopy $14:$ Suppl. $1: 17,1998$

CARAFFA A, CERULI G. PROJETTI M., AISA G, RIZZO A

Prevention of anterior cruciate ligament injuries in soccer. A prospective control study of proprioceptive training.

Knee Surg. Sports Traumatol. Arthroscopy 4:19-21, 1996

CASTELEYN PP. HANDELBERG F

Arthroscopy in the diagnosis of occult dislocation of the patella.

Acta Orthop. Belg. 55:381-383, 1989

\section{CHAMBAT P}

Le ligament croisé antérieur.

In: Cahiers d'enseignement S.O.F.C.O.T.

Duparc J ed.

Expansion Scientifique Française, Paris p. 79-101, 1985.

DANDY DJ, HOBBY JL

Anterior cruciate ligament reconstruction.

J. Bone Joint Surg. 80B : 189 - 190. 1998 
DANIEL DM, FITHIAN DL

Indications for ACL surgery.

Arthroscopy $10: 432-441,1994$

DEIBERTMC, ARONSSON DD, JOHNSON RJ, ETTLINGER CF, SHEALY JE

Skiing injuries in children, adolescents and adults.

J. Bone Joint Surg. 80A : 25 - 32, 1998

DYESF

An evolutionary perspective of the knee.

J. Bone Joint Surg. 69A : 976-983. 1987

ETTUNGER CF, JOHNSON RJ, SHEALY JE

A method to help reduce the risk of serious knee sprains incurred in alpine skiing.

Am. J. Sports Med. $32: 531-537,1995$

\section{FEAGIN JA}

The syndrome of the torn anterior cruciate ligament.

Orthop. Clin. North Am. 10:81-96, 1979

FEAGIN JA, LAMBERT KL, CUNNINGHAM RR:

Consideration of the $\mathrm{ACL}$ injury in skiing.

Clin. Orthop. 216:13-18, 1987

FEAGIN JA

The Knee : Joint of necessity,

In: The crucial ligaments.

Feagin JA ed.

Churchill Livingstone, New York . p. 398-400,1988. 
FERREITI A, PAPANDREA P, CONTEDUCA F, MARIANI PP

Knee ligament injuries in volleyball players.

Am. J. Sports Med. 20: 203-207, 1992

FINERMAN GA, HATCH JD, LIU SH, PANOSSIAN V, WARREN D

Estrogen affects the cellular metabolism of the human $\mathrm{ACL}$ : a potential explanation for female athletic injuries.

Arthroscopy 14 Suppl, 1: 35 - 36, 1998

FRANK CB, JACKSON DW

The science of reconstruction of the anterior cruciate ligament.

J. Bone Joint Surg. 79 A : 1556 - 1576, 1997

\section{GARRICK JG}

Epidemiology of the $\mathrm{ACL}$

In: The crucial ligaments.

Feagin JA Ed.

Churchill Livingstone, New York p. 173-176, 1988

\section{GILLQUIST J}

Repair and reconstruction of the ACL : is it good enough ? Arthroscopy $9: 68-71,1993$

HAMLET WP, LIU SH, PANOSSIAN V, FINERMAN GA

Primary immunolocalization of androgen target cells in the human anterior cruciate ligament.

J. Orthop. Res. 15:657 - 663, 1997

HEIER KA, MACK DR, MOSELEY JB,PAINE R, BOCELL JR An analysis of anterior cruciate ligament reconstruction in middle-aged patients.

Am. J. Sports Med. 25: 527 - 532, 1997 
HEWSON GF, MENDINI RA, WANG JR

Prophylactic knee bracing in college football.

Am. J. Sports Med. $14: 262$ - 266, 1986

JOHNSON RJ, POPE MH

Epidemiology and prevention of sking injuries.

Ann. Chir. Gyn. $80: 110-115,1991$

JOHNSON RJ, BEYNNON BD, NICHOLS CS, RENSTRÖM PA

The treatment of the injuries of the $\mathrm{ACL}$

J. Bone Joint Surg. 74A: 140-151, 1992

JOHNSON RJ

Revision ACL surgery

In : Knee surgery.

Fu F. Harner CD. Vince KG ed.

Williams and Wilkins, Balfimore, p. 877-895, 1994

KANNUS P, JÄRVINEN M

Conservatively treated tears of the anterior cruciate ligament : long term results.

J. Bone Joint Surg. 69A : 1007-1012, 1987

LEVY AS, WETZLER MJ, LEWARS M. LAUGHLIN W

Knee injuries in women collegiate rugby players.

Am. J. Sports Med. $25: 360-362,1997$

LINDSTRAND A

The ACL problem.

Acta Orthop Scand 66: 105-106, 1995. 
LO IK, KIRKLEY A, FOWLER PJ, MINIACI A

The outcome of operatively treated anterior cruciate ligament disruptions in the skeletally immature child.

Arthroscopy $13: 627-634,1997$

LIU SH, AL-SHAIKH RA, PANOSSIAN V, FINERMAN GA, LANE JM

Estrogen affects the cellular metabolism of the anterior cruciate ligament. A potential explanation for female athletic injury.

Am. J. Sports Med. 25: 704 - 709, 1997

MAFFULI N, CHAN KM, MIAO M, FU FH, KUROSAKA M

Athletic knee injuries. Similarities and differences between Asian and Western experience.

Clin. Orthop. $323: 98$ - 105, 1996.

MICHELI LJ, COADY C

Anterior cruciate ligament reconstruction in the pediatric age group.

Sports Med. Arthroscopy Rev. 5: 106-111, 1997

MIYASAKA KC, DANIEL DM, STONE ML, HIRSHAM P

The incidence of knee ligament injuries in the general population.

Am. J. Knee Surg. $4: 3-8,1991$.

NIEHLSEN AB, YDE J

Epidemiology of acute knee injuries : a prospective hospital investigation.

J. Trauma 31 : 1644-1648, 1991

NOYES FR, MOOAR PA, MATTHEWS, PS, BUTLER DL.

The symptomatic ACL deficient knee.

J. Bone Joint Surg. 65A : 154-162, 1983 
NOYES FR, BARBER-WESTIN SD

A comparison of results of arthroscopic-assisted anterior cruciate ligament reconstruction between workers compensation and noncompensation patients.

Arthroscopy $13: 474-484,1997$

\section{PALMER I}

Injuries of the ligaments of the knee joints. A clinical study.

Acta Orthop. Scand. 53. Suppl. $81: 1$ - 282, 1938

PLANCHER KD, STEADMAN JR, BRIGGS KK, HUTTON KS

Reconstruction of the anterior cruciate ligament in patients who are at least forty years old.

J. Bone and Joint. Surg. 80 A : 184 - 197, 1998

POWERS JA

Characteristic features of injuries of the knee in women. Clin. Orthop. 143: 120-124, 1979.

ROOS H, ORNELL M, GÄRDSEN P, LOGMARDER LS, LINDSTRAND A Soccer after $\mathrm{ACL}$ injury : an incompatible combination ? A national survey of incidence and risk factors and a 7 years follow up of 310 players.

Acta Orhop. Scand. 66:107-112, 1995

ROZZI SL, LEPHART SM, GEAR WS, FU FH

Knee joint laxity and neuromuscular characteristics of male and female soccer and basketball players.

Proceedings AOSSM Specialty Day, New Orleans, p. 33, 1998 
SHELBOURNE KD, PATEL DV, MC CARROLL JR

Management of $\mathrm{ACL}$ injuries in the skeletally immature adolescents.

Knee Surg. Sports Traumatol. Arthroscopy 4 : 68-74, 1996

STANITSKI CL

$\mathrm{ACL}$ injuries in the skeletally immature patient : diagnosis and treatment.

J. Am. Acad. Orthop. Surg. 3: 146-158, 1995

THOMAS R, CASCIO B, FEAGIN JA

The influence of the menstrual cycle on ACL laxity.

Poceedings AOSSM Speciality Day, New Orleans, p. 32, 1998

VIANELLO R, RENATO V, RIGON A. MARZANO N

Intra-articular $\mathrm{ACL}$ reconstruction in the over 40 -year-old patient. Arthroscopy 14. Suppl. I. p. 47, 1998. 


\section{Own Studies}

\section{Epidemiology of knee injuries}

A. Traumatic haemarthrosis of the knee

B. Arthroscopy in the diagnosis of occult dislocation of the patella 


\title{
TRAUMATIC HAEMARTHROSIS OF THE KNEE
}

\author{
P. P. CASTEleYN, F. HANDElBERG, P. OPDECAM
}

From the Academic Hospital of the Vrije Universiteit Brussel, Belgium

We have investigated a prospective series of 100 acute traumatic haemarthroses of the knee in a general Ion-athletic population. All the patients had normal radiographs and an aspiration which confirmed the aemarthrosis, before undergoing ligament testing and an arthroscopic examination under anaesthesia. Only ne patient had no serious pathology; in the other 99 a total of 193 lesions were recorded. Thirty knees had aly one isolated lesion, 69 had combined lesions. This study confirms the serious nature of an acute traumatic vemarthrosis of the knee, even in non-athletic patients.

ute haemarthrosis of the knee, without gross joint has, in the past, often been considered benign on-Jones 1946); this opinion was based on clinical idiological examination. Recent arthroscopic stuhowever, have reported a very high number of urticular lesions in such cases (Gillquist, Hagberg iretop 1977: DeHaven 1980; Noyes, Basset et al. These findings might, of course, be atypical since atients were almost exclusively young athletes ed in sports accidents and clinical studies of less ic patients seemed to confirm the benign nature of taemarthroses (Jain, Swanson and Murdoch 1983). $s$ to clarify this controversy that we decided to $\mathrm{m}$ a consecutive, prospective arthroscopic study in sral patient population.

\section{PATIENTS AND METHODS}

aaterial of this study consisted of a consecutive of 100 patients with haemarthrosis of the knee who ited at the emergency department of our hospital, ho met the following criteria: early onset of knee $\mathrm{ag}$, following a recent acute injury; confirmation of emarthrosis by aspiration; exclusion of gross joint or patellar dislocation by routine clinical examinand exclusion of fractures or osteochondral tions by radiographs, including skyline views or rams if necessary.

he series had a broad age range ( 12 to 61 years) gh it mostly concerned young individuals, with a

asteleyn, MD, Assistant Professor

delberg. MD, Resident

scam, MD, Professor and Chairman

nent of Orthopaedics and Traumatology, Akademisch Ziekenife Universiteit Brussel, Larbeeklaan, 101, B-1090 Brussels,

rondence should be sent to Dr P. P. Casteleyn.

British Editorial Society of Bone and Joint Surgery

$20 \mathrm{X} / 88 / 3120 \$ 2.00$

Joint Surg $[\mathrm{Br}]$ 1988;70-B:404-6. mean age of 24 years (Fig. I). The sex ratio was predominantly male ( 80 to 20 ).

The causal injuries were diverse, but falls and other accidents at home ( 26 patients), as well as hobbies and recreational activities (54 patients) dominated; only 14 were traffic accidents and six were accidents at work. Most were low energy injuries. There were no high level athletes in the sports trauma group, since these were mostly referred direct to our orthopaedic department and are therefore not included in this study.

All the patients in our series were further evaluated by clinical examination under general or epidural anaesthesia, followed by arthroscopy; the delay between trauma and this examination was kept as short as possible, in order to avoid secondary lesions (Fig. 2). The arthroscopies, which represented about $10 \%$ of all the arthroscopic examinations carried out in our orthopaedic department during the same period, were performed by only two surgeons (PPC and FH). A standard set-up was used, with large-bore high flow irrigation, but no pump. A tourniquet and leg holder were used in most cases. Probing was always done, and the posterior cruciate ligament was visualised with a $70^{\circ}$ arthroscope. The arthroscopic criteria for the diagnosis of a collateral ligament injury were a blood infusion in the medial or lateral gutter, and abnormally easy opening of the medial or lateral compartment.

Statistical evaluation of the data was performed by Student's t-test and the chi-square test.

\section{RESULTS}

No complications could be attributed to the examinations under general or epidural anaesthesia, or to the arthroscopies; and there were no statistically significant differences in the mean age, or sex ratio between the different trauma groups.

Clinical examination under anaesthesia revealed anterior cruciate ligament injuries in 67 cases, posterior cruciate ligament injuries in nine, and collateral ligament 


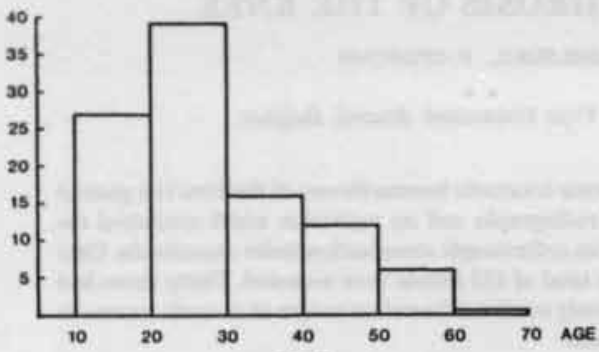

Fig. 1

Age distribution of 100 patients with an acute haemarthrosis of the knee.

Table I. Lesions found at arthroscopy in the different trauma groups

\begin{tabular}{llllll}
\hline & Recreational & Hene & Work & Traffic & Total \\
\hline $\begin{array}{l}\text { Anterior } \\
\text { cruciate }\end{array}$ & 45 & 17 & 4 & 9 & 75 \\
$\begin{array}{l}\text { Posierior } \\
\text { cruciate }\end{array}$ & - & 1 & - & 10 & 11 \\
Collateral & 15 & 6 & - & 4 & 25 \\
Menisci & 31 & 8 & 3 & 9 & 51 \\
Capular & 5 & 3 & 4 & 6 & 18 \\
Chondral & 4 & 6 & - & 3 & 13 \\
Total & 100 & 41 & 11 & 41 & 193 \\
\hline
\end{tabular}

* cases

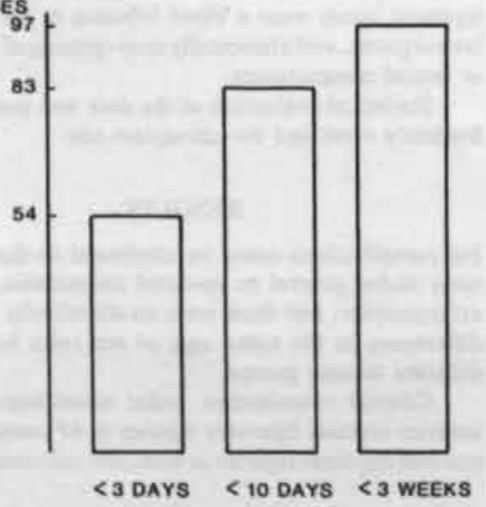

Fig. 2

Delay between trauma and arthroscopy.

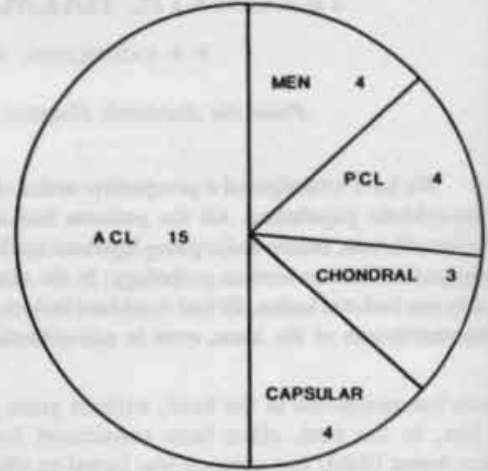

Fig. 3

Isolated lesions found in $\mathbf{3 0}$ cases.

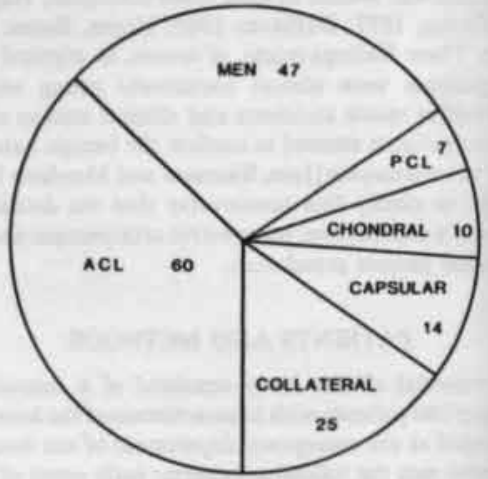

Fig. 4

Combined, multiple lesions found in 69 cases. MEN, meniscal: $\mathbf{A C L}$, anterior cruciate ligament; $\mathrm{PCL}, \mathbf{p o s}$ : terior cruciate ligament.

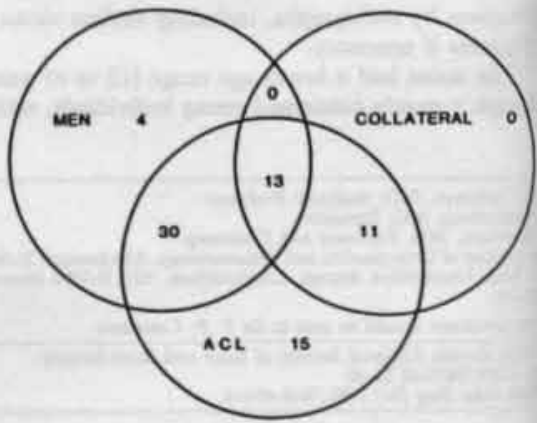

Fig. 5

Venn diagram of the most frequently encountered combined lesions of $\mathrm{ACl}$. menisci and collateral tigaments. 
injuries in 23. The most consistently positive test for anterior cruciate lesions was the Lachman sign (63 cases). The anterior drawer sign at $90^{\circ}$ of flexion (38 cases) and the pivot shift sign (16 cases) showed lower sensitivity.

The arthroscopic technique used permitted complete visualisation of all compartments of the knee. In only one case was no important intra-articular lesion found. In the other 99 a total of 193 lesions were recorded; 30 knees presented only one isolated lesion, 69 presented multiple or combined lesions (Figs 3, 4, and 5).

Only a few statistically significant correlations were found (Table I). Almost all the posterior cruciate lesions (10 out of 11) were caused by traffic accidents, and none were sports-related. Anterior cruciate injuries, isolated or combined, were statistically more frequent in sports injuries $(p<0.005)$, and chondral lesions were predominantly non-sports related $(p<0.005)$.

The diverse nature of the injuries made precise information about the mechanism unreliable. A popping noise was mentioned by only 21 patients: 20 with anterior cruciate ligament injuries (of which there were 75 in all) and one with a meniscal injury (of which there were 51).

\section{DISCUSSION}

Although 54 of the 100 haemarthroses in this study followed recreational activities, it is important to stress that no high level athietes were included. The population studied was a broad mix of patients of different ages, with diverse types of accident, typical of those seen in a general trauma centre; this cannot be compared with the young athletic population seen in specialised sports centres. Nevertheless, our results show almost exactly the same number and distribution of intra-articular lesions as those reported from such centres.

In our study anterior cruciate lesions were somewhat more frequent in sports injuries, while posterior cruciate lesions seemed to require higher energy trauma as in traffic accidents. The low incidence of chondral injuries, compared with previous series, can be explained by our exclusion of all patients with radiologically visible lesions.

We also found that clinical examination, even when performed under anaesthesia, still underestimated the extent and the number of lesions found at arthroscopy. The combination of all our clinical tests successfully diagnosed only $89 \%$ of the anterior and $82 \%$ of the posterior cruciate lesions found arthroscopically. We have the impression that the pivot shift sign can be masked in acute injuries by soft-tissue effusion and joint distension; this could explain its low frequency in our hands.

The importance of a correct diagnosis in patients with a haemarthrosis of the knee has been emphasised in various studies (Noyes, Paulos et al. 1980: Mariani, Puddu and Ferretti 1981). These have demonstrated that undiagnosed and untreated knee injuries have a poor outcome, and Smillie (1978) has stated that: " . ... there are few worse errors than to enclose a recently injured knee in a plaster cast without a diagnosis ....".

Our results do not imply that each lesion found arthroscopically needs to be treated surgically. We believe that in a general patient population there is a definite place for conservative management of knee injuries and that treatment needs to be tailored to the requirements of each individual patient.

No benefits in any form have been received or will be received from a commercial party related directly or indirectly to the subject of this article.

\section{REFERENCES}

DeHaven KE. Diagnosis of acute knee injuries with hemarthrosis. Am J Sports Med 1980;8-14.

Gallquist J, Hagberg G, Oretop N. Arthroscopy in acute injuries of the knee joint. Acta Orthop Scand 1977:48:190-6.

Jain AS, Swanson AJG, Murdoch G. Hemarthrosis of the knee joint. Injary 1983:15:178-81.

Mariani PP, Pudde P, Ferretti A. Hemarthrosis treated by aspiration and casting: how to condemn the knee. Am J Sports Med 1982:10:343-5.

Noyes FR, Basset RW, Grood ES, Butler DL. Arthroscopy in acute traumatic hemarthrosis of the knee: incidence of anterior cruciate tears and other injuries. J Bone Joint Surg /Am] 1980;62-A -687-95.

Noyes FR, Paulos L. Moosr LA, Siger B. Knee sprains and acute knee hemarthrosis: misdiagnosis of anterior cruciate ligament tean. Phys Ther 1980;60(12):1596-1601.

Smillie IS. Infaries of the knee joint. Sth ed. Edinburgh etc: Churchill Livingstone, 1978:69.

Watson-Jones R. Fractures and joint iryuries. 3rd ed. Edinburgh: E \& S Livingstone Ltd, 1946:702. 


\title{
ARTHROSCOPY IN THE DIAGNOSIS OF OCCULT DISLOCATION OF THE PATELLA
}

\author{
by P.P. CASTELEYN and F. HANDELBERG*
}

The authors investigated the incidence of acute patellar dislocation by clinical and radiologic examination and by arthroscopy. Acute patellar dislocation represented $2.44 \%$ of all knee injuries in their series, and only $25 \%$ of the former were evident at the initial examination.

Keywords : arthroscopy ; dislocation ; patella. Mots-clés : arthroscopie : luxation : rotule.

\section{RESUME}

P.P. CASTELEYN et F. HANDELBERG - Intért de l'arthroscopie dans le diagnostic des luxations occultes de la rotule.

Les auteurs ont recherche lincidence de la luxation ȧzuê de la rotule par l'etude clinique, radiologique et arthroscopique.

La luxation aigué de la rotule represente $2,44 \%$ de l'ensemble des lesions traumatiques du genou. Seulement $25 \%$ des luxations sont évidentes lors du premier examen.

\section{SAMENVATTING}

P.P. CASTELEYN en F. HANDELBERG Arthroscopie bij de diagnose van occul patellaluxatie.

De auteurs onderzochten de incidentie van acul patellaluxatie door middel van klinisch onderzoel radiologie en anthroscopie.

De acute patellaluxatie zou $2,44 \%$ van all knietraumata vertegenwoordigen. Slechts $25 \% \mathrm{va}$ deze luxaties kan bij het eerste onderzocl waargenomen worden.

\section{INTRODUCTION}

The diagnosis of patellar subluxation is probably 2 much overused as the diagnosis of chondromalaci patellae.

The statistics of the Hughston Orthopaedic clini reveal that of 1200 patients in which the forme

- Department of Orthopaedics and Traumatology, Ac demic Hospital of the Vrije Universiteit Brusse Brussel (Belgium)

Travail prtsente au Congrits of "Orthopaedica Belgica" ter d Liege les 21 at 22 mai 1988.

Acta Orthopadica Belgica, Vol. $55-3-19$ 
diagnosis was evoked only 708 cases could be substantiated as symptomatic patellar subluxation or dislocation, either acute or chronic (3).

Furthermore, the relationship between subluxation and dislocation is at best not clear. Patellar subluxation is usually associated with certain morphological or biomechanical predisposing factors.

On the other hand, does patellar dislocation occur in normal or in pathological knees? Does acute patellar dislocation predispose to recurrent patellar subluxation and dislocation? (2).

These questions cannot be solved because the real incidence of acute patellar disiocation is obscure, owing to the different pattems of presentation of this traumatic entity. Some patients are seen with the patella still dislocated laterally. Others show an acutely swollen and painful knec, with a clear history of patellar luxation and immediate reduction. A vast number of patients complain later on and can only remember an acute knee injury, for which no clear diagnosis was established (1).

\section{MATERIALS AND METHODS}

We postulated that an occult dislocation of the patella could only occur with a rupture of the medial retinaculum patellae and/or of the vastus medialis obliquus muscle. This would lead to some form of hemarthrosis.

Since it is a policy of our department to perform arthroscopy on all knees presenting with an acute hemarthrosis, all occult patellar dislocations would therefore be found in this group.

The charts of all arthroscopies performed during a 1S-month time interval (January 1986 to Marchi 1987) were reviewed.

The cases with a fresh rupture or hematoma of the medial patellar rectinaculum were examined in detail, and their clinical records, radiographs, and video-tapes were studied.

\section{RESULTS}

During the time interval studied (15 months), 984 acute knec injuries were seen in our Department of Orthopedics and Traumatology.

Only 5 presented a persistently dislocated patella ot had an undisputable history of acute patella: dislocation.

The 269 arthroscopic procedures revealed a total o? 19 occult dislocations. The diagnosis of patellar disiocation had not been evoked before arthroscop: on the basis of history, clinical or radiologica! examination in the latter cases.

Most of the cases of occult dislocation had a simila: clinical pattern, consisting of indirect knee trauma. mild acute hemarthrosis and painful functional impairment (especially in fexion and valgus stress). without any ligamentous laxity.

It is noteworthy that associated traumatic chondral lesions of the lateral condyle and of the medial patellar facet were also seen in cases with only a hematoma of the medial retinaculum.

The retrospective review of the radiographs detected only some minor osteochondral lesions of the patella and/or the femoral condyles on skyline views. AP and lateral views were always normal (4).

The follow-up of all 24 dislocations, during a 1- to 2-year period, did not show any evidence of further subluxation or dislocation of the patella.

\section{DISCUSSION - CONCLUSION}

This study shows that 2.44 acute dislocations of the patella can be expected for each 100 knee injuries. Only about $\mathbf{2 5 \%}$ of these dislocations are apparent on the first examination, or show clear clinical or radiological signs of a reduced acute dislocation.

Relying on our epidemiologic data, one can expect to see 7 occult dislocations for each 100 arthrosco pies performed for acute knee injuries. 
Our limited series and follow-up does not allow any conclusions to be drawn concerning the relationship between acute dislocation and recurrent subluxation and dislocation. This study confirms the necessity to perform arthroscopy on every patient with acute knee trauma presenting with hemarthrosis, and in whom no clear diagnosis can be made by clinical and/or radiological examination.

Only the combination of clinical and radiologic examination and arthroscopy can provide a precise evaluation of the incidence of acute patellar luxation.

\section{REFERENCES}

1. BORING T.H. O'DONOGHUE D.H. Acute patelly dislocation. Clin. Orthop., 1978, 136, 182-185.

2. FICAT R.P., HUNGERFORD D.S. Disorders of it patello-femoral joint. Ed. Masson, Paris, 1977.

3. HUGHSTON J.C., WALSH W.M., PUDDU G.C Patellar subluxation and dislocation. Ed, WB Saunders, Philadelphin, 1984.

4. TEN THIJE J.H. FRIMA A.J. Patellat dislocation and osteochondral fractures. Neth. J. Surg., 1986 38. 150-153. 
2. Diagnostic procedures

A. CT arthrography and MRI of the patella

B. Chondral lesions of the patella evaluated with computed tomography, magnefic resonance imaging and arthroscopy

C. IRM du cartilage. Comparaison IRM -arthroscopieà propos de 320 cas 


\title{
CT ARTHROGRAPHY AND MRI OF THE PATELLA
}

\author{
by F. HANDELBERG ${ }^{\bullet}$, M. SHAHABPOUR ${ }^{\bullet}$, F. VAN BETTEN", \\ C. PIERRE JEROME*, P.P. CASTELEYN* and P. OPDECAM*
}

The importance of CT scanning in the diagnosis of patello-femoral disorders is reviewed and illustrated. CT double-contrast technique is compared to Magnetic Resonance Imaging (MRI) using both clinical examples and a cadaver study. The authors demonstrate the superiority of MRI to CT in detecting retropatellar cartilage lesions.

Keywords : knee : CT double-contrast technique ; magnetic resonance imaging ; retropatellar cartilage : chondromalacia.

Mots-clés : genou ; arthro-scanner ; imagerie par résonance magnétique ; cartilage rotulien ; chondromalacic.

\section{RESUME}

F. HANDELBERG, M. SHAHABPOUR, F. VAN BETTEN, C. PIERRE JEROME, P.P. CASTELEYN et P. OPDECAM - Arthro-scanner et NMR de la rotule.

L'importance de la tomographie computériste dans le diagnostic des dérangements fémoro-patellaires est résumée et illustrée. La technique de l'arthro-scanner est comparée à la Résonance Magnétique (IRM) à l'aide d'exemples cliniques et d'une étude sur cadavres.

Les auteurs démontrent la nette supériorité de sur l'arthro-scanner dans l'évaluation du car rotulien.

\section{SAMENVATTING}

F. HANDELBERG, M. SHAHABPOUR, VAN BETTEN, C. PIERRE JEROME, CASTELEYN en P. OPDECAM Arthrographie en $M R I$ van de patella.

Het belang van de CT scan in de diagnose femoropatellair lijden wordt samengeva geillustreend.

De CT dubbelcontrast techniek wordt vergel met de Magnetische Resonantie (MR) door m van zowel klinische voorbeelden, als aan de van een kadaverstudic.

De auteurs tonen het duidelijk overwicht van $M$ CT ter evaluatic van het retropatellair kraakt aan.

\footnotetext{
Akademisch Ziekenhuis Vrije Universiteit Brussel (B - Orhopedies and Trauma Department.

-. Radiology Department.

Travail prisente au Congres of "Orthopaedica Belgica a Litge les 21 et 22 mai 1988.
}

Acta Orthopadica Belgica, Vol. $55 \cdot 3$ 


\section{INTRODUCTION}

the early nineteen-eighties, the first publications ppeared conceming CT scanning of the knee joint. It that time radiologists and orthopedic surgeons of ur hospital were already deeply involved in the tudy of patellar disorders $(1,2)$.

Ur colleagues concluded that measurements of the ulcus angle according to Ficat were inaccurate on $\mathrm{r}$, as different angles were found on different lices. They also found that using Wiberg's lassification of the patellar shape on CT. $50 \%$ of a patellae did not correspond to the type described n the axial roentgenogram. Wiberg's classification as thus not reliable on CT.

more useful contribution of CT to the study of the nee was visualization of the retropatellar cartilage sing double-contrast technique. Various authors 3. 4, 5. 6, 7, 12, 14) have studied the congruity indicating that the cartilage exactly follows the ontour of the patella), the regularity of the contour f the cartilage, the uptake of contrast material in the ase of fissures and ulcerations, and the teasurement of the thickness of the cartilage. All is is done without the superpositions obtained rith axial anthrograms.

igure 1 shows the right knee of a 25-year-old :male investigated with double-contrast technique. demonstrates slight erosive lesions of the lateral icet of the patellar cartilage. Figure 2 shows her left nee. where a lateral subluxation appears clearly. esides moderate sclerosis of the subchondral bone, o evident pathology of the cartilage is seen. As this atient complained of bilateral anterior knee pain, a lease of the lateral retinaculum was performed on th sides with excellent results.

or the last few years, magnetic resonance imaging 4RI) has provided a revolutionary technique for e investigation of human joints. The advantages of is method include absence of ionizing radiation

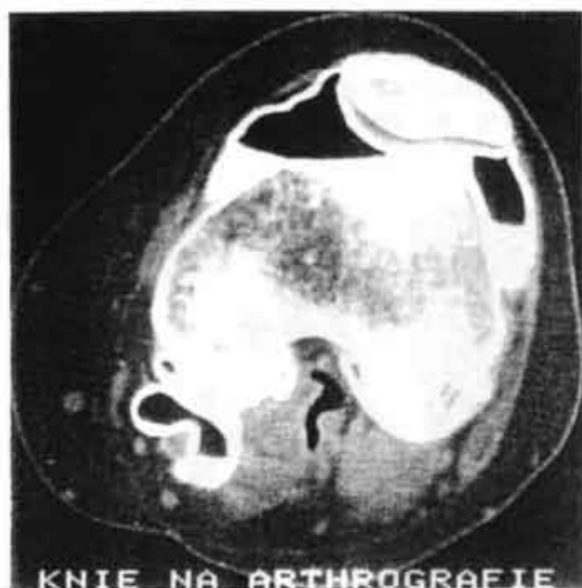

FIG. 1.- Right knee : slight erosive lesions of the lateral facet of the patella

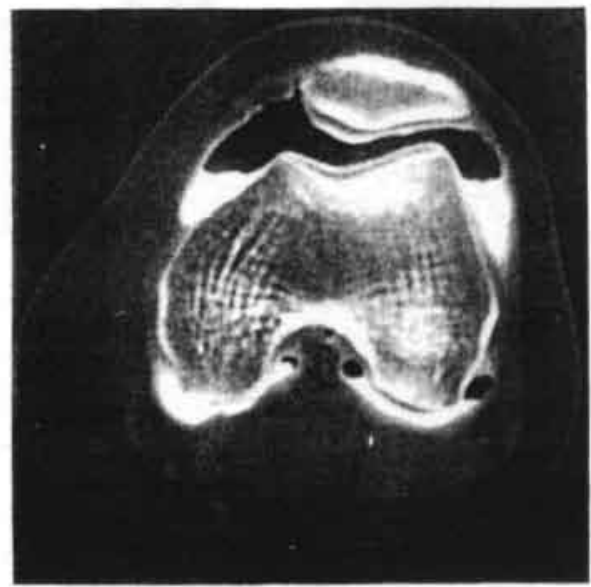

FIG. 2.- Left knec : lateral subluxation of the patella, Moderate subchondral selerosis

and multiplanar imaging capability without any manipulation of the knee. The excellent soft tissue contrast allows the delineation of the different structures (fig. 3) : the medullary bone appears white, owing to its high content of fat (high signal intensity) : the cortical bone has a low signal 
intensity and appears dark : the articular cartilage has an intermediate signal intensity and is very well delineated ; and the cruciate ligaments, quadriceps and patellar tendons are clearly seen, as well as fat and muscles surrounding the bony structures.
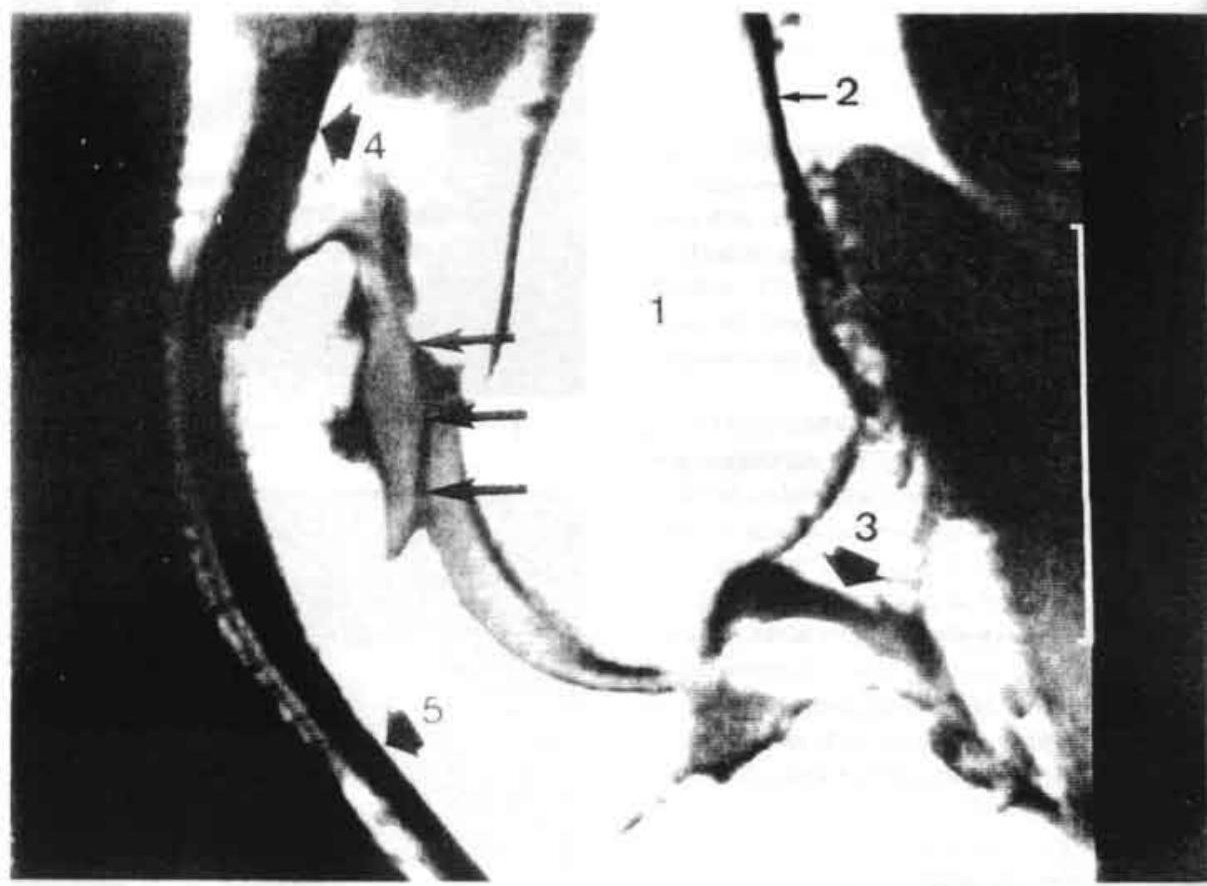

FIG. 3. - TI-weighted MR image in the sagittal plane. - Medullary bone (1), cortical bone (2), retro-patellar canilage (arrows), . PCL (3), quadriceps tendon (4), patellar tendon (5).

There are no studies on the use of MRI in the diagnosis of recurrent dislocation, but its value in the evaluation of the retropatellar cartilage is indisputable $(15,16,17)$.

In figure 4 , an early stage of chondromalacia is detected as a round area of low signal intensity within the cartilage (sagittal T2-weighted image). Without the use of contrast material, MRI is also capable of demonstrating ulcerations in the cartilage. The surrounding synovial fluid appears bright on the T2-weighted image, clearly delineates the cartilage and penetrates within the ulceration (fig. 5).

On the double-contrast CT scan of the right knee of a 36-year-old man complaining of anterior knee pain, no clear cartilaginous lesion was seen (fig. 6). 


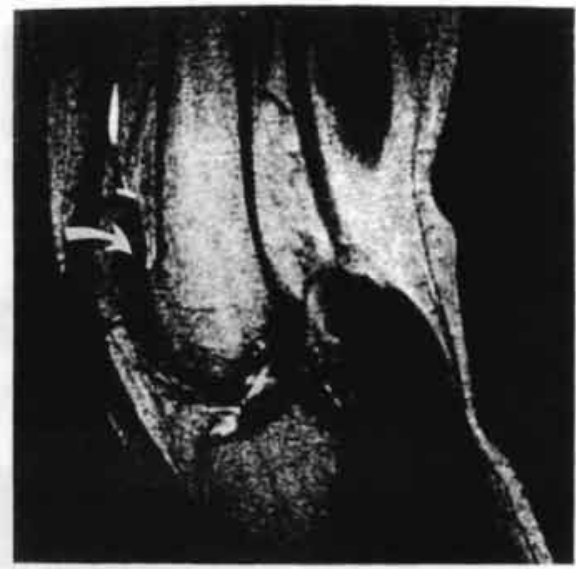

FIG. 4.- Sagitual MR image (T2-weighted). $\leftarrow \quad$ Early stage of chondromalacia (arrow).

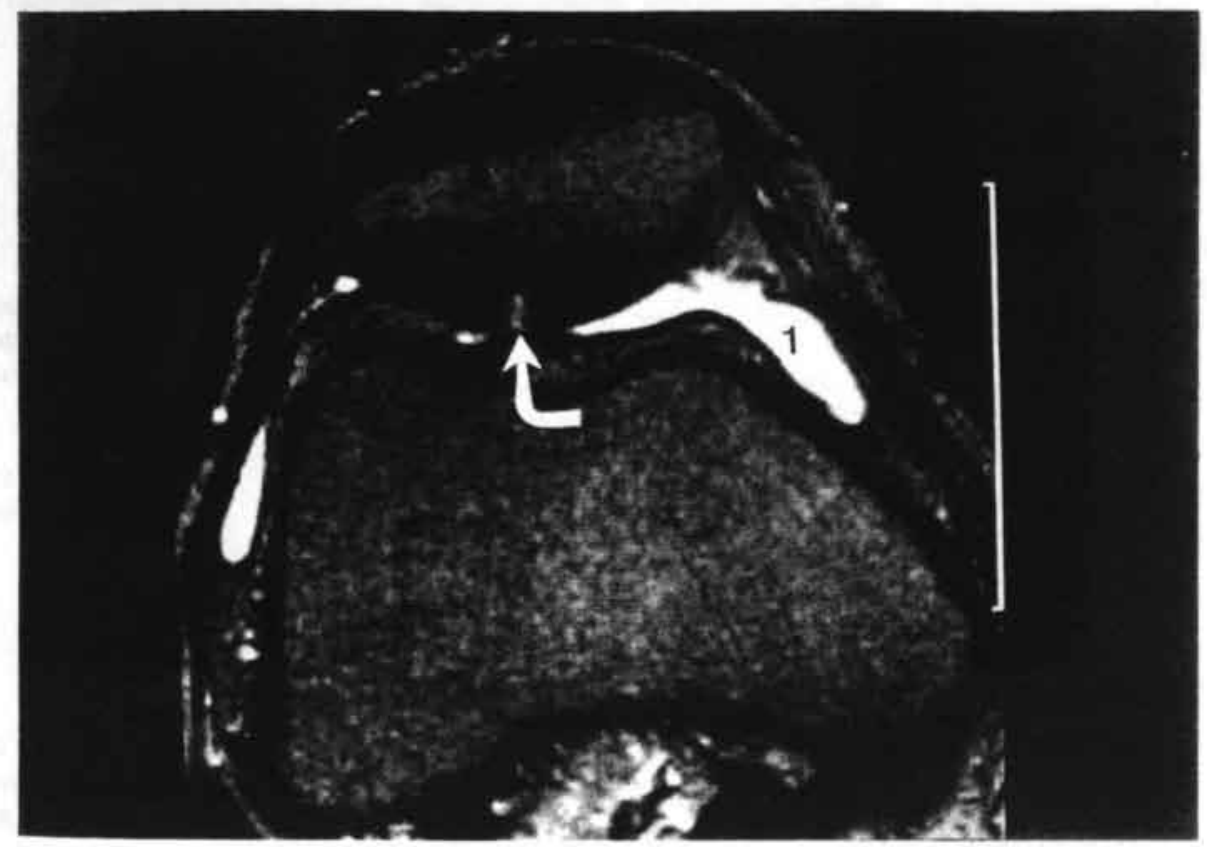

FIG. 5.- MR image in the axial plane (T2-weighted), - Ulceration in the retropatellar cartilage 


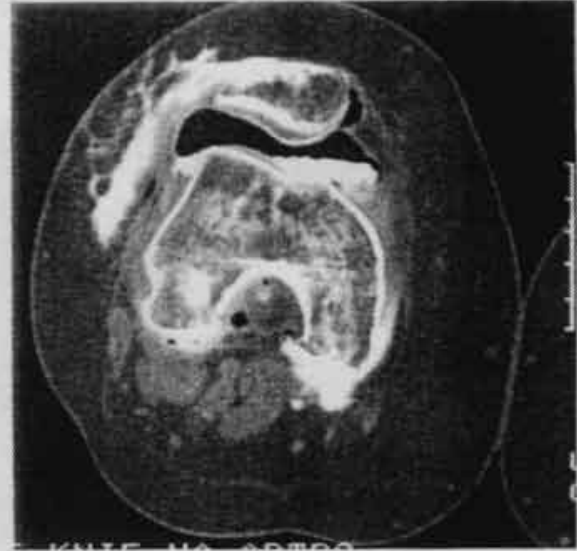

NIG. 6.- Double-contrast CT-scan of the right knee. No clear cartilaginous lesions

An MRI axial view of the same knee, 3-mm thick, shows a fissure of high signal intensity on the lateral facet. A more severe ulceration is also seen on the opposite side (fig. 7). The diagnosis of chondromalacia was confirmed arthroscopically in this case.

A few authors have already published their findings concerning cartilage defects $(9,10,15,16)$. They studied and compared artificially induced lesions on cadaver knees, as well as arthroscopically confirmed lesions in patients. It appeared that MRI was capable of detecting most of the lesions equal to or larger than $4 \mathrm{~mm}$ in width and $3 \mathrm{~mm}$ in depth. To detect defects as small as $2 \mathrm{~mm}$, Gylys-Morin used intraarticular Gadolinium DTPA as contrast material in a cadaveric study (10). Until now, there is no published study comparing MRI and $\mathrm{CT}$ doublecontrast technique. Our purpose is to compare the findings of the two methods.

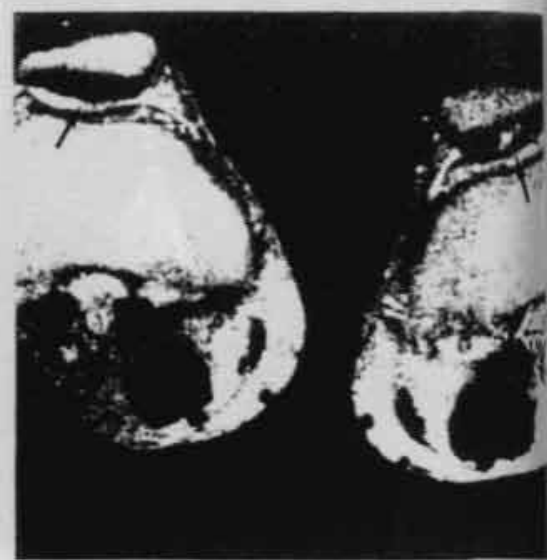

FIC. 7. MR image in the axial plane, both knees. Rip fissure of the lateral facet. Left : ulceration.

\section{MATERIALS AND METHODS}

On fresh cadaver knees, drill holes of different si and depth were surgically placed. The width of drill holes ranged from $0.8 \mathrm{~mm}$ to $5 \mathrm{~mm}$ witht different depths, 1 and $2 \mathrm{~mm}$.

After closure of the knee, first MRI then examinations with contrast injection wi performed.

\section{RESULTS}

Lesions of 1.5 and $2 \mathrm{~mm}$ could be detected on by using a high-resolution program and $2-\mathrm{mm}$ th slices only after a second attempt (fig. 8) :0.8 E holes were not recognized. 
F. HANDEL BERG, M. SHAHABPOUR, F, VAN BETTEN, C. PIERRE JEROME. P.P. CASTELEYN, P. OPDECAM
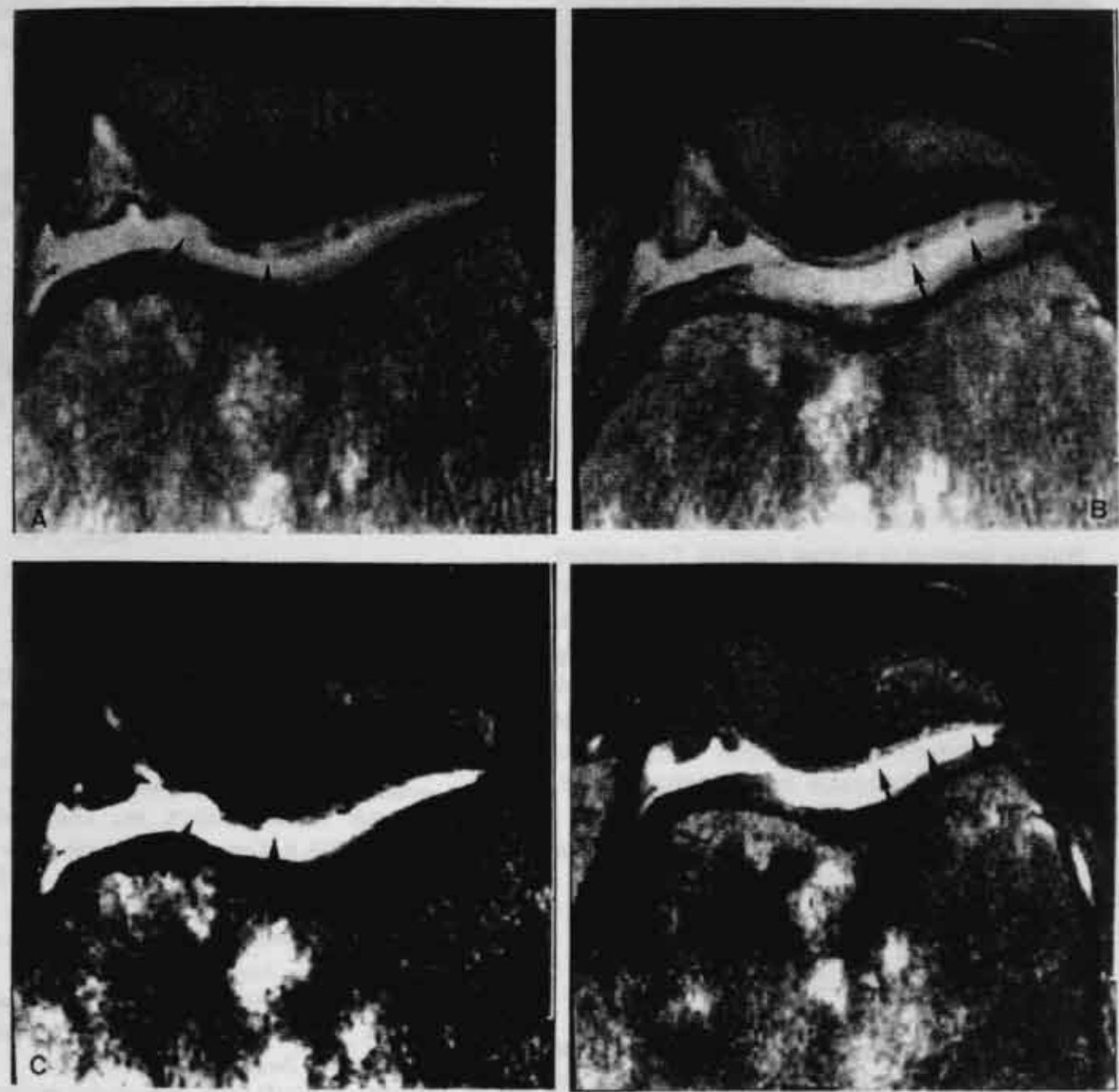

FIG. 9. MRI : Axial view showing the two large defocts on the medial facet ( 5 and $3 \mathrm{~mm}$ ) (a, c). The upper contiguous slice shows the three smaller defects (from medial to lateral respectively $2,1.5$ and $0.8 \mathrm{~mm})(\mathrm{b}, \mathrm{d})$. 


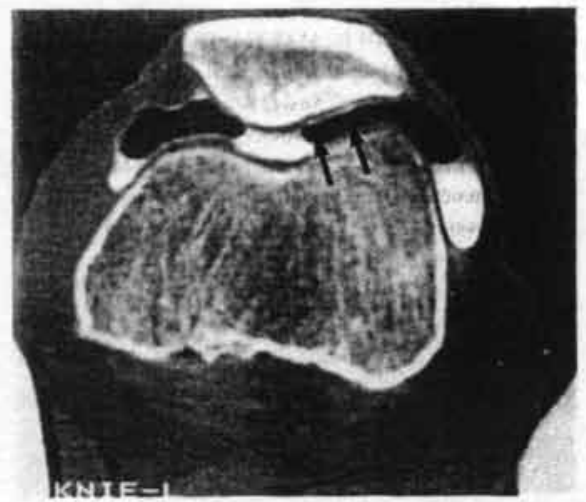

FIG. 8.- CT double-contrast study of a cadaver knee. 1.5. and 2-mm drill holes.

Without injection of contrast material, $\mathrm{Tl}$-weighted MR-images showed three small dark lesions surrounded by high-signal areas (respectively 0.8 . 1.5 and $2 \mathrm{~mm}$ ) (lig. $9 \mathrm{a}-\mathrm{b}$ ). On corresponding T2-weighted images the lesions appeared as small superficial defects (fig. $9 \mathrm{c}$-d). On the same slices two large defects were visualized. These lesions were precisely delineated by intraarticular fluid. appearing bright on $\mathrm{T} 2$-weighting.

Therefore MRI allowed easy detection of all the lesions that were surgically created.

\section{CONCLUSION}

Until now, the comparative advantages of $\mathrm{CT}$ and MRI regarding the alignment of the patella have not been demonstrated.

Computed tomography following arthrography appears to be a relatively invasive but valuable tool in the assessment of retropatellar cartilage, but this diagnostic modality appears less advantageous MRI.

Eariy chondral lesions, as well as assoc abnormalities of the menisci, ligaments. tendons, are easily detected on MRI wit exposing the patient to ionizing radiation. More the development of new techniques such as : sequences, is improving the evaluation of cartilage.

We consider the 3-dimensional analysis, usit image processing system and rapid imz techniques, to be the best method. It allows I reconstruction in every plane from a volume $\mathrm{mm}$ thick slices.

Despite the current limitations, such as cos! availability of the apparatus, we believe that will become the method of choice in investigation of knec-joint pathology.

\section{REFERENCES}

1. BOVEN F., BELLEMANS M.A., GEURT POTVLIEGE R. A comparative study of pateilo-femoral joint on axial roentgenogram. arthrogram, and computed tomography foll anthrography. Skel. Radiol., 1982. 8, 183.185.

2. BOVEN F.. DE BOECK M.. LEEMAN POTVLIEGE R. Computed tomography of the joint in double contrast. J. belge Radiol., 198 429.435.

3. CROSBY EB, INSALL L. Recurrent dislocation patella. J. Bone Joint Surg., 1976, S8-d, 9-13.

4. DELGADO-MARTINS N. A study of the pe of the patella using computerized tomog J. Bone Joint Surg- 1979, 61-B. 443-444.

5. DOWD G. BENTLEY G. Radiographic assessmi patellar instability and chondromalacia pa J. Bone Joint Surg - 1986, 68. B, 297.300.

6. IHARA H. Double-contrast $C T$ arthrography cartilage of the patellofemoral joint. Clin. Or 1985. 198. 50-55. 
INSALL. J., FALVO K., WISE D. Chondromalacia patellac. J. Bone Joint Surg.. 1976, 58-A, 1-8. JACKSON D., JENNINGS L., MAYWOOD R., BERGER P. Magnetic resonance imaging of the knee. Am. J. Sports Med., 1988, 16, 29.37. HANEK P. BAKER L., SARTORIS D., NEUMANN C., RESNICK D. MR Arthrography : Anatomic-pathologic investigation. Radiology. 1987. 163. 141-147.

GYLYS-MORIN V., HAJEK P., SARTORIS D., RESNICK D. Articular cartilage defects. Detectability in cadaver knees with MR. Am. J. Radiol., 1987, 148. 1153-1157.

MANSAT C., BONNEL. F., JAEGER 1. L'appareil cotenseur du genou. Ed. Musson, Paris 1985.

MERCHANT A., MERCER R., JACOBSEN R., COOL C. Roentgenographic analysis of patellofemoral congruence. J. Bone Joint Surg., 1974, S6-A. 1391.1396.

MINK J., REICHER M.. CRUES J. FOX J. MRI of the knee. Ed. Raven Press, New York, 1987.

LAURIN C.. LEVESQUE H., DUSSAULT R.. LABELLE H., PEIDES J. The abnormal lateral patellofemotal angle. J. Bone Joint Surg., 1978. $60 \cdot$ A. $55 \cdot 60$.
15. SHAHABPOUR M., OSTEAUX M. In : Sintzoff S.. Osteaux M. Imagerie du genou. Ed. Masson, Paris. 1989.

16. WOTTYS E.. WILSON M., BUCKWALTER K., BRAUNSTEIN E. MARTEL W. Magnetic resonance imaging of knee hyaline cartilage and intraarticular pathology. Am. J. Sports Med., 1987, 15, $455-463$.

17. YULISH B., MONTANEZ J., GOODFELLOW D., BRYAN P. MULOPULOS G., MODIC M. Chondromalacia patellae : Assessment with $M R$ Imaging. Radiology, 1987, 164, 763-766. 



\title{
Chondral Lesions of the Patella Evaluated with Computed Tomography, Magnetic Resonance Imaging, and Arthroscopy
}

Frank Handelberg, M.D., Maryam Shahabpour, M.D., and Pierre-Paul Casteleyn, M.D.

\begin{abstract}
Summary: In a small series of cadaver knees, experimentally created lesions of the patellar cartilage were compared using contrast computed tomography (CT) and magnetic resonance (MR) imaging. Contrast $C T$ was able to recognize only $50 \%$ of the lesions smaller than $3-\mathrm{mm}$ diameter at the first attempt, and none of the lesions of $0.8 \mathrm{~mm}$. MR imaging detected all the lesions, even those as small as $0.8 \mathrm{~mm}$, without use of contrast material. Simultaneously, a prospective clinical study comparing MR diagnoses of chondral lesions with arthroscopic findings was initiated in a series of 54 knees. This clinical study revealed that, concerning patellar chondral lesions, the accuracy of MR imaging compared with arthroscopy (the gold standard) was $81.5 \%$. The sensitivity was $100 \%$, but the specificity only $50 \%$ due to the false positives. Reexamination of the MR records enabled us to refine the MR diagnosis and to propose a staging of the chondral lesions. The high rate of false-positive results in our series can be explained by the hypothesis that MR imaging can possibly detect very early lesions, which appear as abnormalities in the deep cartilage layers. Key Words: Contrast computed tomography-Magnetic resonance imagingPatellar cartilage.
\end{abstract}

In the early 1980s, papers were published on computed tomography (CT) scanning of the knee joint. Using the double-contrast technique, the patellar cartilage could be clearly visualized. Various authors have studied the congruity and alignment, the regularity of the contour, the penetration of contrast material in fissures and ulcerations, and the thickness of the cartilage $(1-6)$. All this could be assessed without having superpositions as in arthrograms, and without knee flexion.

For a few years, magnetic resonance (MR) imaging has appeared as a revolutionary technique in the investigation of human joints. The advantages of

Department of Orthopaedics and Traumatology (F.H.) and Department of Radiology (M.S., P.-P.C.). Academic Hospital. Vruje Universiteit Brussel, Brussels, Belgium

Address correspondence and reprint requests to Dr. F. Handelberg, Department of Orthopaedics, A.Z.-V.U.B., Laarbeeklaan 101, B-1090 Brussels, Beigium. this method include absence of ionizing radiation and use of contrast material, and multiplanar imaging capabilities without any manipulation of the knee. The excellent soft-tissue contrast allows the delineation of meniscal and ligamentous structures.

On the other hand, only a few authors reported findings concerning cartilage defects $(7-12)$. Wojtys et al. studied lesions created on the patella and condyles of cadaver knees, as well as arthroscopically confirmed lesions in patients (13). Their study revealed that MR imaging was able to detect most of the lesions $\geqslant 4 \mathrm{~mm}$ in width and $3 \mathrm{~mm}$ in depth.

To detect small 2-mm defects, Gylys-Morin et al. used intraarticular gadolinium-diethylenetriamine pentaacetic acid as contrast material in a cadaveric study (14). They concluded that intraarticular fluid is necessary for the delineation of focal defects.

To date, we have found no published study comparing MR imaging and the CT double-contrast 
technique. We decided to correlate both methods in a small series of cadaver knees.

Simultaneously, a prospective clinical study was initiated in which MR diagnoses of chondral lesions were compared with arthroscopic findings.

\section{MATERIAL AND METHODS}

\section{Experimental Study}

On fresh cadaver knees, drill holes of different sizes and depths were surgically performed. The diameter of the drill holes ranged from 0.8 to $5 \mathrm{~mm}$ and the depth from I to $2 \mathrm{~mm}$. The knees were completely removed, with hermetically closed joint capsules, leaving a few milliliters of saline in the joint, simulating normal synovial fluid.

MR imaging without contrast injection, followed by $C T$ examination with contrast injection, were performed. MR signals were generated by a 1.5-T magnet (Magnetom, Siemens, Erlangen, Germany), using $T 2$ spin-echo pulse sequences with 3 mm-thick contiguous slices $(\mathrm{TR}=2,500 \mathrm{~ms}, \mathrm{TE}=$ 22 and/or $80 \mathrm{~ms}$ ). CT was performed using the double-contrast technique and a high-resolution program with a Somatom DRG (Siemens). The scans were taken using $x$-rays of $125 \mathrm{kV}$ and $45 \mathrm{~mA}$ amperes; the slice width was $2 \mathrm{~mm}$ with an increment of $2 \mathrm{~mm}$; exposure time was $5 \mathrm{~s}$.

$C T$ and MR images were then analyzed and compared, each by a single observer who knew the presence of the lesions, but not their number and exact location on the patella.

\section{Clinical Study}

A series of 53 young patients (representing 54 knees) presenting with knee pain without clear clinical diagnosis was examined with MR before undergoing arthroscopy. Most of the patients complained of diffuse knee pain, but neither history nor clinical examination was clearly indicative of meniscal or chondral lesion. Although the examiners had a strong clinical impression of organic knee pathology, this pathology did not, in their opinion, require an immediate arthroscopy. The age range was 12-66 years with a mean age of 33 years. There were 30 men and 23 women (sex ratio-3:2). In all patients $\mathrm{T} 2$ spin-echo pulse sequences were used in the sag. ittal plane (3-mm-thick contiguous slices, TR = $2,100 \mathrm{~ms}, \mathrm{TE}=22$ and/or $80 \mathrm{~ms}$ ). We completed the examination by an axial view with $T 2$ pulse sequence in 38 cases. A three-dimensional fast sequence (FISP) was performed in the sagittal plane (1-mm-thick slices. $\mathrm{TR}=30 \mathrm{~ms}, \mathrm{TE}=10 \mathrm{~ms}$, flip angle $=40^{\circ}$ ) in the 16 other cases; this pulse se. quence allowed axial and coronal reconstructions.

The validity of the correlation was based on a complete arthroscopic examination, with probing of all the intraarticular eiements.

The classification of Ficat and Hungerford was used to describe the chondral lesions (15). The results of the MR examinations were known by the surgeons before arthroscopies, which were performed by the authors in 44 cases, and by skilled arthroscopists of the Brussels area in the 10 other cases.

\section{RESULTS}

The cadaver study showed that large lesions of 3 . and 5 -mm diameter were easily seen on contrast CT, but $50 \%$ of the 1.5 and $2 \mathrm{~mm}$ lesions were missed on a first examination. All the 1.5 - and $2-\mathrm{mm}$ lesions could be detected only after a second attempt. The $0.8-\mathrm{mm}$ holes were not recognized at all.

In contrast, MR imaging without contrast allowed easy detection of all experimentally created lesions, even the smallest. Figure I shows a T2-weighted image showing three small superficial defects that measured $0.8,1.5$, and $2 \mathrm{~mm}$, respectively. On the contiguous slice, two larger defects of 3 and $5 \mathrm{~mm}$ are visualized on the medial facet (Fig. 2). These lesions are precisely delineated by intraarticular fluid appearing bright on $\mathrm{T} 2$.

Looking at the results of the clinical study, on a total of 54 knees, lesions of the patellar cartilage were reported on 44 MR examinations. Only 34 of

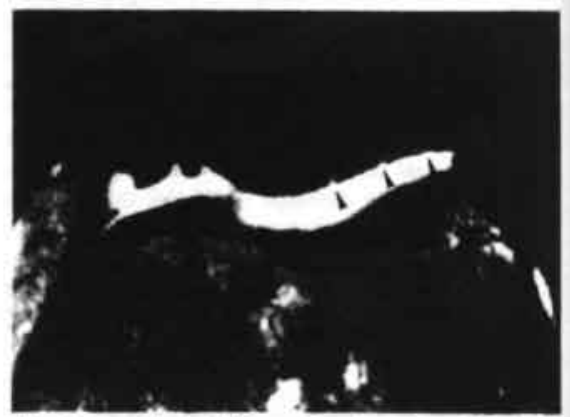

FIG. 1. T2-weighted axial image of a cadaver knee (TR $=2,500$ $\mathrm{ms}, \mathrm{TE}=\mathrm{B0} \mathrm{ms}$ ). Three small lesions (arrowheads) are seen on the lateral facet of the patella. They measure, respectively, from medial to tateral, 2. 1.5, and $0.8 \mathrm{~mm}$ in diameter. 

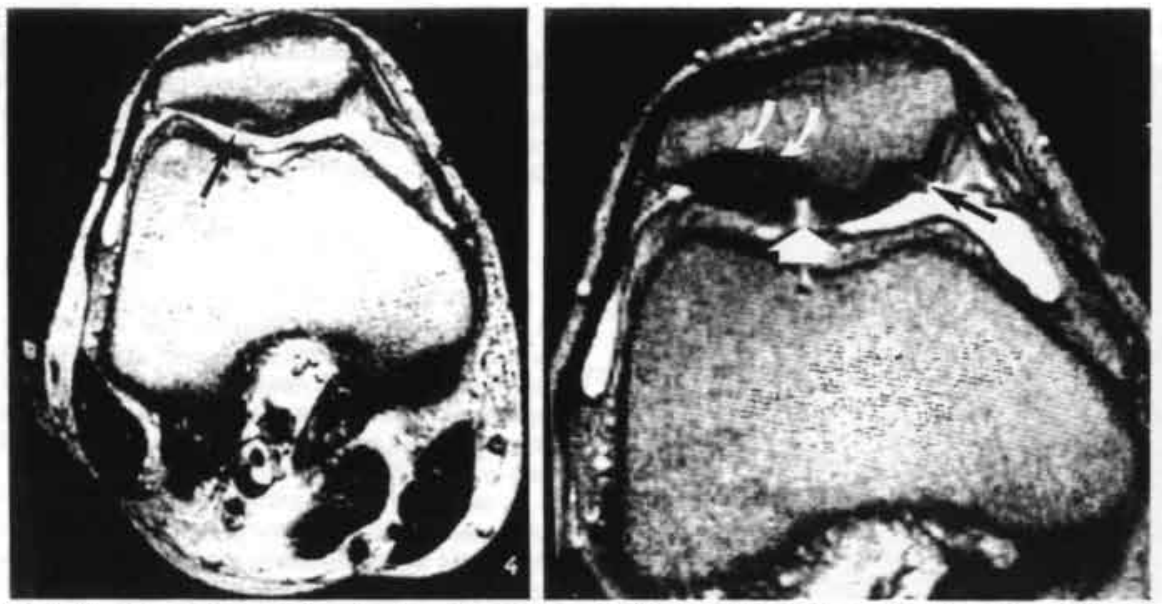

FIG. 4. These T2-weighted axial slices show the patellar cartilage outlined by joint fluid of high signal intensity, (TR $=2,500$ ms, TE $=80$ ms). A: A superficial fissuration is seen on the first section (arrow). This is a stage II lesion. B: On the adjacent slice, a deep ulceration is indicated by the large white arrow (stage III lesion). In the cartilage of the medial facet, there is a thin defect with a smalt nap lesion (black arrow). Note the low-signal area of subchondral sclerosis (small white arrows) on the lateral facet.
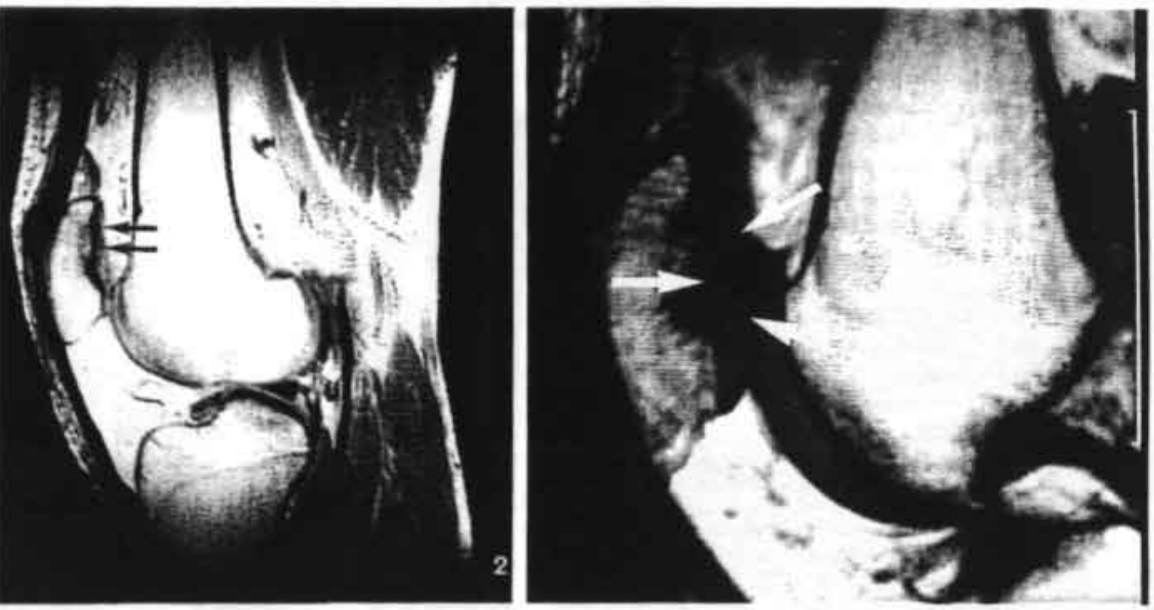

FIG. 5. A: Stage IV lesion (sagittal section, TR $=2,200 \mathrm{~ms}$, TE $=22 \mathrm{~ms}$ ). Thinning of the patellar cartilage and inhomogeneity of signal intensity (arrows) in a degenerative knee. B: This normal and intact patellar cartilage (arrows) exemplifies the lesion seen in (A) Tl.weighted image (sagittal plane, TR $=800 \mathrm{~ms}, \mathrm{TE}=15 \mathrm{~ms}$ ). 
10. Mink JH, Reicher MA, Crues JV III. Fox JM. Magnetic resonance imaging of the knee. New York: Raven Press. 1987.

II. Shahabpour M, Osteaux M. In: Sintzoff S, Osteaux M, eds. Imagerie du genou. Imagerie par resonance magnetique. Paris: Masson. 1989:94-123.

12. Yulish B, Montanez 1, Goodfellow D. Bryan P. Mulopulos G. Modic M. Choodromalacia patellae: assessment with MR imaging. Radiology 1987;164:763-6.

13. Wojtys E, Wilson M, Buckwalter K, Braunstein E, Martel W. Magnetic resonance imaging of knee hyaline cartilage and intraarticular pathology. Am J Sports Med 1987;15:45s 63.

14. Gylys-Morin V. Hajek P, Sartoris D, Resnick D. Artich cartilage defects. Detectability in cadaver knees with M0 AJR 1987:148:1153-7.

15. Ficat RP. Hungerford DS. Disonders of the patello-feman joint, Chondrosis and Arthrosis, chp. 12, pp. 194-232. B6 timore: Williams \& Wilkins, 1977.

16. Konig $\mathrm{H}$, Aicher KP. MRI evaluations of cartilage and $m$ niscal disorders of the knee: a comparison with ultrasoun scintigraphy and CT. Hospimedica 1988:6:49-59. 


\section{IRM DU CARTILAGE COMPARAISON IRM ARTHROSCOPIE, à propos de 320 cas}

M. SHAHABPOUR, C. TEBACHE, P.P. CASTELEYN, F. HANDELBERG. G.B. LEROUX, F. MACHIELS, M. DE MAESENEER, M. OSTEAUX

Akademisch Ziekenhuis van de Vrije Universiteit Brussel AZ.VUB - 101. Laarbeeklaan - 1090 Bruxelles-Belgique Tel. : 32247752 94/fax: : 322.477 .52 .96

Si l'IRM permet de visualiser directement le cartilage de manière non invasive, ses performances diagnostiques sont encore très controversées en ce qui concerne la détection précoce de lésions cartilagineuses patello-trochléennes et surtout fémoro-tibiales.

Le problème principal provient de l'absence de consensus sur la ou les séquences d'acquisition optimale(s) à utiliser.

De nombreuses études cliniques $(2-5,6-$ $7,9-11,13-14,16,18-20,23-24)$ et expérimentales sur cadavres $(1,12,15,17$. 21,22 ) ont été effectuées durant ces 10 dernières années. Ces études portent sur un nombre limité de cas et utilisent des techniques différentes (séquences écho de spin T1, T2, T2 rapide, T1 avec injection intraveineuse ou intraarticulaire de contraste, écho de gradient avec acquisition 3D (GRASS, spoiled-GRASS avec suppression de la graisse...), séquences avec transfert de magnétisation,...)
Depuis avril 1987, nous avons effectué plus de 10000 examens IRM de genoux, en utilisant de façon systématique, des séquences écho de spin T2 classiques puis ultérieurement rapides (avec coupes de densité protonique) dans les 3 plans de l'espace, complétées dans certains cas par des séquences écho de gradient avec acquisition 3D FISP ou DESS (GRASS) pondérées $\mathrm{T}^{*}$ et FLASH (spoiledGRASS SPGR) avec suppression du signal de la graisse, pondérées TI.

L'étude suivante a pour objectifs de déterminer prospectivement la précision diagnostique des séquences écho de spin $\mathrm{T} 2$ dans la détection des lésions cartilagineuses patello-trochléennes et fémorotibiales et de rechercher (rétrospectivement) des signes IRM permettant de mieux caractériser les différents stades arthroscopiques (I à IV selon la classification de FICAT). 


\section{MATERIELS ET METHODES}

320 examens IRM ont été prospectivement corrélés aux résultats de l'arthroscopie.

Les patients (205 hommes, 115 femmes) d'âge moyen de 34 ans avec des extrêmes allant de 16 à 72 ans présentaient tous un syndrome de dérangement interne du genou.

L'examen IRM est réalisé de façon systématique en coupes sagittales écho de spin $\mathrm{T} 2$ et en coupes coronales et axiales écho de spin T2 (classique puis ultérieurement rapide, à deux échos), sur un appareil Siemens avec un champ magnétique de 1.5 ou de 1 Tesla.

Pour l'écho de spin T2 classique, le temps de répétition est de $2400 \mathrm{msec}$, les temps d'écho de respectivement 20 et 80 msec; pour l'écho de spin T2 rapide, le temps de répétition est de $4700 \mathrm{msec}$ et les temps d'écho de respectivement 20 et $95 \mathrm{msec}$, l'épaisseur des coupes étant de $3 \mathrm{~mm}$ dans tous les cas. Les images sont réalisées avec un champ de vue moyen de $180 \mathrm{~mm}$ pour les coupes sagittales et de 200 pour les coupes axiales et une matrice moyenne de 256 sur 160 points avec une seule acquisition.

L'examen est toujours interprété par le même radiologue sur écran et sur film, avec comparaison systématique des coupes de densité protonique (premier écho) et des coupes pondérées T2. L'intervalle maximum entre I'IRM et l'arthroscopie est de deux mois.

L'arthroscopie a été effectuée par deux orthopédistes spécialistes du genou et systématiquement illustrée par un schéma indiquant le stade et la localisation exacte des lésions. (Schéma 1)

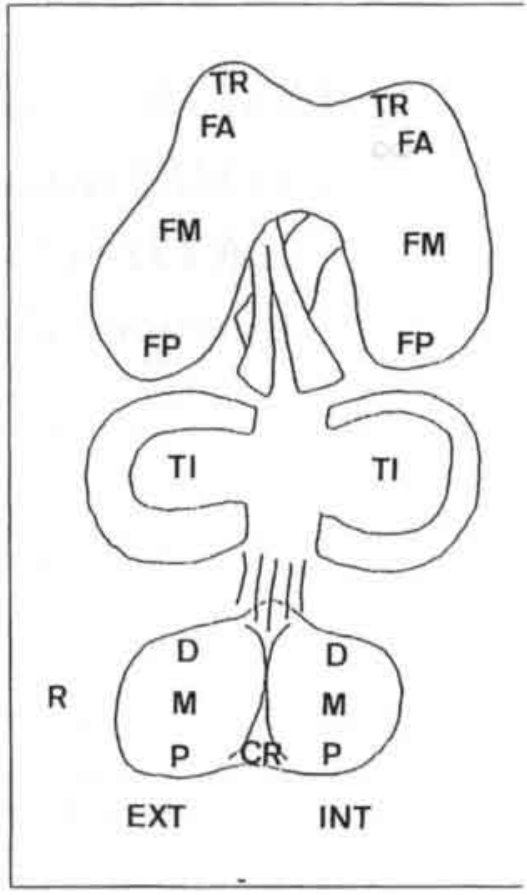

TR: trochlede

FA : condyle fémoral antérieur

FM: condyle fémoral moyen

FP: condyle fémoral postérieur

$T I$ : plateau tibial

$A$ : rotule

(D : distal; $M$ : moyen; $P$ : proximal)

CA : crête rotulienne

EXT: externe

INT : interne

Les chirurgiens étaient au courant du dia gnostic IRM et de la localisation de: lésions décrites; ceci était inévitablı puisque l'IRM était réalisée dans le bu préciser un diagnostic clinique incertain

Nous avons utilisé la classification IRN de Yulish (24), un peu modifiée :

- Stade I : épaississement focal du carti lage avec hyposignal en T2 (ler et 2, 


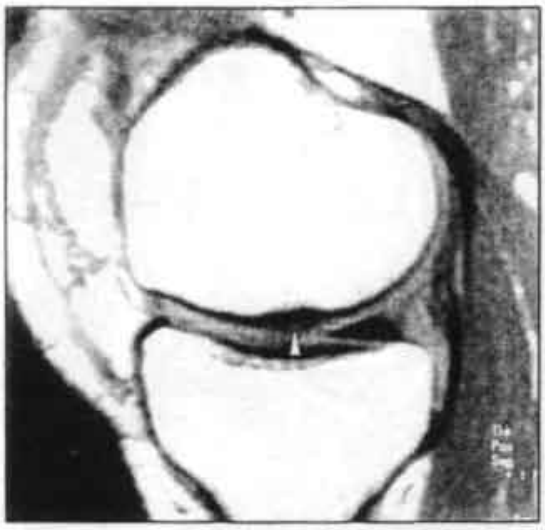

a
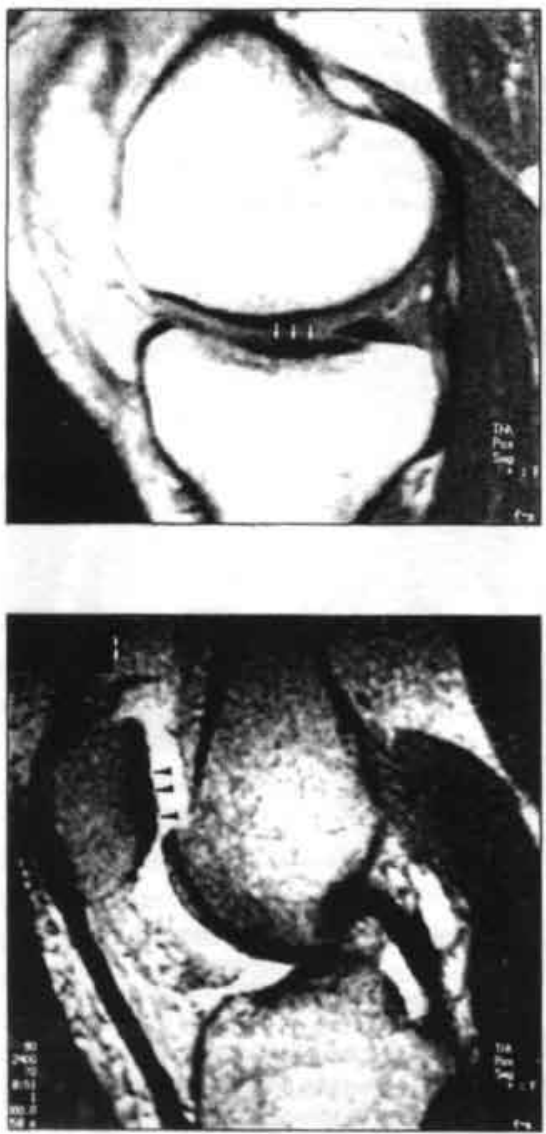

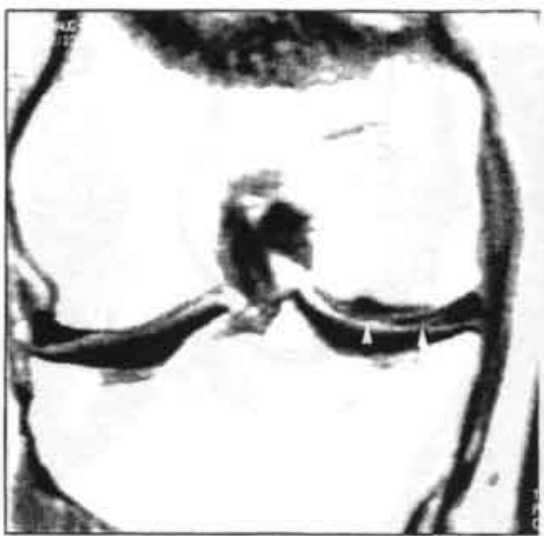

b

Figure 3

Chondropathie de stade I du condyle fémoral interne et du plateau tibial interne (à l'arthroscopie).

L'atteinte fémorale est suspectée sur les coupes sagittale (a) et coronale (b) sous forme d'un épaississement focal du cartilage et de l'os sous-chondral (têtes de flèche), de signal faible en densité protonique $(a: 2400 / 20 ; b: 4700 / 19)$.

Par contre, la lésion tibiale n'a pas été décrite prospectivement sur les coupes IRM: de discrètes hétérogéneités de signal sont décelées à posteriori (c, petites flèches). Présence d'un flap horizontal au niveau des cornes postérieure et moyenne du ménisque interne (b, flecche).

\section{Figure 4}

Chondropathie rotulienne de stade II (à l'arthroscopie).

La coupe sagittale pondérée T2 (2400/70) montre des petites irrégularités de surface au niveau de la facette rotulienne interne près de la créte (têtes de flèches) 


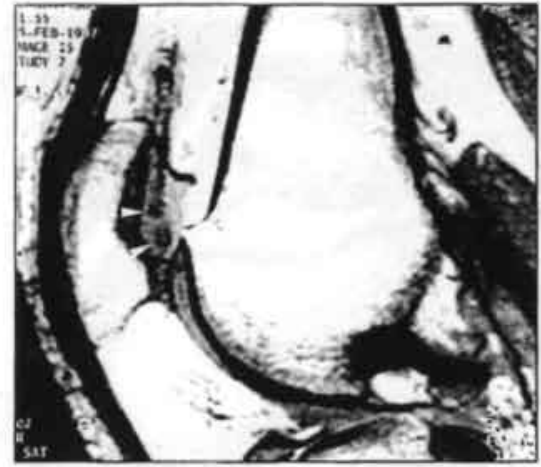

a

\section{c}

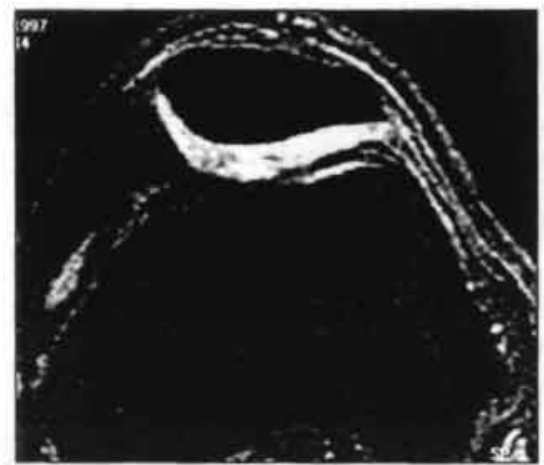

stade de chondropathie en utilisant le nombre de sites avec le stade décrit et confirmé par l'arthroscopie. Elle est de $100 \%$ pour les lésions patello-trochléennes de stade III et IV (avec 3 vrais positifs pour le stade IV, 13 vrais positifs pour le stade III). Elle est de $89.6 \%$ pour les lésions patello-trochléennes de stade II (avec 104 vrais positifs). Elle n'est que de $52.3 \%$ pour les lésions patello-trochléennes de stade I (avec 22 vrais positifs).

Le nombre de sites de chondropathies qui n'est pas correctement classifié par 48 I'IRM, est considéré comme le nombre

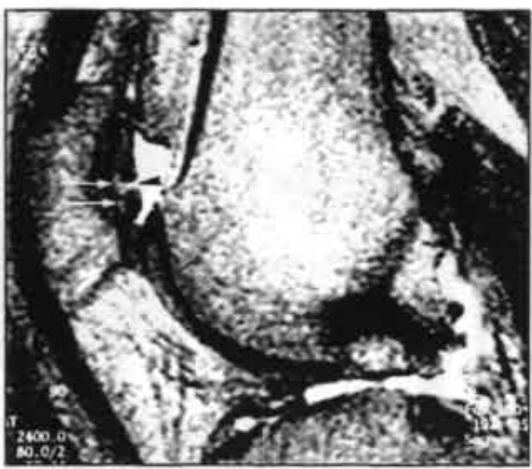

b

Figure 6

Fissure cartilagineuse rotulienne post-traumatique (chondropathie fissuraire ouverte) avec hypersignal lineiaire parallèle à l'os sous-chondral (flèches) et prolongement transversal (tête de flèche noire), de signal intense en $T 2$ ( $b: 2400 / 80)$. Sur la coupe de densité protonique (a : 2400/20), présence de zones arrondies de signal faible autour de la zone fissuraire (tétes de flèche blanches). Sur la coupe axiale fine (2 $\mathrm{mm}$ d'épaisseur) réalisée en séquence écho de gradient pondérée $T 1$ avec acquisition $3 D$ et suppression de la graisse (c: $\left.60 / 10 / 60^{\circ}\right)$, la fissure n'est pas visible; on ne décèle qu'une discrète hétérogéneité du signal intracartilagineux et de petites irrégularités de contour.

de faux négatifs (nombre de sites avec IRM négative alors qu'il y a une lésion). Nous n'avons pas trouvé de faux négatifs pour les lésions patello-trochléennes de stades III et IV; nous avons 12 faux négatifs pour le stade II et 20 faux négatifs pour le stade $\mathrm{I}$.

La spécificité est le pourcentage des sites normaux à I'IRM dans la population des sites effectivement normaux. Elle est déterminée en utilisant le nombre de sites pour lequel le stade IRM n'est pas confirmé par l'arthroscopie. Le nombre de faux positifs est le nombre de sites ayant une IRM positive alors qu'il n'y a pas de 


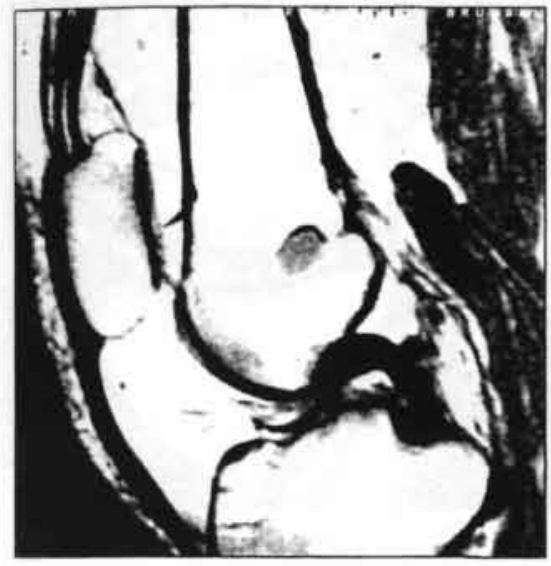

a

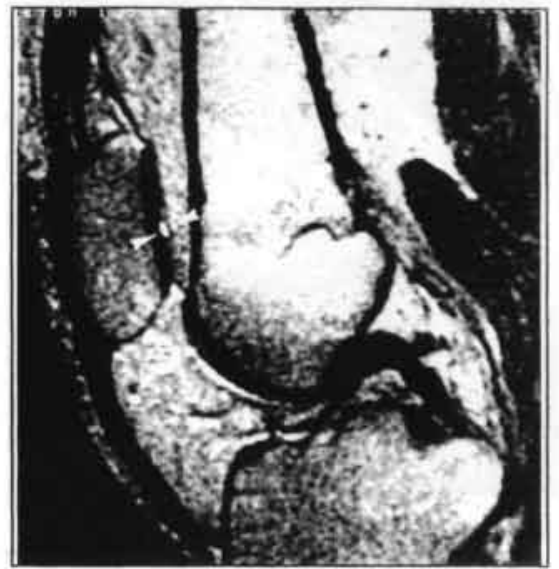

b

Figure 7

Chondropathie rotulienne de stade arthroscopique II à III Les coupes sagittales écho de spin T2 (a : 2400/20; $b: 2400 / 70)$ montrent une petite zone superficielle de signal anormal, augmenté en densité protonique (a), intense en T2 (b), au niveau de la facette interne (têtes de flèche).

lésion. La spécificité est de $100 \%$ pour les chondropathies patello-trochléennes de stades III et IV (pas de faux positifs). Elle est de $96.3 \%$ pour celles de stade II (19 faux positifs) et de $87.2 \%$ pour celles de stade I ( 76 faux positifs). Le nombre élevé de faux positifs s'explique en partie par le fait que tout hétérogénéité du signal cartilagineux, même quand elle n'était visible que sur les coupes de densité protonique, était considérée comme suspecte de chondropathie (de stade I), ceci dans le but de pousser le chirurgien à décrire l'état du cartilage rotulien sur son compte rendu.

Le nombre de sites considérés comme normaux à l'arthroscopie et le nombre de sites avec un stade arthroscopique différent du stade IRM est le nombre de vrais négatifs : il est de 637 pour les lésions patello-trochléennes de stade IV, 627 pour celles de stade III, 505 pour celles de stade II et 522 pour celles de stade I.
Enfin, la précision de l'IRM (qui est le pourcentage de patients bien classés) pour la détection des chondropathies patello-trochléennes est de respectivement $100,100,95$ et $85 \%$ pour les stades IV à I.

La valeur prédictive positive (VPP) est le nombre de sites présentant effectivement une lésion par rapport au nombre total de sites avec IRM positive. Elle est de $100 \%$ pour les stades III et IV, de 84.5 pour le stade II et très faible (22.4) pour le stade I.

La valeur prédictive négative (VPN) est le nombre de sites n'ayant effectivement pas de lésion par rapport au nombre total de sites avec IRM négative. Elle est très élevée pour tous les stades ( $100 \%$ pour les stades III et IV, 97.6 pour le stade II et 96.3 pour le stade I).

Pous les localisations fémoro-tibiales, le taux de sensibilité est de $100 \%$ pour les stades III et IV, les taux de spécificité et 


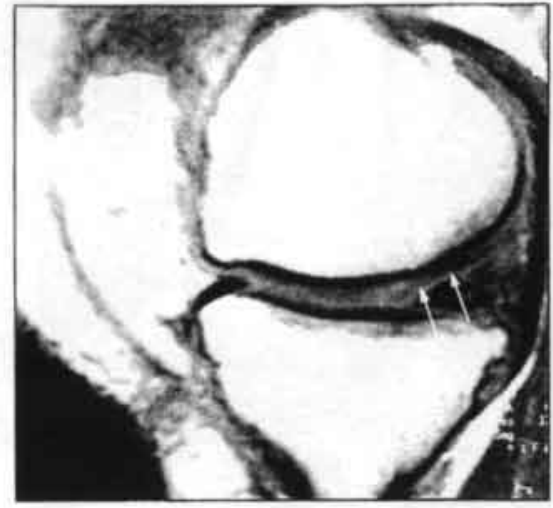

a

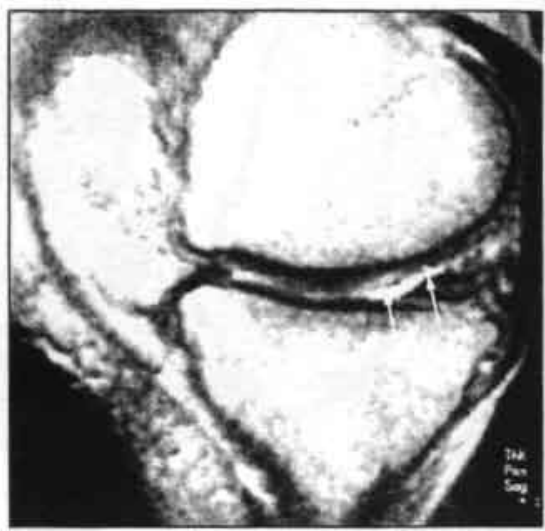

b

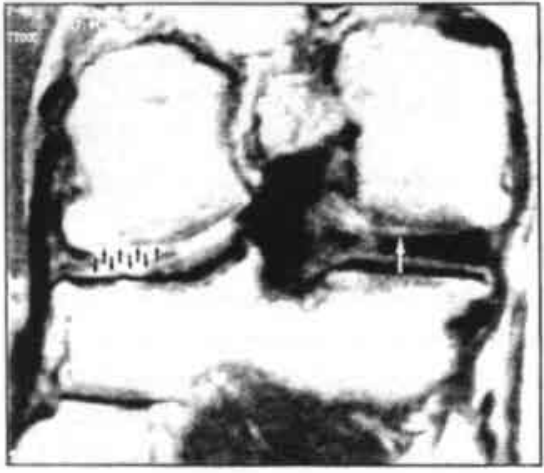

c

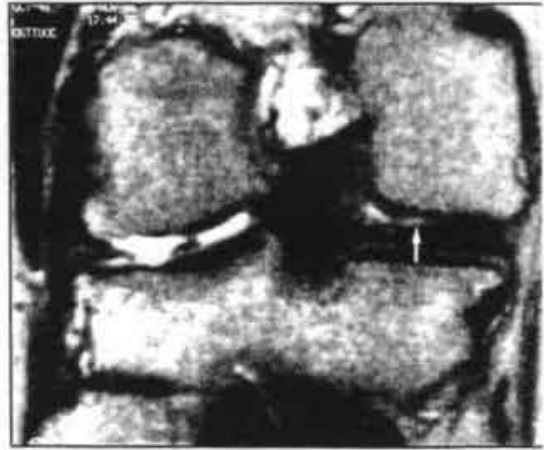

$\boldsymbol{d}$

Figure 8

Lésions cartilagineuses de stade II à III au niveau des deux compartiments fémoro-tibiaux.

Sur les coupes sagittales écho de spin T2 (a : 2400/20, b:2400/70). le cartilage fémoral présente un signal hétérogène et des contours irréguliers avec des zones d'amincissement focal (flèches).

Les coupes coronales écho de spin T2 rapide (c: 4700/19, d: 4700/93)

montrent lamincissement chondral et sous-chondral très important

50 de la portion externe du condyle fémoral et du plateau tibial externe (petites flèches).

Le condyle fémoral inteme présente une zone de signal intense (flèche)

et un aspect focalement irreggulier de l'os sous-chondral (têtes de flèche). 


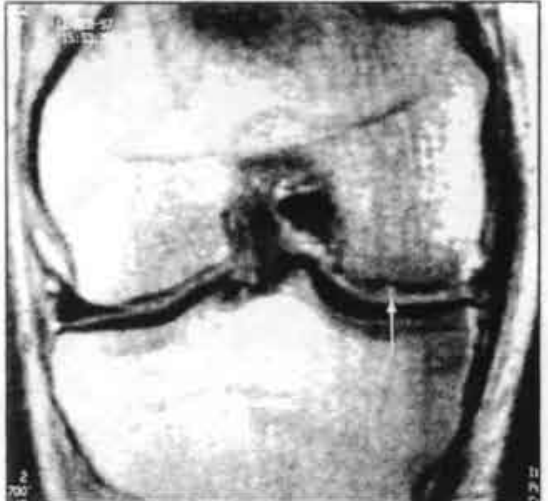

a

Figure 10

Petite ulcération cartilagineuse profonde du condyle fémoral interne chez un sportif qui a subi une méniscectomie interne quelques mois auparavant et présente un gonflement douloureux du genou depuis la reprise des sports. Interruption focale du cartilage avec pénétration de liquide synovial de signal intense (flèche) sur les deux échos de la séquence $T 2$ rapide (a : 4700/19, b : 4700/93) obtenue dans le plan coronal. Une coupe coronale fine de $1,5 \mathrm{~mm}$ d'épaisseur obtenue en séquence écho de gradient $T 2^{\prime}$ avec acquisition $3 D$, sur l'aimant de 1 Tesla (c : $28 / 9 / 40^{\circ}$ ) montre de façon nette que le défect est profond avec mise à nu de l'os sous-chondral (tête de flèche). Cette séquence permet de mettre en évidence une réaction d'hyperostose sous-chondrale focale gräce aux effets de susceptibilité magnétique (petites flèches).

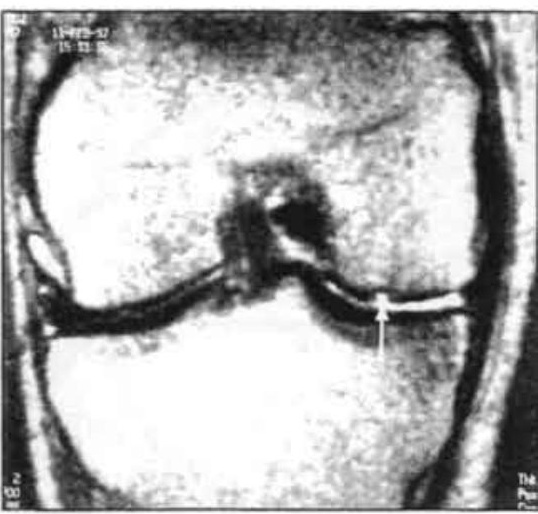

b

c

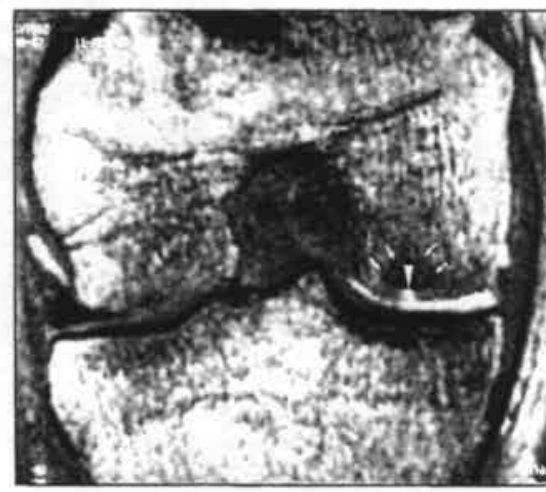

résultats étaient globalement de $100 \%$ pour la sensibilité, $50 \%$ pour la spécificité et $81.5 \%$ pour la précision.

- Mac Cauley et al (14) ont évalué les rotules de 52 patients en coupes axiales de $5 \mathrm{~mm}$ d'épaisseur, en séquence écho de spin $\mathrm{T} 2$ et ont déterminé rétrospectivement une sensibilité de $86 \%$, une spé- cificité de $74 \%$ et une précision de $81 \%$

- Brown et al (3) ont étudié les rotules dt 75 patients en coupes axiales, en séquen ce écho de spin T2 et ont obtenu une sen sibilité de $91 \%$, une spécificité de $88 \%$ et une précision de $89 \%$ pour les stade III a IV et des taux insuffisants pour le stades débutants. 


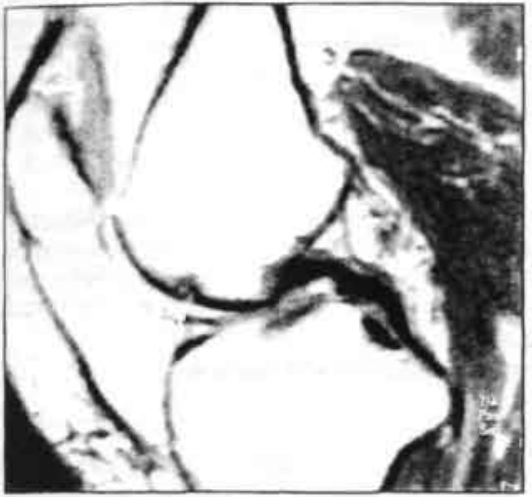

a

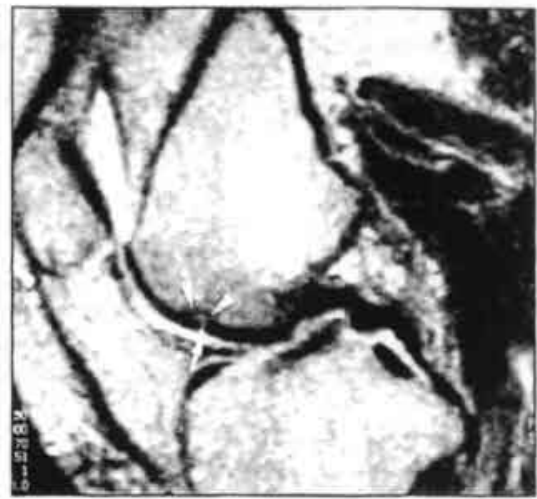

b

Figure 11

Chondropathie probable de la partie antérieure du condyle fémoral interne (non décrite à l'arthroscopie).

Les coupes sagittales écho de spin T2 $(a: 2400 / 20 ; b: 2400 / 70)$ meftent en évidence une zone d'interruption du contour chondral et sous-chondral (flèche), de signal augmenté, associée à une réaction sous-chondrale focale (têtes de flèches).

Ce cas illustre le fait que les rapports arthroscopiques ne sont pas toujours fiables à $100 \%$, même quand ils sont détaillés.

\begin{tabular}{|c|c|c|c|c|}
\hline$\%$ & Sensibilité & Spécificité & Précision & Corrélation \\
\hline $\begin{array}{l}\text { Yulish } 87 \\
19 \text { rotules } \\
X-Z ; 4 \mathrm{~mm}\end{array}$ & & & & $11 / 12$ (II-III) \\
\hline $\begin{array}{l}\text { Shahab pour } 90 \\
54 \text { rotules } \\
X+Z ; 3 \mathrm{~mm}\end{array}$ & 100 & 50 & 81.5 & \\
\hline $\begin{array}{l}\text { Mc Cauley } 92 \\
52 \text { rotules } \\
Z ; 3 \mathrm{~mm}\end{array}$ & 86 & 74 & 81 & \\
\hline $\begin{array}{l}\text { Brown } 93 \\
75 \text { rotules } \\
\mathrm{Z}: 3 \mathrm{~mm}\end{array}$ & 91 & 88 & 89 & (III-IV) \\
\hline $\begin{array}{l}\text { Valloton } 95 \\
33 \text { rotules } \\
\mathrm{Z} ; 3 \mathrm{~mm}\end{array}$ & 84.7 & 97.2 & 91.6 & \\
\hline
\end{tabular}




\begin{tabular}{|l|r|r|r|r|r}
\hline & & & Stades & \\
\hline Sites & 1 & II & III & IV & Total \\
\hline Rolule & 33 & 112 & 8 & 2 & 155 \\
Trochlée & 9 & 4 & 5 & 1 & 19 \\
Condyles fémoraux & 76 & 144 & 8 & 3 & 183 \\
Plateaux tibiaux & 71 & 101 & 7 & 4 & 10 \\
\hline Total & 189 & 361 & 28 & 58 & 5 \\
\hline
\end{tabular}

Tableau II

Répartition et sévérité des lésions cartilagineuses en arthroscopie

\begin{tabular}{|c|c|c|c|c|c|}
\hline Stades & Sensibilité & Spécificité & Précision & VPP & VPN \\
\hline I & 32.2 & 78.3 & 71.5 & 20.5 & 87 \\
\hline II & 88.8 & 91.3 & 93.5 & 80 & 95.4 \\
\hline III & 100 & 99.9 & 99.8 & 96.4 & 100 \\
\hline
\end{tabular}

Tableau III

Taux de corrélation IRM-arthroscopie (en \%)

Résultats globaux sans distinction de localisation des lésions.

\begin{tabular}{|c|c|c|c|c|c|c|}
\hline Stades & Sites & Sensibilité & Spécificité & Précision & VPP & VPN \\
\hline \multirow[t]{2}{*}{1} & Rotule et trochiée & 52.3 & 87.2 & 85 & 22.4 & 96.3 \\
\hline & Surfaces Fémoro-tibiales & 26.5 & 67.5 & 58.1 & 19.5 & 75.5 \\
\hline \multirow[t]{2}{*}{ ॥ } & Rotule et trochlée & 89.6 & 96.3 & 95.1 & 84.5 & 97.6 \\
\hline & Surfaces fèmoro-tibiales & 88.5 & 84.5 & 86 & 77.9 & 92.2 \\
\hline \multirow[t]{2}{*}{ III } & Rotule et trochlée & 100 & 100 & 100 & 100 & 100 \\
\hline & Surfaces fémoro-tibiales & 100 & 99.8 & 99.8 & 93.7 & 100 \\
\hline \multirow[t]{2}{*}{ IV } & Rotule et trochiée & 100 & 100 & 100 & 100 & 100 \\
\hline & Surtaces fémoro-tibiales & 100 & 100 & 100 & 100 & 100 \\
\hline
\end{tabular}

Tableau IV

Taux de correlation IRM-arthroscopie (en \%)

\begin{tabular}{|l|c|c|c|c|}
\hline & Sensibilité & Spécificité & Précision & Stades \\
\hline Shahab pour 97 & 52.3 & 87.2 & 85 & I \\
320 rotules & 89.5 & 96.3 & 95.1 & II \\
X-Y:3 mm & 100 & 100 & 100 & III-IV \\
\hline
\end{tabular}




\begin{tabular}{|l|c|c|c|c|}
\hline & Sensibilité & Spécificité & Précision & Stades \\
\hline Colin 94 & 47 & 95.5 & 72.5 & \\
37 patients & & & & \\
X. Y: $3 \mathrm{~mm}$ & & & & \\
& 26.5 & 67.5 & 58.1 & 1 \\
Shahab pour 97 & 88.5 & 84.5 & 86 & II \\
320 patients & 100 & 99.9 & 99.9 & III-IV \\
X. Y: $3 \mathrm{~mm}$ & & & \\
\hline
\end{tabular}

Tableau VI

Taux de corrélation IRM-Arthroscopie (en \%) pour les lésions fémoro-tibiales

- Colin et al (4) ont examiné 37 patients en coupes sagittales et coronales, en séquence écho de spin $\mathrm{T} 2$ et ont conclu que seules les chondropathies fémorotibiales évoluées (avec mise à nu de l'os sous-chondral) sont bien visualisées. (Tableau VI)

- Vallotton et al (23) ont réalisé une étude de corrélation IRM-arthroscopie chez 33 patients, en utilisant des coupes axiales de $3 \mathrm{~mm}$ d'épaisseur, en séquence écho de spin T2 et ont obtenu des scores de sensibilité et de spécificité beaucoup plus élevés que les auteurs précédents (sensibilité globale de $84,7 \%$, spécificité de $97,2 \%$ et précision de $91,6 \%$ ).

Les études suivantes ont étudié les taux de corrélation IRM-arthroscopie pour les séquences avec suppression de la graisse. - Rose et al (19) ont étudié les rotules de 71 patients en coupes axiales épaisses de 4 à $5 \mathrm{~mm}$, en séquence écho de spin T2 ou T2 rapide à deux échos avec suppression de la graisse. Ils ont obtenu une sensibilité de $72 \%$, une spécificité de $88 \%$, une précision de $79 \%$ (cette dernière ne différant pas substantiellement des études n'utilisant pas les séquences avec suppression de la graisse).

- Broderick et al (2) ont réalisé des coupes sagittales de $4 \mathrm{~mm}$ d'épaisseur en séquence écho de spin $\mathrm{T} 2$ rapide à deux échos avec suppression de la graisse, chez 13 patients arthrosiques qui ont subi ultérieurement une arthroscopie; ils ont déterminé de bons taux de corrélation.

- Gagliardi et al (9) ont étudié les rotules de 27 patients en coupes axiales fines de $3 \mathrm{~mm}$, en séquence écho de spin T2 et en séquence SPGR 2D avec suppression de la graisse: ils ont obtenu des taux de sensibilité plus élevés pour les séquences écho de spin que SPGR 2D avec suppression de la graisse mais de nombreux faux positifs avec les séquences écho de spin $\mathrm{T} 2$.

- Recht et al (18) ont examiné le cartilage fémoro-patellaire de 41 patients avec des coupes axiales de 2 à $2,5 \mathrm{~mm}$ d'épaisseur, en séquence SPGR 3D avec suppression de la graisse et ont détecté des lésions cartilagineuses avec une sensibilité de $81 \%$, une spécificité de $97 \%$ et une précision de $97 \%$. Ils n'ont cependant pu détecter que 6 des 13 lésions débutantes $(2 \mathrm{~A})$ avec cette technique.

- Disler et al (7) ont comparé IRM et arthroscopie chez 48 patients examinés à l'aide de coupes sagittales de $3 \mathrm{~mm}$ d'épaisseur en écho de spin T2 et de coupes sagittales et de reconstructions axiales fines de $1.5 \mathrm{~mm}$ d'épaisseur en séquence SPGR 3D avec suppression de 
la graisse. Des coupes axiales ont également été réalisées en séquence écho de spin $\mathrm{T} 2$ rapide à deux échos dans 26 cas. Ils ont obtenu des taux de sensibilité sensiblement plus élevés pour la séquence SPGR 3D avec suppression de la graisse que pour la séquence écho de spin T2.

D'après les résultats de notre étude, la séquence écho de spin T2 (avec coupes de densité protonique) permet une évaluation satisfaisante de nombreuses lésions cartilagineuses.

Sur la séquence écho de spin T2, le cartilage normal apparaît homogène et de contour régulier. Il présente un signal intermédiaire (gris) sur les coupes de densité protonique et uniformément faible (noir) sur les coupes pondérées T2. L'os sous-chondral est noir et d'épaisseur variable sur les coupes de densité protonique. Sur les coupes pondérées $\mathrm{T} 2$, il est indistinguable du cartilage. L'os médullaire a un signal intense en densité protonique, faible en $\mathrm{T} 2$ (deuxième écho).

Le liquide a un signal intermédiaire en densité protonique, intense sur le premier écho de la séquence $\mathrm{T} 2$ rapide et intense sur le deuxième écho de la séquence T2 (classique ou rapide). Il existe donc un contraste élevé entre le contour cartilagineux et le liquide sur les coupes pondérées T2 et entre le cartilage et l'os souschondral sur les coupes de densité protonique.

Les coupes de densité protonique (premier écho) ont un rapport signal/bruit élevé. Elles donnent une idée de l'épaisseur du cartilage; elles montrent certaines anomalies de contour, certaines anomalies de signal et des remaniements de l'os sous-chondral. Elles permettent une neuses, à condition de tenir compte des hétérogénéités de signal dues aux diffé. rentes couches du cartilage articulaire normal et à des artéfacts propres à la séquence écho de spin $\mathrm{T} 2(15,17,21)$. Les coupes pondérées T2 (deuxième écho) mettent en évidence les défects cartilagineux remplis de liquide synovial, certains remaniements du signal cartilagineux, sous-chondral et intramédullaire. Lorsque le cartilage n'est pas directement visualisé, dans toute son épaisseur (comme c'est le cas au niveau des condyles fémoraux), on peut rechercher des signes indirects d'atteinte cartilagineuse, tels que des irrégularités d'épaisseur de l'os sous-chondral.

Les images écho de spin pondérées T2 ont un score de faux positifs relativement élevé (9). Les résultats sont, à notre avis, améliorés lorsqu'on combine les coupes pondérées $\mathrm{T} 2$ et les coupes de densité protonique, ces dernières donnant une évaluation un peu moins faussée de l'épaisseur cartilagineuse, surtout en séquence écho de spin T2 rapide.

D'autre part, dans cette étude, les images de densité protonique et pondérées $\mathrm{T} 2$, sont examinées sur écran et comparées systématiquement pour chaque position de coupe, ce qui, à notre avis, améliore la détection des lésions.

Les taux de corrélation particulièrement élevés de cette étude sont vraisemblablement dues aussi à la grande expérience des images écho de spin $T 2$ puisque nous les utilisons systématiquement depuis plus de 10 ans (sur plus de 10000 genoux). Ces images présentent, en effet, par rapport aux séquences plus adaptées au cartilage (SPGR 3D avec suppression de la graisse...), l'avantage d'offrir des informations anatomiques additionnelles, par exemple l'étude des ménisques dans 
le plan axial, la confirmation de souris articulaires, l'évaluation du tendon rotulien dans le plan axial...

Une limitation importante de la séquence écho de spin T2 est l'absence de contraste entre le cartilage et la graisse préfémorale en ce qui concerne l'articulation fémoro-patellaire ou entre les deux surfaces cartilagineuses d'une articulation, en l'absence de réaction liquidienne focale. Un bon contraste cartilage-graisse peut être obtenu grâce aux séquences SPGR 3D avec suppression de la graisse, ce que nous pratiquons actuellement en l'absence de réaction liquidienne dans l'espace fémoro-patellaire (6).

Bien que I'arthroscopie ait été utilisée comme standard de référence dans cette étude, cette procédure a des limites potentielles pour la détection de défects cartilagineux $(6,19)$ (Figures 1, 11). Celles-ci comprennent la difficulté de déterminer la profondeur d'un défect lorsque l'os sous-chondral n'est pas mis à nu et la difficulté de détecter des lésions intracartilagineuses lorsque la surface cartilagineuse apparaît intacte; leur évaluation est limitée à la palpation. Or, si dans les atteintes dégénératives du cartilage, les remaniements débutent habituellement à la surface cartilagineuse, les lésions post-traumatiques peuvent léser les couches profondes sans nécessairement atteindre la surface du cartilage. Les lésions peuvent apparaître sous forme d'un hypersignal linéaire parallèle à l'os sous-chondral sur les coupes pondérées T2 (16). Ce type de lésion peut, au stade débutant, être méconnu par l'arthroscopie à l'inspection de la surface articulaire.

En conclusion, d'après cette étude de corrélation arthroscopique, les séquences écho de spin T2 classiques et rapides à deux échos permettent de classifier de manière fiable les anomalies cartilagineuses de stade II à IV.

Les taux de corrélation sont insuffisants pour les lésions cartilagineuses de stade 1, en particulier pour les localisations fémoro-tibiales.

Remerciements à Filip Vamhoenacker. Filip De Ridder et Willy Baumens pour leur aide da la collecte et au traitement des dossiers et à Amn De Viaene pour la réalisation du mamuscrit.

\section{BIBLIOGRAPHIE}

1-ADAM G., NOLTE-ERNSTING C., PRESCHER A.

Experimental Hyaline Cartilage Lesions: Two-dimensional Gradient-Echo MA Imaging JMRI, 1991, 1, 665-672.

\section{2 - BRODERICK L.S., TURNER D.A., RENFREW D.L. ET AL. \\ Severity of articular cartilage abnormality in patients with osteoarthritis: evaluation with fast spin-echo MR vs arthroscopy A.JA 1994, $162: 99-103$}

3-BROWN T.R., QUINN S.F.

Evaluation of Chondromalacia of the patellofemoral compartment with axial magnetic resonance imaging Skeletal Radiology. 1993, 22, 325-328.
4 - COLIN T., PROVOST N., BEGUIN J., LOYAU G. Contribution of magnetic resonance imaging to the evaluation of femorotibial cartilage lesions

Rev. Phum. [Engl. Ed.], 1994, 61 (5), 297-302

5 - DE SMET A.A., MONU J.U.V., FISHER D.A. Signs of Patellar Chondromalacia on Sagittal T2. weighted Magnetic Pesonance Imaging Skeletal Radiology, 1992, 21, 103-105.

6 - DISLER D.G., MCCAULEY T.R., WIRTH C.R. ET AL.

Detection of knee hyaline cartilage defects using fal-suppressed three-dimensional spoiled gradientecho MR imaging : comparison with standard MR imaging and correlation with arthroscopy AJP 1995, 165, 377-382 
7 - DISLEA D.G., MC CAULEY T.A., KELMAN C.G. ET AL.

Fat-suppressed three-dimensionat spoiled gradient-echo MA imaging of hyaline cartilage defects in the knee : comparison with standard MA imaging and arthroscopy

A.JP $1996,167,127 \cdot 132$

8 - FICAT R.P., HUNGERFOAD D.S.

Disorders of the patello-femoral joint

Baltimore, Williams and Wilkins eds, 1977,194-232

9 - GAGLIARDI J.A., CHUNG E.M., CHANDNANI V.P. ET AL.

Detection and Staging of Chondromalacia Patellae :

Relative Elficacies of Conventional MR Imaging. MR

Arthrography and CT Arthrography

A.JP $1994,163,629-636$

10- HANDELBERG F., SHAHABPOUR M.,

CASTELEYN P.P.

Chondral Lesions of the Patella Evaluated

with Computed Tomography, Magnetic

Resonance Imaging and Arthroscopy

The Journal of Arthroscopic and Related Surgery.

$1990,6,24-29$.

11- HARDY P.A., RECHT M.P., PIRAINO D. ET AL. Optimatization of a dual echo in the steady

state (DESS) free-precession sequence

for imaging cartilage

JMAI 1996, 6,329-335

12 - HODLER J., BERTHIAUME M.J., SCHWEITZER M.E.

Knee Joint Hyaline Cartilage Defects : A comparative Study of MR and Anatomic Sections

J CAT 1992, 16, 597-603.

13 - KRAMER J., RECHT M.P., IMHOF H. ET AL.

Pastcontrast MR arthrography in assessment

of cartilage lesians

JCAT $1994,18,218-224$

14 - MCCAULEY T.R., KIER R., LYNCH K.J.

Chondromalacia Patellae : Diagnosis with MR Imaging A.JA 1992, 158, 101-107.

15 - MODL J.M., SETHER L.A., HAUGHTON V.M.

Articular Cartilage : Correlation ol Histologic Zones with Signal Intensity at MA Imaging

Padiology 1991, 181, 853-855

16 - PETERFY C.G., GENANT H.K.

Emerging application of magnetic resonance imaging in the evaluation of articular cartilage

Radiol Clin North Am 1996, 34, 195-213
17 - RECHT M.P., KRAMER J., MARCEL.IS S. Abnormalities of Articular Cartilage in the Knee : Analysis of Available MR Techniques Radiology 1993, 187, 473-478.

18 - RECHT M.P., PIRAINO D.W., PALETTA G.A. Accuracy of Fat-suppressed Three-dimensional Spoiled Gradient-Echo FLASH MA Imaging in the Detection of Patellofemoral Articular Cartilage Abnormalities Padiology 1996,198,209-212.

19 - ROSE P.M., DEMLOW T.A., SZUMOWSKI J., QUINN S.F.

Chondromalacia Patellae : Fal-suppressed MR Imaging

Radiology 1994, 193,437-440

20 - REISER M.F., BONGARTZ G., ERLEMANN R. Magnetic Resonance in Cartilaginous lesions of the knee joint with three-dimensional gradient-echo imaging

Skeletal Radiology 1988,17,465-471

21 - RUBENSTEIN J.D., KIM J.K., HENKELMAN R.M.

EHfects of compression and recovery on bovine articular cartilage : appearance of MA images Padiology 1996, 201,843-850

22 - SEO G.S., AOKI J., MORIYA H., KARAKIDA O., SONE S., HIDAKA H., KATSUYAMA T.

Hyaline cartilage : in vivo and in vitro assessment with magnetization transfer imaging

Radiology 1996, 201,525-530

23 - VALLOTTON J.A., MEULI R.A., LEYVRAZ P.F., LANDRY M.

Comparison between magnetic resonance imaging and arthroscopy in the diagnosis of patellar cartilage lesions

Knee Surg. Sports Traumatol. Arthroscopy. $1995,3,157-162$

24 - YULISH B.S., MONTANES J., GOODFELLOW D.B.

Chondromalacie Patellae : Assessment with MA Imaging

Radiology 1987, 164, 763-766. 


\section{Management of $\mathrm{ACL}$ injuries}

A. Non-operative management of anterior cruciate ligament injuries in the general population

B. ACL management : an analysis of medium and long term results 


\title{
NON-OPERATIVE MANAGEMENT OF ANTERIOR CRUCIATE LIGAMENT INJURIES IN THE GENERAL POPULATION
}

\author{
PIERRE-PAUL CASTELEYN. FRANK HANDELBERG
}

From the Vrije Universiteit Brussel, Brussels, Belgium

The operative treatment of lesions of the anterior cruciate ligament (ACL) in athletes has been widely advocated and performed. We have investigated the outcome of non-operative management in a lower-demand, general population. We reviewed a consecutive group of 228 patients, which excluded professional and high-level athletes, for two to 12 years after an ACL lesion had been diagnosed by arthroscopy.

There was a low incidence of secondary ACL and meniscal surgery, $5.4 \%$ and $3.5 \%$ respectively, and all these procedures were performed during the first three years after the ACL injury.

We studied a subgroup of 109 patients with follow-up of at least five years (mean 8.5 years) and evaluated them using the IKDC score. The general outcome was reasonably satisfactory, with $23 \%$ in grade $A, 50 \%$ in grade $B, 21 \%$ in grade $C$ and only $6.4 \%$ in grade D. We found no statistically significant prognostic effect within this group as regards age, activity levels, or the incidence of associated lesions.

\section{$J$ Bone Joint Surg (Br) 1996;78-B:446-51.}

Received 25 Augusi 1995; Accepted after revision 29 November 1995

Lesions of the anterior cruciate ligament (ACL) in athletes have been studied extensively in orthopaedic sports medicine, and operative treatment using grafts is widely advocated for this particular group of patients (Fetto and Marshall 1980; Noyes et al 1983a; Kannus and Järvinen 1987; Andersson et al 1989; Barrack et al 1990; Daniel and Fithian 1994). Many ACL lesions, however, are seen in non-athletes as a result of accidents or low-grade recrea-

P.P. Casteleyn, MD, Professot, Department of Human Anatomy and Associate Clinical Professor, Department of Orthopaedics and Traumatology

F. Handelberg, MD, Assistant Clinical Professor

Department of Orthopaedies and Traumatology, Academisch Ziekenhuis, AZ.VUB Laarbeekiaan 101, B-1090 Brussels, Belgium.

Correspondence should be sent to Professor P.-P. Casteleyn.

O1996 British Editorial Society of Bone and Joint Surgery $0301-620 \times 196 / 31176 \$ 2.00$ tional activities (Jain, Swanson and Murdoch 1983; Caste leyn, Handelberg and Opdecam 1988).

We aimed to investigate the outcome of the conservativ treatment of ACL lesions in a lower-demand population.

\section{PATIENTS AND METHODS}

Over a period of 12 years, we managed a total of 27. patients with acute traumatic knee haemarthrosis. All ha examination under anaesthesia and arthroscopy.

Of these, we treated 46 by ACL reconstruction. The included patients with gross or multidirectional joint laxin (grade-3 or grade-4 pivot shift, combined lesions of th $\mathrm{ACL}$ and lateral collateral ligament (LCL) or posterio cruciate ligament (PCL)) and in addition all high-level a professional athletes. These 46 cases (16.8\%) were exclo ded from the study group.

This left a consecutive group of 228 patients (83\%) wh were managed conservatively. There was an almost fou fold male to female ratio and the mean age at the time of injury was 33.2 years ( 16 to 66 ). The main causes of injur were daily living activities $(28.1 \%)$, traffic accident (11.8\%), and recreational activities $(60.1 \%)$ (Table 1).

Initial management. In $83 \%$ of the cases, arthroscopi evaluation was within three weeks of the index injury. Th: proportions of isolated ACL ruptures and those associate with meniscal and ligamentous lesions were comparabi with those reported in previous studies (Casteleyn et: 1988) (Tables I and II); only 21 of the ACL tears (9\%) we partial. Intrasynovial $\mathrm{ACL}$ lesions $(14 ; 6.1 \%)$ were left: much as possible within the synovial sheath. There wz spontaneous partial reattachment of the distal $\mathrm{ACL}$ sturs to the PCL in 18 knees $(7.9 \%)$ : these were left undisturbe Some ACL remnants which seemed likely to imping between the femur and tibia and limit extension we trimmed. No reconstructive ACL surgery was performo during the initial arthroscopy.

Meniscal surgery was performed if indicated and fo sible. Three of 27 tom lateral menisci and 17 of $105 \mathrm{medi}$ menisci were sutured. Minor lesions, of one lateral a seven medial menisci, were left untreated. All other meni cal lesions $(77.1 \%$ of the medial and $85.2 \%$ of the later meniscal lesions) were treated by partial arthroscop. meniscectomy. No surgery was performed for medial 00 lateral ligament (MCL) lesions.

All patients were treated by a comprehensive rehabilit 
Table L. Details of the whole series and of the subgroups with secondary ACL and meniscal surgery

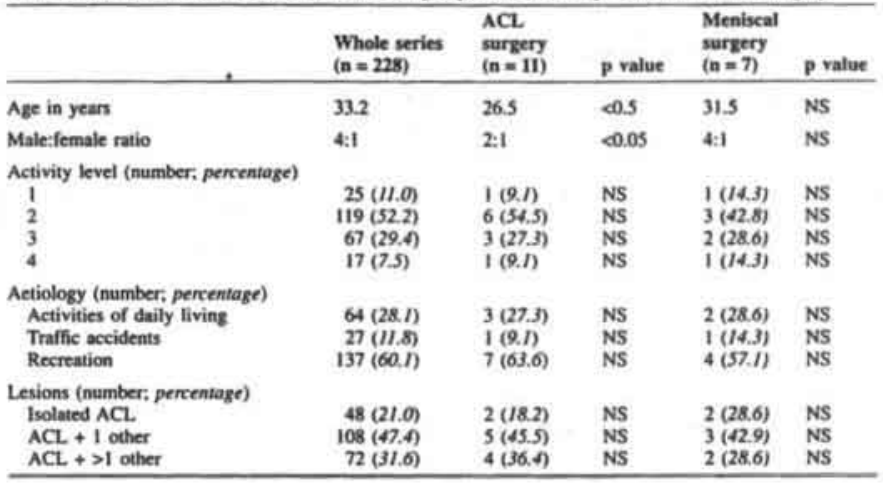

Table II. Lesions diagnosed during initial arthroscopy

\begin{tabular}{lcl}
\hline Lesions & Number & Percentage \\
\hline Eolated ACL & 48 & 21.05 \\
$\mathrm{ACL}+1$ other & 108 & 47.37 \\
$\mathrm{ACL}+>1$ other & 72 & 31.58 \\
$\mathrm{ACL}+$ medial meniscus & 105 & 46.05 \\
+ lateral meniscus & 27 & 11.84 \\
+ medial collateral ligament & 64 & 28.07 \\
+ lateral collateral ligament & 15 & 6.58 \\
+ posterior cruciate ligament & 0 & 0.0 \\
\hline
\end{tabular}

tion programme for six to eight weeks. Early weightbearing was allowed with the eventual protection of a cast or a brace in cases of partial $\mathrm{ACL}$ and intrasynovial $\mathrm{ACL}$. $\mathrm{MCL}$ and $\mathrm{LCL}$ lesions.

Follow-up. The initial 228 patients have been followed up for 2 to 12 years. Data were collected during annual examinations or by written questionnaire or telephone interviews. Of these patients, 25 (11\%) have been lost to follow-up leaving 203 with known results at over two years. Records were maintained of pre- and postinjury levels of activity and of the reasons for any long-term modification of the level of activity.

We classified activity levels into four groups:

1) strenuous activity which included jumping, pivoting and cutting (soccer):

2) moderate activity, involving heavy manual work (skiing. tennis);

3) light activity such as jogging or running: and

4) sedentary activity such as housework and the normal activities of daily living.

We recorded all subsequent surgery for the ACL lesion (intra-articular or extra-articular) and all subsequent meniscal surgery. These data were then used to construct survival tables with ACL or meniscal surgery or both considered as end-points. The age, gender, activity level, aetiology of the injury and any associated lesions in the patients who required secondary $\mathrm{ACL}$ and/or meniscal surgery were then compared with similar data from the patients who had no subsequent operations (Table I).

We tried to review all 132 patients with at least five years' follow-up for their subjective opinion, clinical examination, and radiological assessment. Of these, $23(17 \%)$ refused further clinical and radiological examination. The 109 patients who were studied in detail did not differ significantly from the initial cohort as regards mean age. gender, or distribution of activity level. cause of injury or associated lesions. The mean period from the initial injury was 8.5 years ( 5 to 12). The final assessment was recorded on the International Knee Documentation form (Hefti et al 1993). This assesses results in seven separate subgroups (see Table IV). These are subjective assessment, symptoms, range of motion, ligament examination (which in our study included use of the KT 2000 tester (Medmetric Corporation. San Diego, California) with $134 \mathrm{~N}$ displacement force), compartmental crepitus, radiography and a one-leg hop test. The result in each subgroup is scored on a fourpoint scale. The lowest grade determines the global grade of the subgroup, and the worst evaluation group determines the final score.

We tried to find correlations between the final grade and age at injury, associated lesions. activity level or modification and length of follow-up, using the analysis of variance, the paired $t$-test, and the Mann-Whitney $U$ test.

\section{RESULTS}

Survival. Only 11 of the 203 patients followed for two to 12 years had needed secondary ACL surgery $(5.4 \%)$ and seven had secondary meniscal surgery (3.5\%) (Table I). All these procedures had been performed during the first three years after the index injury with none later than this. These 


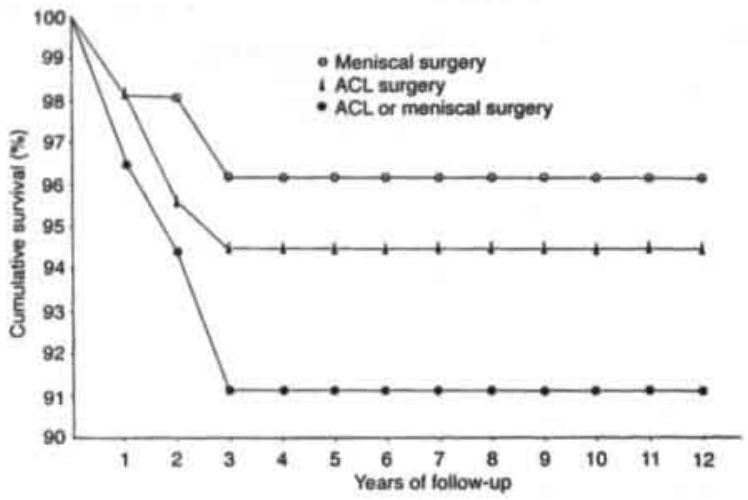

Fig. 1

Survival curves after non-operative management of $\mathrm{ACL}$ injuries, using as end-points secondary $\mathrm{ACl}$ surgery, secondary meniscal surgery, and both together. figures give a high survival rate which persists for three to 12 years (Fig. 1).

We found no correlation between survival and cause of injury, associated lesions or activity levels, but the patients who had needed subsequent ACL surgery were younger and had a lower male-to-female ratio (Table I).

Activity levels. The initial activity levels were those of a general population with a fair proportion of manual workers, some of them involved in moderate sport and recreational activities (Table 1). None of the patients who needed secondary $\mathrm{ACL}$ and meniscal surgery had modified their activity level since the injury and its treatment. Less than half of all the patients had modified their activity levels after the ACL injury (Table III) and of those who reported a decrease, only 57 (65.5\%) considered that this decrease in activity level was related to their $\mathrm{ACL}$ injury.

Table IIL. Activity level modification after $\mathrm{ACL}$ injury in 203 patients

\begin{tabular}{lcc}
\hline & Number & Perentage \\
\hline Increase of I level & 4 & 2.0 \\
No modification & 112 & 55.2 \\
Decrease & & \\
1 level & 39 & 19.2 \\
2 level & 20 & 9.9 \\
3 level & 28 & 13.8 \\
\hline
\end{tabular}

As expected, the relationship between decrease in activity level and the original injury became less important with length of follow-up. Any decrease in activity was reported to be injury-related by $78 \%$ when it occurred less than five years after injury, by $57 \%$ between five and eight years, and by only $17 \%$ when it occurred after more than eight years.

IKDC examination. The results in 109 patients are sumnarised in Table IV. The subjective results were satisfac- tory: $82.4 \%$ of the patients stated that their knee was normal or nearly normal. This was confirmed by the rather benign nature of the symptoms; $61 \%$ achieved a normal grade and $21 \%$ a nearly normal grade. The range of motion was marginally limited in only $19 \%$, with no important extension or flexion deficits. The lowest grades were found as expected in the KT 2000 ligament examination subgroup, but even for this test $32.1 \%$ of the knees had a nearly normal grade. As regards compartmental crepitus $84 \%$ were normal and there was no radiological narrowing of the joint space in $76 \%$.

For the one-leg hop test, $57 \%$ had normal rates; this confirmed the low intensity of any symptoms and the reasonably good function of most of the knees. The overall evaluations gave $23 \%$ in grade $A, 50 \%$ in grade $B, 21 \%$ in grade $C$ and $6.4 \%$ in grade $D$.

We could find no prognostic correlation between age at the time of injury, associated lesions, activity level at time of injury and at time of evaluation, and the final evaluation grade. There was no marked decrease in evaluation grades with increasing length of follow-up (Fig. 2).

\section{DISCUSSION}

The results of our study must be analysed with caution, since $11 \%$ of the patients were lost to follow-up, and $17 \%$ of the patients whom we traced at over five years refused further clinical examination. The main strength of our work is that the population of patients was selected at the time of the initial injury: many previous studies of the non-operative management of $\mathrm{ACL}$ injuries were based on patients who were seeking further treatment because of significant complaints (Fetto and Marshall 1980; McDaniel and Dameron 1980; Giove et al 1983; Noyes et al 1983a; Finsterbush et al 1990).

The conservative management which we used during the 14 years of the study must be considered in relation to the 
Table IV. IKDC evaluation of 109 patients. The numbers in bold type are the global results for each group (see lext)

\begin{tabular}{|c|c|c|c|c|c|c|c|c|}
\hline \multirow[b]{3}{*}{ Group } & \multicolumn{8}{|l|}{ Grade } \\
\hline & \multicolumn{2}{|l|}{$\mathbf{A}$} & \multicolumn{2}{|l|}{ B } & \multicolumn{2}{|l|}{ C } & \multicolumn{2}{|l|}{ D } \\
\hline & Number & Percentage & Number & Percentuge & Number & Percentage & Number & Pereentage \\
\hline Subjective assessment & 33 & 303 & 57 & 52.3 & 18 & 16.5 & 1 & 0.9 \\
\hline Function & 33 & 30.3 & 55 & 50.5 & 21 & 19.3 & 0 & \\
\hline Impact on activity & 38 & 34.9 & 56 & 5t.4 & 14 & 12.8 & 1 & 0.9 \\
\hline Symptoms & 67 & 61.5 & 23 & 21.1 & 14 & 12.8 & 5 & 4.5 \\
\hline Pain & 88 & 80.7 & 14 & 12.8 & 6 & 5.5 & 1 & 09 \\
\hline Swelling & 98 & 89.9 & 6 & 5.5 & 4 & 3.6 & 1 & 0.9 \\
\hline Partial giving-way & 70 & 64.2 & 22 & 20.2 & 13 & 11.9 & 4 & 3.7 \\
\hline Full giving-way & 93 & 85.3 & 10 & 9.1 & 6 & 5.5 & 0 & \\
\hline Range of motion & 88 & 80.7 & 21 & 19.2 & 0 & & 0 & \\
\hline Extension lack & 97 & 88.9 & 12 & 11.0 & 0 & & 0 & \\
\hline Fexion lack & 104 & 95.4 & 5 & 4.5 & 0 & & 0 & \\
\hline Ligament examination & 35 & 32.1 & 52 & $\$ 7.7$ & 21 & 19.2 & 1 & 0.9 \\
\hline Lachmann & 60 & 55.0 & 48 & 44.0 & 1 & 0.9 & 0 & \\
\hline End-point & 91 & 83,4 & & 18 & 165 & & & \\
\hline $70^{\circ}$ drawer & 65 & 59.6 & 39 & 35.8 & 5 & 4.6 & $\mathbf{0}$ & \\
\hline Medial joint opening & 40 & 36.7 & 64 & 58.7 & 4 & 3.7 & I & 0.9 \\
\hline Lateral joint opening & 97 & 89.0 & 12 & 11.0 & & & 0 & \\
\hline Pivot shift & 39 & 35.8 & 53 & 48.6 & 16 & 14.7 & 1 & 0.9 \\
\hline Crepitus & 93 & 85.3 & & & 15 & 13.8 & 1 & 0.9 \\
\hline Patellofemoral & 104 & 95.4 & & & 4 & 3.7 & i & 0.9 \\
\hline Medial compartment & 98 & 89.9 & & & 11 & 10.1 & 0 & \\
\hline Lateral compartment & 107 & 98.1 & & & 2 & 1.8 & 0 & \\
\hline Joint narrowing (radiological) & 83 & 76.2 & & & 21 & 19.3 & 5 & 4.6 \\
\hline Medial & 84 & 71.1 & & & 20 & 18.4 & 5 & 4.6 \\
\hline Lateral & 95 & 87.2 & & & 13 & 11.9 & 1 & 0.9 \\
\hline Patellofemoral & 87 & 79.8 & & & 18 & 16.5 & 4 & 3.7 \\
\hline Hop test & 63 & 57.8 & 40 & 36.7 & 4 & 3.7 & 2 & 1.8 \\
\hline Final evaluation & 25 & 22.9 & 54 & $\$ 9.5$ & $\mathbf{2 3}$ & 21.1 & 7 & 6.4 \\
\hline
\end{tabular}

evolving knowledge on ligament healing; some of our earliest patients were treated during the early 1980 s. We would not now use casting for ligament sprains or partial ruptures of the ACL (Daniel et al 1994).

Our review of a general patient population, less interested in sporting activities, also means that precise data about physical activity are more difficult to obtain. The IKDC assessment form does not offer the same refinement of analysis as the Tegner score, but seems to be more applicable to this type of population. It should also be noted that the mean time between injury and latest radiological examination in our 103 patients ( 8.5 years: 5 to 12 ) may be too short to show significant degenerative changes in this lowdemand population.

The most surprising result of our study was the fairly limited laxity shown by ligament examination; only $44.9 \%$

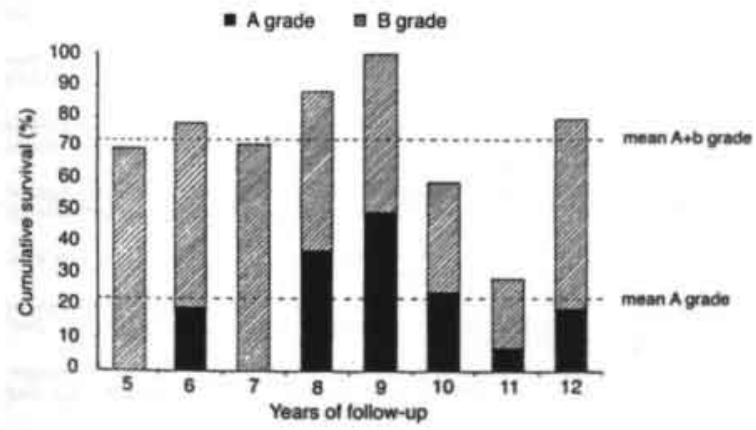

Fig. 2

Changes in the proportions of A and B glohal evaluation grades with length of follow-up showing no tignificant deterioration. 
of Lachmann tests showed side-to-side differences of more than $3 \mathrm{~mm}$, and only $15.5 \%$ showed gross pivot shifts. Among possible explanations are the exclusion from the study of knees with gross instability and the appreciable percentages of isolated $\mathrm{ACL}$ lesions, intrasynovial lesions, and spontaneous reattachments to the PCL. Other factors may be a rehabilitation programme designed to proteci and enhance the healing of the secondary knee restraints, and the population which included many heavy manual workers who do not undertake jumping, cutting and pivoting activities.

The low rate of meniscal injuries and the absence of meniscal surgery later than three years after the index injury are also rather surprising. The same factors and the progressive reduction of activity levels with time may provide an explanation. Only actual surgery on the menisci was recorded, and it is possible that some meniseal lesions in this low-demand population produced only slight symptoms which did not result in recorded meniscal surgery. For obvious ethical and economical reasons, it was impossible to conduct second-look arthroscopic or MRI examinations to provide more rigorous data on secondary meniscal lesions.

Most of the recent papers on ACL lesions deal mainly with athletic or high-demand patient populations, and many focus on the poor results of conservative treatments in this population, with their high incidence of secondary injuries (Noyes et al 1983a; Finsterbush et al 1990), degenerative changes (Fetto and Marshall 1980; Kannus and Jarvinen 1987; Pattee et al 1989), cessation of sport activities (Andersson et al 1989; Sommerlath, Lysholm and Gillquist 1991) and on the need for secondary joint stabilisation (Noyes et al 1983b; Barrack et al 1990). These reports led to the concept that only surgical reconstruction could allow unrestricted return to sport and prevent secondary problems (Daniel and Fithian 1994).

This view remains controversial: a recent study failed to show a higher proportion of contact sports participation at seven years after surgical reconstruction as compared with conservative treatment (Roos et al 1995). It has also been shown that subsequent degenerative changes cannot be avoided, even after the latest surgical techniques which take full account of $\mathrm{ACL}$ anatomy and biomechanics (Sommerlath and Gillquist 1992). Such degenerative changes may be less important in conservatively treated patients (Daniel et al 1994); our limited data support these observations. Various hypotheses have been put forward to explain subsequent degeneration in apparently stable knees.

The extent of concomitant meniscal injury is of course important, but its influence has not been proven (Daniel et al 1994; Küllmer, Letsch and Turowski 1994). Bone 'bruises', sustained at the time of injury, may perhaps damage the subchondral bone (Graf et al 1993; Fowler 1994). Even the geometry of the femoral condyle has been evoked (Friden et al 1993). The mechanical properties of articular cartilage (Setton et al 1994) and changes in synovial fluid cytokines (Cameron et al 1994) have been reported to be influenced by the initial $\mathrm{ACL}$ lesion; these changes may belp to induce degenerative changes in a reconstructed knee which is subjected to further high-demand activities.

Our long-term study indicates that patients who are willing to avoid these activities can have acceptable functional results after non-operative treatment of an ACL injury. The outcome does not appear to deteriorate with time, and includes only very limited osteoarthritic changes. Our findings support previous short-term and medium-term reports on the conservative treatment of ACL injuries (Giove et al 1983; Satku, Kumar and Ngoi 1986; Buss et al 1995). Despite the very numerous publications on the subject, the management of $\mathrm{ACL}$. lesions is almost as controversial today as it has been for 50 years (Lindstrand 1995).

No benefits in any form have been received or will be received from a commercial party related directly or indirectly to the subject of thin article.

\section{REFERENCES}

Anderssen C, Odensten M, Good L. Gillquist J. Surgical or noesurgical treatment of acute rupture of the anterior cruciate ligameni. $J$ Bone Joint Surg [Am] 1989,71-A:965-74.

Barrack RL, Bruckner JD, Kneis! J, Inman WS, Alexander AH. Tne outcome of nonoperatively treated complete tears of the anterior cruciale ligament in sctive young adulis. Clin Orthop 1990:259. 192.9.

Busa DD, Min R, Skyhur M, et al. Nonoperative treatment of acute anterior cruciate ligament injuries in a selected group of patients. Am J Sportx Med 1995:23:160-5.

Cameron ML, Fu FH, Peesaler HH, Schnelder M, Evans CH. Synovial fluid cytokine concentrations as possible prognostic indicators in the ACL-deficient knce. Knee Surg Sports Thasmatol Arthroscopy 1994:2:38-44.

Casteleyn PP, Handelberg F, Opdecam P. Traumatic hacmarthrosis of the Enee, $J$ Bone Joint Sarg $(B r)$ 1988;70-B:404-6

Daniel DM, Fithlan DC. Indications for ACL. surgery. Arthroscops 1994:10:434-41.

Daniel DM, Stene ML, Dobson BE, et al. Fate of the $\mathrm{ACL}$-injured patient: a prospective outcome study. Am J Sports Med 1994:22: 63244.

Fette JV, Marshall JL. The natural history and diagnosis of anterior cruciate ligament insufficiency. Clin Onthop 1980;147:29-38.

Finsterbush A, Frank] U, Matan Y, Mann G. Secondary damage to the knee after isolated injury of the anterior cruciate ligarnent. Am I Sports Med 1990:18:475-9.

Fowler PJ. Bone injuries associated with anterior cruciate ligament disruption. Arthroscopy 1994:10:453-60.

Friden T, Jonsson A, Eriandsson T, Jonsson K, Undatrand A. Eflect of femoral condyle configuration on disability after an anterior cruciate ligament nupture: 100 patients followed for 5 years. Acta Orthep Scand 1993;64:571-4.

Glove TP, Miller SJ IIt, Kent BE, Sanford Tt, Garrick JG. Nonoperative treatment of the tom anterior cruciate ligament. $J$ Bone Joint Siars (Am] 1983;65-A:184-92.

Graf BK, Cook DA, De Smet AA, Keene JS. 'Bone bruises' on magnetic resonance imaging evaluation of anterior cruciate ligament injuries. An $J$ Sports Aled 1993;21:220-3.

Heft F, Maller W, Jakeb RP, Stiubli H.U. Evaluation of Lnce ligament injuries with the IKDC form. Knee Surg Sports Thaumatol Arthroacepy 1993:1:226-34.

Jain AS, Swanson AJG, Murdoch G. Hemarthrosis of the knee joint. Injary 1983:15:178-8i.

Kannus P. Jirvinen M. Conservatively treated tears of the anterior cruciate bigament: long-term results. $J$ Bone Joint Surg (AIt) 1987;69-A:1007-12.

Kallmer K, Letach R, Tarowald B. Which factors influence the progression of degenerative osteoarthritis after $\mathrm{ACL}$. surgery? Knee Sarr Sports Truainatol Arthroscopy 1994:2:80-4. 
Undstrand A. The anterior cruciate ligament problem. Acta Orthop Scand 1995:66:105-6.

MeDaniel WJ Jr, Dameron TB Jn. Untreated ruptures of the anterior cruciate ligament: a follow-up study. I Bone Joint Surg (Am) 1980;62-A.696-705.

Noyes FR, Mooar PA, Matthews DS, Butler DL. The symptomatic anterior cruciate-deficient knee. Part L. The long-term functional disability in athletically active individuals. J Bome Joint Surg [Am] 1983a:65-A:154-62.

Noyes FR, Matthews DS, Mooar PA, Grood ES. The symptomatic anterior cruciate deficient knee. Part II. The results of rehabilitation. activity modification and counselling in functional disability. $J$ Bone Joint Surg [Am] 1983b;65-A:163-74.

Pattee GA, Fox JM, Del Plzzo W, Friedman MU. Four to ten year follow-up of unreconstructed anterior cruciate ligament tears. Am J Sports Med 1989:17:430-5.
Roos H, Ornell M, Gärdsell P, Lohmander LS, Lindstrand A. Soccer after anterior cruciate ligament injury: an incompatible combination? A national survey of incidence and risk factors and a 7.year follow-up of 310 players. Acta Orthop Scand 1995:66:107-12.

Satku K, Kumar JP, Ngol SS. Anterior cruciate ligament injuries: to counsel or operate? J Bone Joint Surg (Br) 1986:68-B.458-61.

Setton LA, Mow VC, Mutler FJ, Pita JC, Howell DS. Mechanical proprieties of canine articular cartilage are significantly aliered follow. ing transection of the anterior cruciate ligament. $J$ Orhop Res $1994: 12: 451-63$.

Sommerlath K, Lyshoim J, Gillquist J. The long-term coune after treatment of acute anterior cruciate ligament ruptures: a 9 to 16 year follow-up. Am J Sports Med 1991;19:156-62.

Sommerlath K, Gillquist J. The long term course of various meniscal treatments in anterior cruciate ligament deficient knees. Clin Orthop $1992 ; 283: 207-14$ 


\title{
MANAGEMENT OF ANTERIOR CRUCIATE LIGAMENT LESIONS : SURGICAL FASHION, PERSONAL WHIM OR SCIENTIFIC EVIDENCE? STUDY OF MEDIUM- AND LONG-TERM RESULTS
}

\author{
P. P. CASTELEYN
}

The medium- and long-term results of conservative and surgical treatment of $\mathrm{ACL}$ lesions were evaluated by analysis of the current literature. Ondy reports with a minimum follow-up of 4 years were taken into account. Concerning conservative treatment, the literature search revealed onily 7 papers with a total of 636 cases. Reports on the results of surgical treatment were separated into four eategories : primary repairs, with 13 papers 11205 cases), extraarticular tenodesis, with \& papers (232 cases), ACL reconstruction, with 26 papers (2693 cases) and $\mathrm{ACL}$ prosthetic replacement (reconstruction using syntheties) with 5 papers ( 370 cases).

The mean functional scores show about $70 \%$ good and excellent results for all treatment regimens. Clinical laxity persists in almost all conservatively treated cases. in almost half of the cases with primary repair. extraarticular tenodesis, and synthetic substitution. and in aimost one-third of the cases with $\mathrm{ACL}$ reconstruction.

The incidence of secondary ACL. surgery $(4.6 \%)$ was lowest in the conservative group, whereas secondary meniscus surgery was lowest in the $\mathrm{ACL}$ reconstruction group $(3.5 \%)$. Compared with the conservative group (12\%), surgical treatment evolved to a higher ostcoarthritic morbidity. Sports participation was higher in the ACL reconstruction group. This analysis may provide a more realistic view on the outcome of treatment of $\mathrm{ACL}$ lesions, and on the relationship berween rrearment. activiry level and osteoarthritis.

Keywords : knee : anterior cruciate ligament : medium $\&$ long term results.

Mots-elés : genou : ligament croisé antérieur : résultats a moyen et long terme.

\section{INTRODUCTION}

Social behavior, recreational and sports activities, as well as occupational and traffic accidents seem to be generating an epidemic of knee and especially $A C L$ injuries.

This led some authors $(11,30)$ to project figures of more than $250.000 \mathrm{ACL}$ injuries, year worldwide. It is estimated that between 60.000 and 75 . 000 surgical $\mathrm{ACL}$ reconstructions; year are presently performed per year in the U.S.A. $(30,39)$. This trend towards operative treatment was further enhanced by reports of progressive joint degeneration due to chronic ligamentous pathoiogy ( 14 . 29). Recent review articles and editorials challenged this view however and reimphasized the value of conservative treatment $(32,38,39,46)$.

Although the orthopedic literature is replete with the management of $\mathrm{ACL}$ problems, most reports on treatment concern details of surgical technique, and/or short-term results. The fundamental questions concerning the treatment of the ACL lesions thus remain unsolved.

The aim of this study was therefore to search the literature to provide an analysis of the available

Department of Orthopedics and Traumatology, Vnje Uni versiteit Brussel, Brussels. Belgium.

Correspondence and repriats: P. P. Casteleyn. Depe. of Orthopedics and Traumatology, Academic Hospital of the Vnje Universiteit Brussel. Laarbeeklaan 101. B-1090 Brussets Beigum. 
medium- and long-term reports of conservative and surgical treatments of $\mathrm{ACL}$ lesions.

\section{MATERIAL AND METHODS}

The main orthopedic joumals and monographs were researched from 1975 until mid-1998 for reports on medium- and long-term results of $\mathrm{ACL}$ treatments.

It was the initial intention of the author to use a strict methodology for paper selection, focusing on objectively measurable variables, separate evaluation of different pathologies (chronic versus acute, partial versus total ACL tears, isolated versus combined lesions), population groups (low versus high demand, young versus middle-aged), and randomized treatment modalities.

These scientific standards had to be abandoned however, as almost none of the available papers fullililed the above-mentioned criteria. The only selection criterion that could possibly be maintained was a minimum follow-up of 4 years.

Reports with a mean follow-up of 4 years or more. but including cases with less than a tyear follow-up were not taken into account owing to possible biases related to favorable short-term results.

The following data were analyzed if avalabie number of cases reported, percentage of eases followed , length of follow-up (mean and range), type of $\mathrm{ACL}$. lesion (partial versus total, acute versus chronic), treatment regimen. residual laxity (Lachmann test. instrumented Lachmann test. pivot shift test). type and value of functional score, sports participation, secondary meniscal and $\mathrm{ACL}$ surgery, loss of motion and osteoarthritis.

The reports on conservative treatment. on primary surgical repair. on extraarticular tenodesis, on $\mathrm{ACL}$ reconstruction and on $\mathrm{ACL}$ prosthetic replacement. were evaluated separately.

Treatment results of acute and chronic ACL lesions. as well as of different surgical reconstructive techniques could not be analyzed separately, owing to the limited number of reports available. A staristical evaluation and comparison between the different treatment groups could not be performed because of the lack of precise data in most reports.

\section{RESULTS}

\section{A. Conservative treatment}

Only seven reports $(6,13,15,20,62,69,72)$ concerning 636 cases reach the benchmark of 4 years of follow-up. Five of the 7 reports include patients with more than 10 years of follow-up. The main follow-up rate is $78.5 \%$ (range $57-96 \%$ ) (table I).

Although the functional results are satisfactory with a mean of $70 \%$ good and exceilent results (range $57-82 \%$ ), the clinical evaluation demonstrated the persistence of knee laxity, with $89 \%$ positive Lachmann's (range 9 to $100 \%$ ), $58.5 \%$ positive instrumented Lachmann's (range 9 to $84 \%$ ) and $59 \%$ positive pivot shifts (range 5 to $84 \%)$.

Sports participation is rather low (mean $45 \%$. range 30 to $55 \%$ ). The amount of high-level sports participation never exceeds $30 \%$, even in series reporting specifically on "athletes". A constant trend is the decline in sports participation over time after the index injury. However in most series which mention this phenomenon, this decline is not related to the knee injury in one-third to onehalf of the cases. This non-knee related decline in sports participation also increases with length of follow-up.

Secondary ACL reconstructions are rare (mean 4.6\% range 0 to $18 \%$ ) and are in most series related to gross or recurrent instability during activities of daily living.

Secondary meniscal surgery is also limited (mean $12 \%$, range $3.5-23.7 \%$ ).

The mean occurrence of osteoarthritis is moderate $(18 \%)$, but with a wide range of values 17 to $61 \%$ ).

\section{B. Primary repair}

The reports on primary repair include sutures as well as reinsertions of the torn ACL remnants, or repairs augmented with autogenous tissue, be it fascia lata, patellar or hamstring tendons $(6,7$. $10,16,26,28,35,36,41,47,68,71,75$ ) (table II).

It is striking that only 13 papers report on a follow-up of more than 4 years, with only 4 papers including patients with more than 10 years of follow-up. All reports together amount to only 1205 cases of ACL ruptures of which 1 out of 5 was lost to follow-up.

Nithough many scores are in the good and excellent range, residual laxity is not rare, with 
21 to $94 \%$ (mean $41.9 \%$ ) positive manual Lachmann tests. The instrumented Lachmann's show even less good values of about 31 to $73 \%$ (mean $52.5 \%$ ) positive tests. The results of the pivot shift tests are less reliable, since the values differ widely between series, with a range from 6 tot $55 \%$ (mean $23.7 \%$ ).

About $45.2 \%$ of this primary repair patient population returned to sports participation after the $\mathrm{ACL}$ injury and repair. The information on secondary meniscal and $\mathrm{ACL}$ surgery remains fragmentary, with widely scattered values. The incidence of secondary meniscal surgery ranges from 2 to $38 \%$ (mean $16.4 \%$ ); that of secondary ACL surgery from 0 to $25 \%$ (mean $12.0 \%$ ).

\section{Extraarticular tenodesis}

The reports available concern isolated extraarticular tenodeses, without intraarticular $\mathrm{ACL}$ reconstruction, for chronic ACL deficiencies (5, 17. 34,65 ) (table III). Although extraarticular tenodeses have apparently been used widely, the number of long-term reports is limited, with only four papers, dealing with 232 patients of whiom only $60 \%$ have been followed.

The scores do not seem too bad and range from 52 to $32 \%$ good and excellent resuits. The validity of the scores is however directly challenged by the high number of positive Lachmann (mean $54.3 \%$. range $37 \%-91 \%$ ), instrumented Lachmann (mean $63.0 \%$, range $63 \%-64 \%$, ) and pivot shift tests (mean $47.4 \%$, range $33 \%-75 \%$ ). Sports participation after the procedure is reduced to a mean of $54.2 \%$.

Secondary meniscal and ACL surgery (respectively 5 to $28 \%$, mean $23.4 \%$ and 6 to $26 \%$, mean $13.6 \%$ ) as well as arthritic degeneration (13 to $51 \%$ ) is frequent.

\section{D. $\mathrm{ACL}$ reconstruction}

Again, the number of reports and cases with a follow-up of more than 4 years is fairly low : only 26 papers or 2693 patients, of whom $23 \%$ were lost to follow-up $(1,3,4,8,9,20,22,36$. $37,40,44,45,50,52,53,54,57,61,63,64,66$.
$67,73,74,78,79), 7$ papers include cases with 10 year or more of follow-up (table IV).

Only three of these papers $(3,36,57)$ deal exclusively with acute $A C L$ lesions; two others report separately on acute and chronic $\mathrm{ACL}$ lesions $(20,50)$, and seven reports combine the results of acute and chronic cases $(8,9,37,40$, $45,61,63)$. All other studies are limited to chronic $\mathrm{ACL}$ lesions.

Many studies also combine the results of different types of grafts, of operative techniques, of various types of isolated intraarticular reconstructions or of intraarticular reconstructions combined with extraarticular tenodeses. The evaluation of each technique is therefore almost impossible. In addition the majority of these studies are retrospective, and when combining techniques, without randomization.

Again, as with the primary repairs, we can witness a discrepancy between rather good functional scores (Lyshoim 66\% to $100 \%$ good and excellent, Cincinatti $66 \%$ to $85 \%$ good and excellent, IKDC $47 \%$ to $77 \%$ A and B) and rather fair and poor results concerning laxity (positive Lachmann: 4 to $91 \%$, mean $34.8 \%$, positive instrumented Lachmann : 6 to $70 \%$, mean $31.1 \%$. positive pivot shift : 3 to $52 \%$, mean $20.8 \%$ ).

The data concerning secondary meniscal and ACL surgery are fragmentary and fall within a wide range of values from 0 to $15 \%$ (mean $3.5 \%$ ) for meniscal surgery and from 0 to $14 \%$ (mean $8.0 \%$ ) for $\mathrm{ACL}$ surgery.

Only 14 papers, reporting on 865 cases (or $31 \%$ of all analyzed cases), studied the appearance or aggravation of osteoarthritis with radiographs and/or bone scans. These papers show $37.4 \%$ of cases (range 12-100\%) to have developed osteoarthritis, mostly of a mild-to-moderate grade.

\section{E. Ligament prostheses}

The synthetics were studied separately, as in cluding them in the global evaluation of the $\mathrm{ACL}$ reconstructions could be considered to create a negative bias in the evaluation of the latter.

Only five long-term reports on ACL prostheses are available with two including patients with 


\begin{tabular}{|c|c|c|c|}
\hline 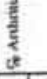 & & $1 \bumpeq \overline{0}-$ & $11=\tilde{a}$ \\
\hline & 2 & $z \equiv 00$ & $2 \approx-\pi$ \\
\hline : & $\lesssim$ & $\approx n \approx \Xi$ & $-x 2=$ \\
\hline 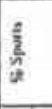 & 2 & $\frac{x^{2}}{2}=$ & $\approx 7 \approx$ \\
\hline$\frac{x}{3}$ & & 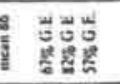 & 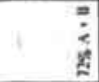 \\
\hline 2 & & 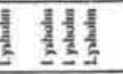 & $1: \frac{\ddot{z}}{\underline{z}}$ \\
\hline$\frac{\dot{z}}{3}$ & $=$ & $=7 n \pi$ & -53 \\
\hline$\frac{1}{2}$ & है & 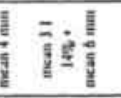 & 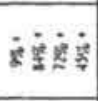 \\
\hline 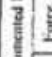 & $\stackrel{2}{2}$ & ह & 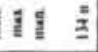 \\
\hline$\frac{3}{2}$ & 吾 & $\frac{3}{5} \frac{3}{2}$ & $\frac{8}{x}=\frac{\beta}{x}$ \\
\hline$\frac{1}{4}$ & $\Rightarrow$ & $=325$ & \\
\hline$\underline{2}$ & & $\frac{5}{3}$ & 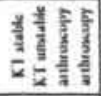 \\
\hline 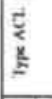 & & $\frac{3}{\frac{3}{2}} \frac{\vec{z}}{\frac{1}{2}}$ & 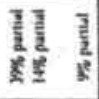 \\
\hline$=$ & & $\approx \approx \approx$ & $2:=$ \\
\hline : & & - $\tilde{e}==$ & $: \equiv=$ \\
\hline & 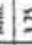 & $E \cdots \infty$ & $=2-$ \\
\hline $\begin{array}{l}3 \\
2 \\
2\end{array}$ & & 2 $\quad 21=$ & $\Rightarrow a=$ \\
\hline$\frac{8}{2}$ & & $\Rightarrow \quad 3=\pi$ & $x \bar{a} 3 \overline{3}$ \\
\hline У & 2 & $=22 \pi$ & $z \approx x$ \\
\hline 产 & 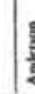 & 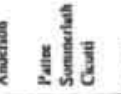 & 竞竞竞 \\
\hline
\end{tabular}

\begin{tabular}{|c|c|}
\hline$\frac{1}{2}$ & 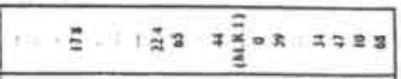 \\
\hline$\frac{3}{3} \frac{3}{2}$ & 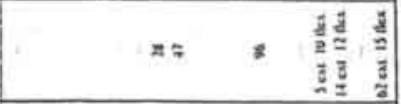 \\
\hline \begin{tabular}{|l|l|}
3 \\
3 \\
\hdashline
\end{tabular} & $\approx \equiv 0 \geq \approx+\stackrel{n}{=} \Rightarrow$ \\
\hline$\frac{7}{2}$ & 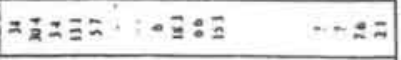 \\
\hline 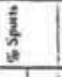 & 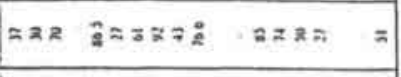 \\
\hline \begin{tabular}{l|l}
$n$ \\
3
\end{tabular} & 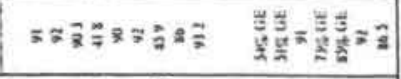 \\
\hline 2 & 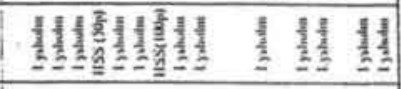 \\
\hline$\frac{1}{2}$ & $=\dot{\equiv}=2 x+2 \quad \cdots \approx 2 \approx 2$ \\
\hline 11 & 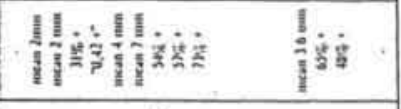 \\
\hline i⿱ & $\begin{array}{ll}z z & i z \\
z & i\end{array}$ \\
\hline$\frac{1}{2}$ & 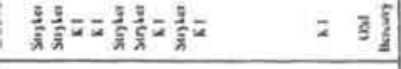 \\
\hline$\frac{1}{4}$ & $73 x=2527$ \\
\hline 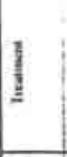 & 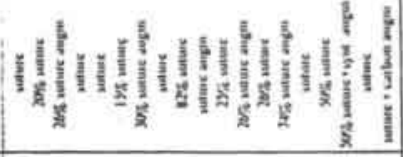 \\
\hline$\frac{1}{2} z$ & $\underline{B}=\quad=2: 2 \pi$ \\
\hline $2 \frac{3}{2}$ & $1 \quad 0 \quad n=0, \quad 20$ \\
\hline$\frac{1}{2}$ & 1. $0=:-2 n+1=n$ \\
\hline$=\frac{1}{2}$ & nomotomn an mo \\
\hline$\frac{2}{2}$ & $22=25=03 R$ F $3 \approx$ is \\
\hline $\int_{z}^{n}$ & 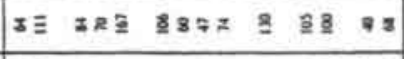 \\
\hline 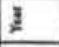 & 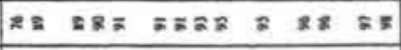 \\
\hline 3 & 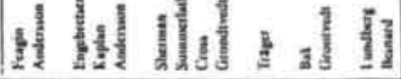 \\
\hline
\end{tabular}

\begin{tabular}{|c|c|}
\hline$\frac{1}{2}$ & 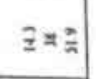 \\
\hline$\frac{3}{3}=1$ & 9 \\
\hline 章| & 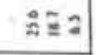 \\
\hline \begin{tabular}{l|l}
7 \\
$\frac{1}{3}$ \\
$\frac{3}{2}$
\end{tabular} & $\bar{x} \bar{x} \equiv$ \\
\hline 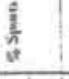 & $-\hat{z} \neq$ \\
\hline हैं & 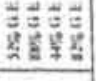 \\
\hline$\frac{1}{2}$ & 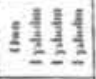 \\
\hline 竞 & $\bar{n}=$ \\
\hline is & $x=$ \\
\hline$\frac{1}{2}$ & $\begin{array}{ll}2 & 1 \\
1 & 1\end{array}$ \\
\hline $1 \frac{1}{2}$ & $=z$ \\
\hline & 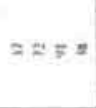 \\
\hline$\frac{4}{12}$ & $\frac{\frac{1}{1}}{\frac{1}{2}}=\frac{1}{\frac{1}{2}} \frac{1}{1}$ \\
\hline$=\frac{3}{2}$ & $=0=$ \\
\hline$\frac{\pi}{2}$ & $z=z=$ \\
\hline$\frac{5}{2}$ & man \\
\hline$\frac{3}{2}$ & $a=z=7$ \\
\hline $\begin{array}{l}8 \\
2 \\
\end{array}$ & $9=93$ \\
\hline 3 & $z= \pm \approx$ \\
\hline$\frac{3}{3}$ & $1 \frac{1}{2}$ \\
\hline
\end{tabular}


1"

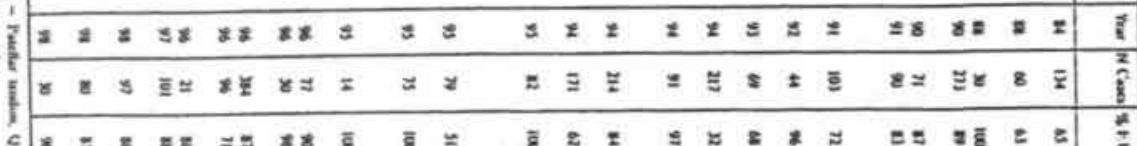

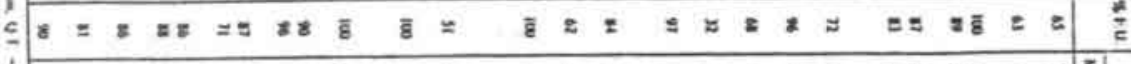

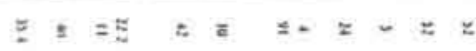

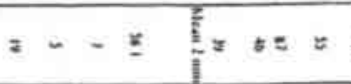

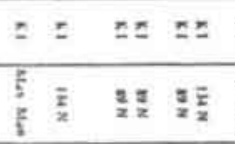

?

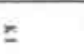

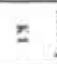

$z-\underline{x}$

$\frac{F}{3} \quad \frac{7}{2}=$

$=$ $f\left(\frac{1}{x}\right.$

$z x=x=-+z-\bar{z} z z z$

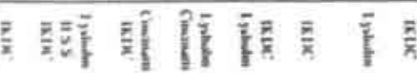

$\frac{l}{2}$

$\frac{7}{2}$

$\stackrel{2}{2}$ $-\mid \frac{\frac{3}{2}}{2}$

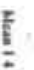

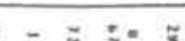

$\bar{E}=1=\Sigma e \bar{c}$

- E $=\underline{E}$

$z$

$\stackrel{2}{2}$

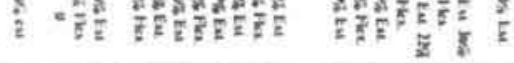

$-z=z$

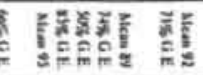

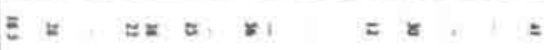

\begin{tabular}{|c|c|c|c|c|c|}
\hline$\frac{F}{1}$ & 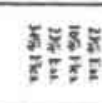 & ? & & 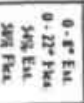 & $\frac{7}{8}$ \\
\hline$=$ & $z=v$ & $1=$ & 12 & $1=$ & $=\sum_{\frac{1}{5}}$ \\
\hline
\end{tabular}


more than 10 year follow-up $(19,23,48,49,51)$ (table V).

The total number of cases (370) is very low, but with a follow-up of $77 \%$. Two of the reported series were treated with the Leeds-Keio synthetic ligament scaffold, but the arthroscopic, operative and histological follow-up data show that it does not induce a valid neoligament and therefore acts as a prosthesis. The synthetic reconstructions were overwhelmingly performed in chronic cases. Fiftyeight percent of the patients (range 17 to $85 \%$ ) demonstrated a positive Lachmann, $38.6 \%$ (range $31 \%-50 \%)$, a positive instrumented Lachmann and $41.7 \%$ (range 25 to $62 \%$ ) a positive pivot shift.

In contrast with the other treatment regimens we seem to find a better correlation between the laxity values and the functional score, with a low $71.3 \%$ of Lysholm good and excellent scores (43 to $78 \%$ ). The mean sports participation was $54.6 \%$ (range 52 to $83 \%$ ).

The protective effect of the synthetic ACL reconstruction against further meniscal lesions is questionable, given the $23.2 \%$ incidence (range 14 to $40 \%$ ) of postreconstruction meniscal surgery.

Synthetic ACL grafts seem doomed to failure through fatigue and abrasion, and this is reflected by a $17.6 \%$ incidence (range 7 to $51 \%$ ) of further ACL surgery. The fragmentary data in the reports concerning postoperative loss of motion seem to indicate a lower rate of iatrogenic loss of motion. but the degree of secondary osteoarthritic degeneration towers above the resuits of all other procedures ( $50 \%$ to $83 \%$ ).

\section{F. Comparison of the different procedures}

The analysis of the long-term results of primary repair, extraarticular tenodesis, reconstruction and prosthetic replacement of the $\mathrm{ACL}$ confirm that the best results bave been obtained with $\mathrm{ACL}$ reconstructions (table VT).

$A C L$ reconstructions were also compared with conservative treatments (table VII). The mean follow-up of the conservatively treated series is somewhat longer, with also substantially more reports $(71 \%$ versus $27 \%)$ including patients with at least 10 years of follow-up. The most striking difference between both treatment regimens concerns the residual knee laxity.

After conservative treatment almost all patients $(89 \%)$ still demonstrate a positive Lachmann and 2 out of $3(59 \%)$, a positive pivot shift.

The surgical treatment can abolish the Lachmann and instrumented Lachmann in about 2 out of 3 cases (respectively 34.8 and $31.1 \%$ ) and the pivot shift in about 4 out of 5 cases $(20.8 \%)$.

The mean functional scores seem to yield neariy identical results with surgical $(73 \%$ good and excellent results) and conservative ( $70 \%$ good and excellent results) treatments.

There is a marked difference in the incidence of secondary ACL surgery after conservative $(4.6 \%)$ and surgical $(8.0 \%)$ treatment, the latter surprisingly being twice as frequent. The lower rates of secondary meniscal surgery after $\mathrm{ACL}$ reconstruction $(3.5 \%$ versus $12 \%$ after conservative treatment) show the protective role of the surgical reconstruction.

The broad range of secondary meniscal surgery after conservative treatment $(3.5-23.7 \%$ ) indicates however that persistant $\mathrm{ACL}$ deficiency is not the only factor in the genesis of further meniscal injury. The reported percentages of secondary osteoarthritis are somewhat higher after surgical treatment (37. $4 \%$ versus $27.6 \%$ after conservative treatment).

\section{DISCLSSION}

Reviewing the above-mentioned medium-term reports and results, one is astonished by the paucity of the available data concerning a rather frequent pathology, for which surgical techniques have often been advocated.

The scientific value of this analysis can be questioned, owing to the poor scientific standard of almost all published reports.

Arbitrary selection of patients, short follow-ups with low follow-up rates, and nonrandomised treatment regimens are the main culprits inducing unacceptable biases and limiting the usefulness of most reports. 


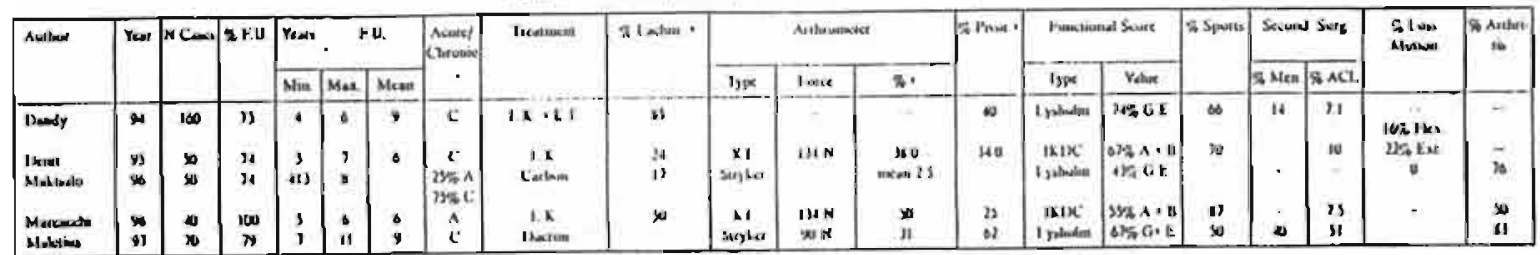

No:

IX Lod . Kow

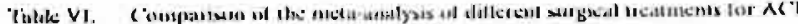

\begin{tabular}{|c|c|c|c|c|c|c|c|c|c|c|}
\hline \multirow[t]{2}{*}{ 'I'iculutenI } & \multicolumn{2}{|c|}{$\mathrm{N}=$ reports } & \multirow[t]{2}{*}{ lintal $N^{6}(a)$} & \multirow[t]{2}{*}{ \%11. } & \multirow{2}{*}{ 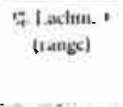 } & \multirow{2}{*}{$\begin{array}{l}\text { S. Aus. I isclus ' } \\
\text { (range) }\end{array}$} & \multirow{2}{*}{$\begin{array}{l}\text { Sul'irus " } \\
\text { (tange) }\end{array}$} & \multicolumn{2}{|c|}{ Sccond. Sirg } & \multirow[t]{2}{*}{ So Spusis } \\
\hline & ン y I:U & $\begin{array}{l}\text { sorne caxes } \\
>111 \text { y } 111\end{array}$ & & & & & & F Men & שACI. & \\
\hline P'rimasy rсраar & I) & t & 1.2us & su & $\begin{array}{c}413 \\
(3) \cdot 24)\end{array}$ & $\begin{array}{c}5: 5 \\
(11-11)\end{array}$ & $\begin{array}{c}31) \\
(0.55)\end{array}$ & $\begin{array}{c}101 \\
(0-38)\end{array}$ & $\begin{array}{c}12.0 \\
(0-25)\end{array}$ & $\begin{array}{c}41 ? \\
(2) \cdot 42)\end{array}$ \\
\hline $\begin{array}{l}\text { lixtraarticutar } \\
\text { tetodestr }\end{array}$ & 4 & J & $31 !$ & (t) & $\begin{array}{c}343 \\
\text { (J) }-91 \text { ) }\end{array}$ & $\begin{array}{c}030 \\
(b 1-4)\end{array}$ & (3). 13 ) & $\begin{array}{c}23-1 \\
(j-2 x)\end{array}$ & $\begin{array}{c}11.6 \\
(5 \cdot 26)\end{array}$ & $\begin{array}{c}35.7 \\
(H \cdot 74)\end{array}$ \\
\hline Reconstruction & 26 & ， & $\left.2\left(1^{1}\right)\right\}$ & $n$ & $\begin{array}{l}3.8 \\
(4-9)\end{array}$ & $\begin{array}{c}1]\} \\
\{18-71)\}\end{array}$ & $\begin{array}{c}20.8 \\
(3-52)\end{array}$ & $\begin{array}{c}13 \\
(0.15)\end{array}$ & $\begin{array}{c}10 \\
(0 \cdot 14)\end{array}$ & $\begin{array}{c}\text { Hd } \\
|8 \cdot|(x) \mid\end{array}$ \\
\hline Syntistio & $s$ & $?$ & 570 & $n$ & $\begin{array}{c}580 \\
(17-85)\end{array}$ & $\begin{array}{c}386 \\
(3) \cdot 50)\end{array}$ & $\begin{array}{c}+1.7 \\
(25-62)\end{array}$ & $\begin{array}{c}212 \\
(14-40)\end{array}$ & $\begin{array}{c}176 \\
17-31)\end{array}$ & $\begin{array}{c}540 \\
(52.83)\end{array}$ \\
\hline
\end{tabular}

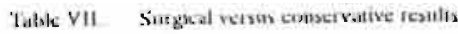

\begin{tabular}{|c|c|c|}
\hline & I misctrative thestment & Surgical tisarment \\
\hline \% I achmann & $80(9-100)$ & $348(4-91)$ \\
\hline 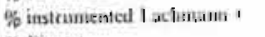 & $58.5(9-84)$ & $31(16-21)$ \\
\hline Otheje & 3) $(5-5+3)$ & $208(3-52)$ \\
\hline S geod/ exc fonce woic & $20(3) \cdot 82)$ & $33(47-100)$ \\
\hline Forts pustocipation & $+5(30.55)$ & $24+(8-1100)$ \\
\hline$\%$ scusndary $A C 1$ surgery & $40(10-|x|$ & $80(0-14)$ \\
\hline 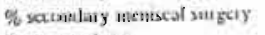 & $120115-217$ & $15(0-151$ \\
\hline \%ostevartheritis & $18(7-01)$ & $37+(12-100)$ \\
\hline
\end{tabular}


This is therefore not an ideal meta-analysis which can provide indisputable results and conclusions.

It is however the only available pooled evaluation of medium- and long-term results of $\mathrm{ACL}$ treatments, and it could have informative value concerning ACL management.

Many of the reports on primary repair concern a fair number of isolated and partial ACL lesions, which can generate a favorable bias.

Isolated extraarticular tenodeses show an unacceptable recurrence rate of knee laxity over time and most authors agree that these techniques should no longer be used. Short-term reports on the association of extraarticular tenodeses with intraarticular ACL reconstructions yield conflicting results $(56,59,77)$.

The results of surgical reconstructions can be biased by the pooling of results of chronic and acute cases, as the results of treatment of chronic ACL deficiency are less optimal (58).

II is difficun to group and compare studies concerning intraarticular reconstructions of the $\mathrm{ACL}$, owing to the wide spectrum of different techniques used.

The reconstruction can be performed open or arthroscopically, through tibial and femoral bone tunnels, or with the graft routed "over the top" of the lateral femoral condyle.

The graft materials, for which the relative strength and stiffness were extensively studied, are mostly fascia lata, patellar tendon and/or quadriceps tendon, and bamstring tendons.

Autografts as well as allografts, also of the Achilles tendon, have been used $(57,58)$.

The latter have been processed deep-frozen, freezedried, sterilized with ethylene oxide, or with gamma radiation. These processings also influence the mechanical characteristics of the grafts (80).

Xenografts on the other hand have been relatively rapidly discarded, bacause of deleterious short-term results.

The fixation of the graft is performed with sutures, bone screws, interference screws, staples or special anchors. Surgical techniques also evolve over time, sometimes on unproven grounds (32), but aiso based upon better knowledge of graft materiais and intraarticular anatomy.

It has been suggested, but not demonstrated, that the iatrogenic complications, as well as some poor outcome results after $\mathrm{ACL}$ reconstruction. are related to imperfect surgical techniques and inadequate or suboptimal anatomic reconstructions $(4,27)$.

One can question this view, considering the tremendous emphasis on surgical techniques for $\mathrm{ACL}$ reconstruction to be found in the literature and the huge number of $\mathrm{ACL}$ reconstructions performed (30).

Moreover, the laxity after surgical treatment remains worrisome, as it is seen to progress over time $(18,36,64,66,79)$, and since a notable proportion of patients will uitimately not be stabilized by the procedure.

A few reports $(36,37,61,64,66,79)$ studied the laxity and the functional scores at different time intervals. Johnson found no difference in laxity scores after 5 to 7.5 years of follow-up. compared with 7.5 to 10 years of follow-up (37).

A recent paper did not report an increasing laxity between 1 and 5 years of follow-up (61).

Most other sequential reports show a detenoration to occur, mostly between 2 and 5 years of follow-up. This probably explains Johnson's absence of difference, as the laxity had already recurred before the 5- to 7.5-year time interval. The deterioration is mainly visible in the laxity data, less in the functional scores. The latter can paradoxically improve, but this is mostly the effect of regaining some motion which had been reduced due to the reconstructive procedure.

Due. to many pessimistic short- and mediumterm reports, the use of synthetics has nowadays been virtually discontinued $(33,43,55,60)$. De Smedt (24) has clearly demonstrated that the broad dissemination of these unproven techniques and devices fooled numerous surgeons, and led thousands of patients to be submitted to operative treatments of which the results could bave been predicted by a few scientifically sound reports.

The high number of prosthetic ligament failures, combined with foreign body reactions to abrasion 
particles even generated the development of specific revision techniques (32).

The association of mechanical degradation through laxity and meniscal loss, with biological degradation through particle-induced foreign body synovitis, probably explains the high rate of secondary osteoarthritis after procedures using synthetics.

The present analysis aiso shows a discrepancy between functional scores and clinical laxity tests. Laxity values obtained by static laxity tests are of course useful evaluation data, but their value and relevance have to be considered with caution.

Indeed, the forces applied to the articular structures of the knee during these tests are probably very small compared to the forces generated during activities of daily living and sports. The acceleration and the resultant tissue strain could also be extremely different.

This hypothesis explains the higher percentages of positive instrumented Lachmann's found when testing the same knees with increasing displacement forces, e.g. as with the KT 1000 at 89 and 134 Newton and at maximal manual displacement force $(3,20)$,

On the other hand, Vergis and Gillquist have shown that $\mathrm{ACL}$ deficient knees, when tested with an electrogoniometric system during single step ascents and descents, were able to keep the active dynamic laxity within normal limits. despite revealing abnormal laxity during static tests (76). This emphasizes the role of proprioception and knee muscle activity.

As all functional scores are based partially on the patient's subjective assessment and symptoms, it is clear that the latter, and therefore also the scores, are closely activity-related.

A cascade of events has been described going from $\mathrm{ACL}$ disruption (associated or not with meniscal injuries) over to secondary reinjuries with meniscal tears and to joint arthritis (21).

The effect of $\mathrm{ACL}$ reconstructive surgery on this cascade of events remains unclear, and the further evolution of osteoarthritis is clearly not exclusively meniscus-related.
Whereas the surgical reconstructions suffer fewer secondary meniseal lesions, they end up with a higher percentage of osteoarthritis. Sommerlath had already demonstrated that there was a significant variation in osteoarthritis in $\mathrm{ACL}$-deficient knees, not only related to the degree of meniscal loss, but also to the activity level $(70)$. These clinical impressions were confirmed by Daniel et al., who reported an increased incidence of osteoarthritis, diagnosed by radiology and bone scanning, in patients with "successfully" reconstructed knees. This could not be explained by a significantly higher incidence of nieniscal surgery in patients who had undergone $\mathrm{ACL}^{-}$reconstructions (20).

Similar findings were also reported by Fritschy et al. (31) and Aglietti et al. (2). The common link between these reports is a higher activity level in the $\mathrm{ACL}$ reconstructed knees, perhaps allowed by the $\mathrm{ACL}$ reconstruction?

The ratio of Noyes and Barber (56), 1:3 worse. 1/3 unchanged, 1/3 improved, is often quoted as what to expect from nonoperative treatment protocols. However the present analysis of nonoperative treatments of acute ACL injuries demonstrates clearly better results.

Series reporting the resuits of conservative treatment in lower activity level populations, and others in which treatment included patient counseling to avoid cutting, pivoting and jumping sports also report markedly lower rates of secondary meniscal surgery $(13,62)$ compared with series of conservative treatment in higher activity level populations with unrestricted sports participation $(6,15,20)$. The rather low activity level. resulting in a reduced incidence of secondary meniscal lesions, can also explain the low rate of osteoarthritis. The only conclusion that can be drawn from the comparison of scores of surgical and conservative treatment, is that both treatment regimens offer almost equal results, but probably at different activity levels, as illustrated by the difference in sports participation which is aimost twice as frequent after surgical treatment $(74 \%)$ as after conservative treatment $(45 \%)$.

Sports participation bas to be questioned as an outcome criterion of $\mathrm{ACL}$ treatment. Whereas 
sports participation at the same level, with the same frequency and intensity, was considered in former years "the" success criterion of $\mathrm{ACL}$ treatment, more thorough data on the imperfect nature of available ACL treatments have now shed a different light on ACL treatment outcome (27. 32).

The real benchmarks of success have to be the avoidance of treatment morbidity, secondary surgery and osteoarthritis. This supports the hypothesis of Dye of the "envelope of function" as a zone in which articular homeostasis can be maintained in relation to some intensity and frequency of articular loading (25). This "envelope of function" can probably not be totally restored by $A C L$ reconstruction, and unrestricted loading disrupts the homeostasis, which leads to osteoarthritis. On the other hand a more limited activity level with an unreconstructed knee can still allow articular homeostasis.

Nonetheless the orthopedic community has until now failed to produce sufficient well documented. randomised, long-term reports in order to establish a scientific evidence basis for the managtment of ACL lesions.

Even taking into account the difficulties reiated to, and the energy required by. these studies. surgeons frequently confronted with $\mathrm{ACL}$ pathology should consider participation in these studies as an ethical duty, notwithstanding patient demands and economic pressures.

\section{REFERENCES}

1. Agtietti P. Buzai R., D'Andria S., Zaceherotti G. Long term study of anterior cruciate ligament reconstruction for chronic instability using the central one-third patellar tendon and a lateral extraarticular tenodesis. Am. J. Sports Med., 1992, 20, 38-45.

2. Aglietti P., Burzi R., Zaccberotti G., De Biase P. Patellar tendon versus doubled semitendinosus and gracilis tendons for anterior cruciate ligament reconstruction. Am. J. Sports Med., 1994, 22, 211-218.

3. Aglietti P., Buszi R., Menchetti P. P., Giron F. Arthroscopically assisted semiteadinosus and gracilis tendon graft in reconstruction for acute anterior cruciate ligament injuries in athietes tol. J. Sports Med.. 1996, 24, 726731.
4. Aglietti P., Bumi R., Giron F., Simeone A. J., Zaccheroti G. Arthrascopic-assisted anterior cruciate ligament reconstruction with the certral third patellar tendon: A 5-8 year follow-up. Knee Surg. Sports Traumatol. Atthroscopy, 1997, 5, 138-144.

5. Amirault J. D. Cameron J. C., Maclntosh D. L., Marks P. Chronic anterior cruciate ligament deficiency ; Long term results of Maclntosh's lateral substitution reconstruction. J. Bone Joint Surg., 1988, 70-B, 622-624.

6. Andersson C. Odensten M.. Good L., Gillquist J. Surgical or non-surgical treatment of acute nupture of the anterior cruciate ligament : A randomized study with long term follow-up. J. Bone Joint Surg., 1989, 71.-A. 965-974.

7. Andersson C., Odensten $\mathrm{M}$., Gillquist J. Knee function after surgeal or non-surgeal treatment of acute rupture of the anterior cruciate ligament : a randomized study with a long term follow-up period. Clin. Orthop. 1991. 264, 255-263.

8. Anderson A. F. Snyder R. B.. Lipscomb A. B. Antenor cruciate ligament reconstruction using the semutendinosus and graclis tendons augmented by the Losee ulotibial band tenodesis : A long term study. Am. J. Sports Med. 1994, 22, 620-626.

9. Bach. B. R. Tradonsky S. Bojchuk J. at al. Arthroscopically assisted anterior cruciate ligamient reconstruction using patellar tendon autograft. Five-to-nine-year followup evaluation. Am. J. Sports Med., 1998, 26, 20-29

10. Besnard P. Goutallier D. Suture du ligament croise anterieur renforcte par des fibres de carbone. Résultats anatomiques et dégradation articulaire is 8 ans de recul. Rev, Chir, Orthop. 1998, 34, 162-171.

II. Bobic V, Current concepts in anterior cruciate ligament reconstruction. Surgery, 1992, 10, 241-247.

12. Buekley S, L. Barrack R. L. Herbert-Alexander A. The natural history of conservatively treated partial antenor eruciate ligament tears. Am. J. Sports Med. 1989. 17. $221-225$.

13. Casteleyn P. P., Handelberg F. Nonoperative management of anterior cruciate ligament injuries in the general population. J. Bone Joint Surg. . 1996, 78-B, 446-451.

14. Charnbat P. Le ligament croisé antétieur. In: Duparc J. ed. Cahiers d'enseignement S.O.F.C.O.T. Expansion scientifique française. Paris. 1885. pp. 79-101.

15. Ciccotti M. G., Lombardo S. J., Nonweiler B., Pink M. Non-operative treatment of ruptures of the anterior eruciate ligament in the middle-aged patients: Results after long term follow-up. J. Bone Joint Surg. 1984. 76-A, 1315-1321.

16. Cross M. J., Wootton J. R. Bokor D. J., Sorrenti S. J. Acute repair of injury to the anterior cruciate ligament : A long-term follow-up. Am. J. Sports Med. 1998, 26. 128-131.

17. Dahlstedt L J., Dalen N.. Jonsson U. Extraarticular repair of the unstable knee : Disappointing 6 year results of the Slocum and Ellison operations. Acta Orthop. Scand. 1988, 59, 687-691. 
18. Dandy D. J., Gray A. J. Anterior cruciate ligament reconstruction with the Leeds-Keio prosthesis plus extraarticular tenodesis. J. Bone Joint Surg., 1994, 76-8, 193197.

19. Dandy D. J. Historical overview of operations for anterior cruciate ligament rupture. $\mathrm{K}$ nee Surg. Sports Traumatol. Arthroseopy. 1996, 3, 256-261.

20. Daniel D, Stone M. L., Dobson B. et al. Fate of the ACL-iajured patient. A prospective outcome study. Am. J. Sports Med., 1994, 22, 632-643.

21. Dehaven K. Meniscus repair in the athlete. Clin. Orthop.. 1995, 198, 31-35.

22. Dempsey S. M., Tregonning R. S. Vine-year follow-up results of two methods of Macintosh anterior eruciate ligament reconstructions. Clin. Ortbop., 1993, 294, 216222.

23. Denti M., Bigoni M., Dodaro G., Monteleone M.. Arosio A. Long term results of the Leeds-Keio anterior cruciate ligament reconstruction. Knee Surg. Sports Traumatol. Arthroscopy, 1995, 3, 75-77.

24. De Senedt M. Les prothèses du ligameat croisé antérieur : analyse d'ube echec. Acta Orthop. Belg. 1998, 64, 422. 433.

25. Dye S. The knee as a biologic transmission with an envelope of function. A theory. Clin. Ortbop., 1996, 323. $10-186$.

26. Engebretsen L. Benum P., Sundalsvold S. Primary surure of the anterior cruciate ligameat : A 6-year follow-up of 74 cases. Acta Orthop. Scand., 1989, 60, 561-564.

27. Eriksson E. How good are the results of ACL reconstruction? Knee Surg. Sports Traumatol. Arthroseopy. $1997,5,137$.

28. Feagin J. A. Curt W. W. Isolated tear of the antenor cruciate ligament : S-year follow-up study. Am. J. Sports Med., 1976, 4, 95-100.

29. Feagin J. A. The syndrome of the tom anterior cruciate ligament. Orthop. Clin. North Am. 1979, 10, 81-96.

30. Frank C. B., Jackson D. W. The science of reconstruction of the anterior cruciate lisament. J. Bone Joint Surg. 19y7, 79-त, 1556-7376.

31. Fritschy D., Daniel D., Rossman D., Rangger C. Bone imaging after acute knee hemarthrosis. Knee Surg. Sports Traumatol. Arthroscopy, 1993, 1. 20-27.

32. Gillquist J. Repair and reconstruction of the ACL : Is it good enough? Arthroscopy, 1993, 9, 68-71.

33. Greis P. E., Steadman J. R. Revision of failed prosthetic anterior cruciate ligament reconstruetion. Clin. Orthop.. $1996,232,78-90$.

34. Groatvedt T., Engebretsen L. Benum P., Anda S. Extraarticular transposition of the patellar tendon for anterolateral instability of the knee. Acta Orthop. Seand. $1995,66,321-324$.

35. Grentvedt T., Engebretsen L. Rossvoll L. Smevic O.. Vilsen G. Companson between Magoetic Resonance Imaging finding and knee stability: Measurement after anterior cruciate ligament repair whth and whout aug. mentation : A five-to-seven-year follow-up of 52 patients. Am. J. Sports Med., 1995, 23, 729-735.

36. Grentvedt T., Engebretsen L., Benum P. et al. A prospective randomized study of three operations for acute rupture of the anterior cruciate ligament: a five-year follow-up of one hundred and thirty-one patients. J. Bone Joint. Surg., 1996, 78-A, 159-168.

37. Johnson R. J., Eriksson E., Haggmark T., Pope M. H. Five-to-10-year follow-up evaluation after reconstruction of the anterior cruciate ligament. Clin. Orthop. 1984, 183. $122-140$.

38. Johnson R. J., Beynnon B. D., Nichols C. S., Renström P. A. The treatment of the injuries of the $\mathrm{ACL}$. J. Bone Joint Surg., 1992, 74-A, 140-15I.

39. Johnson R, J. Revision ACL surgery, In : Fu F, Harner C. D., Vince K. G., eds. Knee surgery. Williams and Wilkins, Baltimore, 1994, pp. $877-895$.

to. Holmes P. F., James S. L., Larson R. L, Singer K. M. Jones D. C. Retrospective direct comparison of three intraarticular anterior cruciate ligament reconstructions. Am. J. Sports Med. 1991, 19, 596-600.

41. Kaplan N., Wickiewicz T., Warrea R.F. Primary surgea treatment of anterior cruciate ligament ruphures : A longterm follow-up study. Am. J. Sports Med. 1990. 18, 354 358.

42. KAolsky R. H., Gibbons D. F., Kwasny O., Schabus R.. Plenk H. Braided polypropylene augmentation device in reconstructive surgery of the ACL : Long term ctinical performance of 594 patients and short term arthroscopic results, failure analysis by scanning electron mictoscopy and synovial histomorphology. J. Orthop. Res. 1997. 15. $1-10$.

43. Klein W., Jensen K. U. Synovitis and arrificial ligaments. Arthroscopy, 1992, 8. 116-124.

4. Kornbiatt 1. Warren R. F., Wickiewiez T. L. Long term follow-up of anterior cruciate ligament reconstruction using the quadnceps tendon substitution for chronic anterior cruciate ligament insufficiency. Am. J. Sports Med., 1988, 16, 444-448.

45. Levitt R. L. Malinin R, Posada A., Michlow A. Reconstruction of anterior eruciate ligament with bonepatellar tendon-booe and Achilles tendon allografts. Clin. Orthop., 1994, 303, 67-78.

46. Lindstrand A. The ACL problem. Acta Orthop. Scand.. 1995, 66, 105-106.

47. Lundberg M., Messner K. Ten-year prognosis of isolated and combined medial collateral ligament ruptures: A matched comparison in 40 patients using clinical and radiographic evaluations. Am. J. Sports Med. 1997, 25. 2-6.

48. Maletins W., Gillquist J. Long term results of anterior cruciate ligament reconstruction with a dacron prosthesis : The frequency of osteoarthritis after seven to eleven years. Am. J. Sports Med., 1997, 25, $288-293$.

49. Makisalo S. E. Visuri T. Viljanen A., Jokio P. Reconstruction of the anterior cruciate ligament with carbon 
fibres: Unsatisfactory results after 8 years. Knee Surg. Sports Traumatol. Arthroscopy, 1996, 4, 132-136.

50. Marcace M., Zaffagnini S., lacono F. Neri M. P. Petitto A. Early versus late reconstruction for anterior cruciate ligament rupture: Results after five years of follow-up. Am J. Sports Med., 1995, 23, 690-693.

51. Marcace M., Zaffagnini S., Visani A. et al. Arthroscopic reconstruction of the anterior cruciate ligament with Leeds-Keio ligament in non-protessional athietes : Results after a minimum 5 years follow-up. Knee Surg. Sports Traumatol. Arthroscopy, 1996, 4, 9-13.

52. Meystre J. L. Vallotton J., Benvenuti J. F, Double semitendinous anterior cruciate ligament reconstruction : 10-year resuits. Knee Surg. Sports Traumatol. Arthroscopy, 1998, 6, 76-81.

53. Mitsou A., Vallianatos P., Piskopakis N., Maheras S. Anterior cruciate ligament reconstruction by over-the-top repair combined with popliteus tendon plasty. J. Bone Joint Surg. 1990, 72-B, 398-404.

54. Mitsou A.r. Vallianatos P. Reconstruction of the anterior cruciate ligament using a patellar tendon autograft. A long term follow-up. Int. Orthop, 1996, 20, 285-289.

55. Moyen D., Lerat J. L. A. Artificial tigaments for antenor cruciate replacement : A new generation of problems. J Bone Joint Surg. 1994, 76-B, 173-175.

56. Noyes F. R., Barber S. D. The effect of an extra-articuiar procedure on allograft reconstructions for chronic ruptures of the anterior cruciate ligament. $J$. Bone foini Surg., 1991, 73-A, 882-892.

57. Noyes F, R. Barber S. D. Reconstruction of the antenor cruciate ligament with human allograft: companson of carly and later results. J. Bone Joint Surg. 1996. 78-4. 524-537.

58. Noyes F. R., Barber-Westin S. Anterior cruciate ligament reconstruction with autogenous patellar tendon graft in patients with articular cartilage damage. Am. J. Sports Med., 1997, 25, 626-634.

59. O'Brien S. J.. Warren R. F., Wickiewicz T. L et al. The iliotibial band lateral sling procedure and its effect on the results of anterior cruciate ligament reconstruction. Am. J. Sports Med., 1991, 19, 21-25.

60. Otson E. J., Kang J. D. Fu F. H. et al. The biomechanical and histological effect of artificial ligament wear particles: in vitro and in vivo studies. Am. J. Sports $\mathrm{Mert}_{2}, 1988$. $16,558-570$.

61. Otto D., Pinczewski L. A., Clingeletter, A. Odell R. Fiveyear results of single-incision arthroscopic anterior cruciate ligament reconstruction with patellar tendon autograft. Am. J. Sports Med., 1998, 26, 181-188.

62. Pattee G. A., Fox J. M., Del Pinzo W., Friedman M. J. Four to ten year follow-up of unreconstructed anterior cruciate ligament tearn. Am. J. Sports Med. 1989. 17. 430-435.

63. Pritebard J. C., Drez D., Moss M.. Heck S. Long term follow-up of anterior cruciate ligament reconstructions using freeze-dried fascia lata allograits. Am. J. Sports Med. 1995. 23. 593-596.
64, Rackemann S., Robinson A.. Dandy D. J. Reconstruetion of the anterior cruciate ligament with an intraarticular patellar tendon graft and an extra-articular tenodesis: Results after six years. J. Bone Joint Surg. 1991, 73-B, 368-373.

65. Reid J. S., Hanks G. A., Kalenak A., Kottmeier S., Aronoff $\mathrm{V}$. The Ellison iliotibial-band transier for a tom anterior cruciate ligament of the knee : Long term followup. J. Bone Joint Surg., 1992, 74-A, 1392-1402.

66. Sandberg R. Balkfors B. The durability of anterior cruciate ligament reconstruction with the patellar tendon. Am. J. Sports Med., 16, 341-343. 1988.

67. Saragaglia D. Leroy J. M., Tournè Y., Pieard F., Abu A Zahab M. Résultats a moyen terme de 173 plasties du ligament croisé anténeur selon la technique de $\mathrm{Ma}_{2}$. cintosh renforcke par Kennedy-LAD, Rev. Chir, Orthop. 1994, 30, 230-238.

68. Sherman M. F., Lieber L., Bonamo J. R.. Podesta L., Reiter L. The long term follow-up of primary antenor cruciate ligament repair: Defining a rationale for augmentation. Am. J. Sports Med., 19, 243-255.

69. Shirakura K., Terauchi M.. Kizuki S., Moro S. Kimura $\mathrm{M}$. The natural history of untreated anterior eruciate tears in recreational athietes. Clin. Onhop.. 1995, 317 , 227-236.

0 . Sommerlath $K$. The importance of the meniscus in unstable knees. A comparatuve sudy. Am. J. Sports Med., 1989, 17, 773-777.

71. Sommeriath K. Lyshoim J.. Gillquist J. The long term course aiter treatment of acute antenor cructate ligament ruptures : A 9-16 year follow-up. Am. 1. Sports Med. $1991,19,156-161$.

72. Sommerlath $K_{\text {., Odensten }}$.. Lyshoim J. The tate course of acute partial antenor cruciate ligament tears: A 9 to 15-year-follow-up evaluation. Clin, Orthop. 1992. $281,152-158$.

73. Specchiuli F, Laforgia R. Mocei A. et di. Anterior cruciate ligament reconstruction: $\mathrm{A}$ comparison of 2 techniques. Clin. Orthop., 1995, 311. 142-147,

74. Taylor G. R., Fernandez G. N, Robertson J. A. Long term results of anterior cruciate teconstruction using a fascia lata graft. The Knce, 1996, 3, 145-149.

75. Trager D., Pohle K. Tsethimer W. Anterior cruciate ligament suture in comparison with plasty: a 5-yearfollow-up study, duch. Orthop. Trauma Surg. 1995, 114, 278-280.

76. Vergis A., Hindriks M., Gillquist J. Comparison of dyoamic knee laxity during active and passive motion versus static laxity. Acta Orthop. Seand., 1996. 67 (suppl 272), 99.

77. Wilson W. J., Lewis F. Scranton P. E. Combined reconstruction of the anterior cruciate ligament in competitive athletes. J. Bone Joint Surg, 1990, 72-A, 742-748.

78. Windsor R. E., Insaill J. N. Bone block itiotibial band reconstruction for anterior eruciate insufficiency : Followup note and minimum five-year follow-up period. Clin. Orthop., 1990, 250, 197-206 
79. Zavras T. D., MacKenney R. P., Amis A. A. The natural history of anterior cruciate ligament reconstruction using patellar tendon autograft. The Knee, 1995, 2, 211-217.

80. Zimmerman M. E.. Contiliano J. H., Parsons J. R.. Prewett A., Billotti J. The biomechanics and histopathology of chemically processed patellar tendon allografts for anterior cruciate ligament replacement. Am. J. Sports Med., 1994, 22, 378-386.

\section{SAMENVATTING}

P. P. CASTELEYN. De behandeling van letsels van de voorsie kruisband: heelkundig modeverschijnsel, persoonlijke voorkeur of wetenschappelijke gegrondheid? Een studie van middellange- en langetermijn resultaten.

De middellange en lange termijnresultaten van conservatieve en heelkundige behandelingen van voorste knuisbandletseis, werden door middel van literatuurstudie nagegaan. Enkel artikels met een minimale followup van 4 jaar werden hiervoor in aanmerking genomen. Wat de conservatieve behandelingen betreft, kon de literatuurstudie enkel 7 artikels terugvnden. met een totaal van 636 gevallen.

De artikeis betreffende de heelkundige behandelingen werden in 4 categorietn ingedeeld ; primair heelkundig herstel, vertegenwoordigd door 13 artikels (1205 gevallen, extra-articulaire tenodese, vertegenwoordigd door 4 artikets (232 gevallen), voorste knuisbandreconstructies, vertegenwoordigd door 26 artikels (2693) en prosthetische synthetische vervanging, vertegenwoordigd door 5 artikets ( 370 gevallen).

Wat ook het type behandeling is, geven de functionele scores ongeveer $70 \%$ goede en uitstekende resuitaten weer.

De klinische laxiteit blijft echter beduidend in bijna alle conservatief behandelde gevallen, in de helft van de gevallen met primair herstel, extra-articulaire tenodese en prosthetische vervanging en in bijna 1/3 van de gevallen met reconstructic van de voorste kruisband. De incidentie van secundaire heelkunde ter hoogte van de voorste kruisband was het laagst in de conservatief behandelde groep ( $4.6 \%)$, daar waar jecundaire heelkunde ter hoogte van de menisci het laagst was in de groep met reconstructie van de voorste kruisband (3.5\%). Nochthans evolueerde deze laatste groep, in vergelijking met de conservatief behandelde groep naar een hogere morbiditeit in verband met osteoarthrose. Sporteelname was wel belangrijker in de groep met reconstructie van de voorste kruisband.
Deze analyse biedt dus een wellicht meer realistische kijk op de resultaten van de behandeling van de voorste kruisbandletsels, en illustreert het verband tussen behandeling, activiteitsniveau en osteoarthrose.

\section{RẼSUME์}

P. P. CASTELEYI. Le traitement des lésions du ligament croisé antérieur : mode chirurgicale, préférence personnelle, ou évidence scientifique ? Étude des résultats à moyen et long terme.

Les résultats a moyen et long terme des traitements conservateurs et chirurgicaux des lésions du ligament croisé antérieur ont été évalués sur base d'une analyse de la littérature. Seules, les séries comportant un followup minimum de 4 ans ont été prises en considération. En ce qui concerne les traitements conservateurs. l'étude de la littérature ne permet de retrouver que sept articies comprenant au total 636 cas.

Les articles concernant les traitements chinurgicaux ont été répartis en quatre catégories: les réparations primaires, avec 13 articles (1205 cas) les ténodéses extraarticulaires, avec 4 articles (232 cas), les reconstructions du pivot central avec 26 articles (2693 cas) et les remplacements prothétiques du ligament croisé antérieur, avee 5 articles ( 370 cas).

Les scores fonctionnels atteignent à peu près $70 \%$ de bons et excellents resultats, quel que soit le traitement. $\mathrm{L}$ a laxite clinique persiste dans quasi tous les cas traités de façon conservatrice, dans prés de la moitié des cas des réparations primaires, des ténodèses extraarticulaires, et des remplacements prothétiques, et dans quasi un tiers des reconstructions du ligament croisé antérieur. L'incidence d'interventions de reconstruction secondaire du pivot central, est la plus faible dans le groupe des traitements conservateurs $(4.6 \%)$, alors que l'incidence de la chirurgie méniscale secondaire est la plus basse dans le groupe des reconstructions du pivot central (3.5\%). Cependant, les traitements chirurgicaux évoluent plus souvent que les traitements conservateurs vers une morbidité like à arthrose. $\mathrm{L} a$ pratique sportive est cependant plus importante dans le groupe des reconstructions chirurgicales.

Cette analyse de la littérature permet une appréciation plus réaliste des résultats des traitements des lesions du ligament croisé antérieur, et met en exergue les relations entre traitement, niveau d'activité et arthrose. 


\section{GENERAL CONCLUSION AND PROPOSAL OF KNEE MANAGEMENT ALGORITME}

\section{A. Summary and General Conclusions :}

Recreational and sports activities, work and traffic conditions have created an epidemic of knee injuries.

The current trend toward cost-restricted and outcome-oriented medical care imposes a cheap, accessible, and reproducible way to screen these knee injuries and differentiate between more benign and rather serious lesions.

The presence of an hemarthrosis, to be verified by arthrocentesis can be this screening determinant . (Gillquist '77, Dehaven ' 80 , Casteleyn '88, Frank ' 88 , Bomberg' 90 ).

* If no hemarthrosis is present, there can still be a meniscal injury. The clinical diagnostic accuracy for the latter is fairly good (O'Shea '96), and arthrography does not yield a higher accuracy rate. M.R.I. has an higher accuracy rate, but its use has to be restricted, for cost and accessibility related reasons to cases with a doubtfull clinical diagnosis (Carmichael '97, Dandy '97, Dixon '96).

Arthroscopy seems to have a similar diagnostic accuracy as M.R.I. . Because of its morbidity, which even if rather low is not nihil, and again because of health care costs reasons, arthroscopy has to be used as a treatment procedure, and not as a purely diagnostic procedure (Boden '90, Rangger '96). 
Concerning chondral lesions, the clinical diagnosis fares much poorer than for meniscal lesions, and here the diagnostic accuracy of M.R.I., even if lower than for meniscal injuries, is interesting (Gylis-Morin '87, Handelberg '89, Shahabpour '97).

The cost-effectiveness of M.R.I. is highest in the differential diagnosis between meniscal and chondral lesions in doubtfull cases, where arthroscopic treatment will not be mandatory for all patients .

If an hemarthrosis is present, the main suspected diagnoses are a patellar dislocation, or an ACL injury, associated or not with lesions to other articular structures. The diagnosis of the former is clinically often missed, as the presence of a massive hemarthrosis is the only constant clinical sign. Arthroscopy on the other hand will precisely diagnose the acute dislocation, and evaluate the associated chondral lesions (Dainer '88. Casteleyn '89, Schaffer '95, Sallay '95). The relevance of this arthroscopic diagnosis on further treatment outcome is however not established.

The clinical diagnosis of $\mathrm{ACL}$ lesions is more worrisome.

Clinical laxity tests, and the use of instrumented laxity testing devices have increased the clinical diagnostic accuracy (Torg '76, Galway '72, Daniel '84, Daniel '85).

A positive Lachmann or instrumented Lachmann sign is pathognomonic of a forn ACL. A negative Lachmann is however still possible, in the presence of a torn $\mathrm{ACL}$, due to a displaced meniscal fragment, the joint effusion, and the pain and muscle guarding in the acute setting (Casteleyn '88. Frank '95). The Lachmann test is also dependent on the experience of the examinator, on the extend of the ACL tear, and on the mechanical qualities of the secondary restrains (Noyes '91, Bjordal '97). 
In the acute setting, the laxity tests will demonstrate a considerable number of false negative results (Noyes ' 80,0 'Shea '96, Dehaven ' 80 ).

Reexaminations after some time, to allow subsidence of the joint and soft tissue effusion, and to try to provide a more painfree examination with less muscle guarding, could be a valuable alternative to enhance the clinical diagnostic accuracy.

This approach has however unfil now not been validated and the precise clinical diagnosis of partial ACL lesions as well of the associated lesions will even then remain low.

Radiology - notwithstanding Segonds'sign - and ultrasound are of limited diagnostic aid (Graf '89).

Stress radiology only slightly enhances the diagnostic accuracy compared with the use of arthrometers (Dejour ' 89 , Lerat ' 88 , Staubli ' 91 ) and M.R.I., in the acute setting is not vastly superior to the clinical diagnostic accuracy, concerning the ACL lesion (Casteleyn '93, Liu '95, Adalberth '94). It is however more valuable concerning the associated lesions.

The examination under anesthesia provides a clear diagnosis in the majority of cases, but still $10 \%$ of all $\mathrm{ACL}$ injuries can be missed, and the complementary diagnostic information on associated lesions remains fragmentary (Noyes '80, Casteleyn '81, Pattee '89, Dahlstedt '89).

Only arthroscopy can guaranty a precise and complete diagnosis of all $\mathrm{ACL}$ injuries and of all associated lesions.

The first priority in the treatment of all $\mathrm{ACL}$ lesions is the treatment of the associated lesions, especially concerning the menisci. Limiled partial meniscectomies, and surgical meniscal repairs will allow a maximal maintenance of the "meniscal stock" and reduce the progression to osteoarthritis (Dehaven '85, Fowler '87, Barber '97). 
The choice between the conservative and the surgical treatment of the ACL lesion itself depends chiefly on the extend of the lesion (total versus partial), the resultant laxity, and the future activity level.

Age - as opposed to the usual age-related decline in strenuous physical activity levels - does not seem to influence the outcome and therefore the treatment indication (Barber '97).

The exact extend of a partial ACL lesion can be difficult to evaluate, but, in the absence of a gross pivot shift, conservative treatment is certainly a valuable treatment option, in the light of the fairly good outcome results (Noyes ' 89 ).

Further evaluation to assess eventual progression of $\mathrm{ACL}$ deficiency is however mandatory.

On the other hand, grossly unstable knees, with multidirectional laxity and marked pivot shift, are at major risk of giving-way, reinjury, repetitive meniscal injury, and osteoarhrosis. These knees probably always need a surgical ACL reconstruction (Shelbourne '97, Bray '89).

However, the analysis of long-term treatment results demonstrates that even surgical $\mathrm{ACL}$ reconstruction cannot totally restore knee homeostasis, and cannot avoid secondary osteoarthritis in case of joint overloading (Dye '96, Küllmer '94).

A crucial element in the treatment of $\mathrm{ACL}$ lesions is therefore the honest information of the patient on the relationship beween ACLpathology induced osteoarthritis and activity levels, and concerning the to be expected results and morbidity of conservative and surgical treatment (Sommerlath '92, Gillquist' '93, Ishibashi' '97).

For professional athletes, socio-economical factors will also interfere with the decision -making. 
For all other patients with total ACL disruption, the treatment indication depends on the informed patient's decision to comply or not with a reduced - activity level compatible with knee homeostasis.

If a moderate activity level, without or with reduced cutting, pivoting and jumping activities can be accepted by the patient, then a conservative treatment can be considered (Sommerlath '92, Shelton '97, Dye '96). This implies a rehabilitation program aimed at muscle strength and coordination training, mainly with closed chain exercises.

Postural stabilisation and proprioceptive enhancement (Caraffa '96) are also useful.

Functional braces can be used for some recreational activities, but their efficiency remains controversial.

Further reevaluation, with clinical laxity testing is again mandatory to detect an increase of knee laxity through overstraining of the secondary restrains. Bone scanning can monitor the knee homeostasis (Dye '93).

If laxity progresses or if the bone scanning remains disturbed despite activity - compliance, the activity has to be further adapted, or a surgical reconstruction considered.

Primary surgical reconstruction can be an informed patients choice in order to maintain a desired level of activity.

One has however to be cautious that this reconstruction precisely does not open the way to joint overloading, disruption of knee homeostasis and osteoarthritis (Gillquist '93, Eriksson '97). Further monitoring of knee homeostasis with bone scanning after $\mathrm{ACL}$ reconstruction is therefore probably advisable. 
A treatment algoritme which is essentially based on the concept of knee homeostasis could raise questions if arthroscopy still has a key role to play in the decision making.

The arthroscopic evaluation of acute traumatic knee hemarthrosis remains however mandatory :

it is the only diagnostic procedure which, if associated with an examination under anesthesia, yields a complete and precise diagnosis of all lesions (Casteleyn "88). The "natural history" reports of - often undiagnosed - $\mathrm{ACL}$ lesions have demonstrated the deleterious effects of the absence of diagnosis, counseling and treatment, with progressive joint destruction and osteoarthritis (Bray '89, Noyes '83, Irvine '92).

Patient counseling and information, the key to the treatment algoritme is only possible with a complete and precise diagnosis of the $\mathrm{ACL}$ and associated lesions.

The latter, particularly of the menisci, are present in a majority of $\mathrm{ACL}$ ruptures. They can be treated during the same arthroscopic procedure, preserving a maximal "meniscal stock", especially in patients in whom no further surgical reconstruction of the ACL will be considered.

In patients in which a reconstruction will be performed - after some weeks to reduce the risk of arthrofirbrosis (Mohtadi '91, Shelbourne '96) - it will reduce the further surgical procedure to this reconstruction.

The arthroscopic evaluation of the acute knee hemarthrosis, and the subsequent lavage of the articulation of most blood, can maybe reduce or abolish another biologic cascade of events, leading to osteoarthritis, and induced by the hemarthrosis itself (Lohmander ' 93 . 94). 
B. Knee injury managment algoritme

\section{ACUTE KNEE INJURY}

\section{ARTHROCENTESIS :}

$\Rightarrow$ No hemarthrosis : Clinical Evaluation

$\rightarrow$ meniscal lesion $\rightarrow$ Arthroscopic repair / meniscectomy

$\rightarrow$ chondral lesions

$\rightarrow$ doubt ? $\rightarrow$ MRI

$\Rightarrow$ Hemarthrosis : Examination and Arthroscopy under anesthesia

$\rightarrow$ patellar dislocation

$\rightarrow \mathrm{ACL}$ lesion \pm associated meniscal lesion $\downarrow$

Primary arthroscopic repair/meniscectomy

$\downarrow$

Information \& counseling :

$\rightarrow$ partial ACL $\longrightarrow$ conserv. treatment (neg. pivot shift)

$\rightarrow$ total $\mathrm{ACL}$

(or partial ACL with pos. pivot shift)

$\rightarrow$ activity adaptation

$\rightarrow$ no activity adaptation 
ADALBERTH T, ROOS H, LAUREN M, AKESON P, SLOTH M, JOHNSSON K, LINDSTRAND A, LOHMANDER LS

Magnetic Resonance Imaging scintigraphy and crthroscopic evaluation of traumatic hemarthrosis of the knee.

Am. J. Sports Med. $25: 231-237,1997$

BARBER FA, ELROD BF, MCGUIRE DA, PAULOIS LE

Is an anterior cruciate ligament reconstruction outcome age dependent? Arthroscopy $12: 720-725,1996$

BJORDAL JM, ARNØY F, HANNESTAD B, STRANDT T

Epidemiology of anterior cruciate ligament injuries in soccer.

Am. J. Sports Med. $25: 341-345,1997$

BODEN SD, LABROPOULOS PA, VAILAS JC (1990)

MR scanning of the acutely injured knee : sensitive, but is it cost

effective?

Arthroscopy $6: 306-310,1990$

BOMBERG CB, MAC GINTY JB

Acute hemarthrosis of the knee : indications for diagnostic arthroscopy.

Arthroscopy $6: 221-225,1990$

BRAY R, DANDY D

Meniscal lesions and chronic anterior cruciate ligament deficiency. Meniscal tears occuring before and after reconstruction.

J. Bone Joint Surg. 71 B : 128 - 130, 1989 
CARAFFA A, CERULLI G, PROJETII M, AISA G, RIZZO A

Prevention of anterior cruciate ligament injuries in soccer. A prospective control study of proprioceptive training.

Knee Surg. Sports Traumatol. Arthroscopy 4 : 19 - 21, 1996

CARMICHAEL IW, MaCLEOD AM, TRAVLOS J

M.R.I. can prevent unnecessary arthroscopy.

J. Bone Joint Surg. 79-B : 624 - 625, 1997

CASTELEYN PP, HANDELBERG F, OPDECAM P

Traumatic hemarthrosis of the knee.

J. Bone Joint Surg. 70 B: 404 - 406, 1988

CASTELEYN PP, HANDELBERG F

Arthroscopy in the diagnosis of occult dislocation of the patella.

Acta Orthop. Belg. $55: 381-383,1989$

\section{CASTELEYN PP, HANDELBERG F}

Technicas de diagnostico por la imagen.

In : Principios de artroscopia y cirurgia arhtroscopica.

Zarins B, Cugat R. Ed.

Springer-Verlag, Barcelona p. 56 - 65, 1993

DAHLSTEDT LJ, DALEN N

Knee laxity in cruciate ligament injury. Value of examination under anesthesia.

Acta Orthop. Scand. $60: 181-184,1989$

DAINER RD, BARRACK RL, BUCKLEY SL, HERBERT ALEXANDER A Arthroscopic treatment of acute patellar dislocations.

Arthroscopy $4: 267-271,1988$ 


\section{DANDY J}

Arthroscopy and M.R.I. for the knee.

J. Bone Joint Surg. 79 B : 520,1997

DANIEL DM, STONE ML, SACHS R, MALCOM L

Instrumented measurement of anterior knee laxity in patients with acute anterior cruciate ligament disruption.

Am. J. Sports Med. 13: $401-407,1985$

\section{DEHAVEN KE}

Diagnosis of acute knee injuries with hemarthrosis.

Am. J. Sports Med. 8, 9 - 14, 1980

\section{DEHAVEN KE}

Meniscus repair in the athlete.

Clin. Orthop. 198:31-35, 1985

\section{DEJOUR H, WALCH G, NEYRET PH, CHAMBAT P}

Subluxation active en extension après rupture du ligament croisé antérieur : mesure radiologique et apport diagnostique.

J. Traumatol. Sport 6: $22-27,1989$

\section{DIXON AK}

Magnetic resonance imaging of meniscal tears of the knee.

J. Bone Joint Surg. 78 B : 174 - 175, 1996

\section{DYES}

The knee as a biologic transmission with an envelope of function. A theory.

Clin. Orthop. $323: 10-18,1996$ 


\section{DYES. CHEW MH}

The use of scintigraphy to detect increased osseous metabolic activity about the knee.

J. Bone Joint Surg. 75 A : 1388 - 1406, 1993

\section{ERIKSSONE}

How good are the results of $A C L$ reconstruction?

Knee Surg. Sports Traumatol. Arthroscopy 5: 137, 1997

FRANK A, BEAYFILS Ph. RUA R, BENOIT J

L'arthroscopie dans les hémarthroses posttraumatiques du genou.

Rev. Chir. Orthop. 74, Supll. II : 177 - 180, 1988

FRANK CB, GRAVEL JC

Hamstring spasm in anterior cruciate ligament injuries.

Arthroscopy $11: 44-448,1995$

FOWLER P, REGAN W

The patient with symptomatic chronic anterior cruciate ligament insufficiency. Results of minimal arthroscopic surgery and rehabilitation. Am. J. Sports Med. 15:321 - 326, 1987

GALWAY rd, BEAUPRE A, MC INTOSH DC

Pivot shift : a clinical sign of symptomatic ACL insufficiency

J. Bone Joint Surg. 54 B: $763-776,1972$

\section{GRAF R}

Sonographie am bewegungsapparat.

Orthopädie 18:2 - 11, 1989 


\section{GILLQUIST J, HAGBERG G, ORETOP N}

Arthroscopy in acute injuries of the knee joint.

Acta Orthop. Scand. $48: 190-196,1977$

\section{GILLQUIST J}

Repair and reconstruction of the $\mathrm{ACL}$ : is it good enough ? $\mathrm{A}$ commentary.

Arthroscopy $9: 68-71,1993$

GYLYS-MORIN V, HAJEKP, SARTORIS D, RESNICK D

Articular cartilage defects. Detectability in cadaver knees with MR.

Am. J. Radiol. 148: 1053 - 1157, 1987

HANDELBERG F, SHAHABPOUR M, CASTELLEY PP

Chondral lesions of the patella evaluated with computed tomography, magnetic resonance imaging and arthroscopy.

Arthroscopy 6:24-29, 1990

IRVINE G, GLASHOW M

The natural history of the meniscus in anterior cruciate insufficiency. Arthroscopic analysis.

J. Bone Joint Surg. 74 b: 403 - 405, 1992

ISHIBASHI Y, RUDY T, LIVESAY G, STONE J, FU F, WOOS.

The effect of anterior cruciate ligament graft fixation stite at the tibia on knee stability : evaluation using a robotic testing system.

Arthroscopy 13:177 - 182, 1997 
KÖLLMER K, LETSCH R, TUROWSKI B

Which factors influence the progression of degenerative osteoarthritis after ACL surgery ?

Knee Surg. Sports Traumatol. Arthroscopy 2 : 80 - 84, 1994

LERAT JL, MOYEN B, DUPRE-LATOUR L, MAINETTI E, LALAIN JJ, BRUNET E Mesure des laxités antérieures du genou par radiographies dynamiques ef par l'arthromètre KT 1000.

Rev.Chir. Orthop. 74, Suppl II : $194-197,1988$

LIU SH, OSTI L, HENRY M, BOCCHI L

The diagnosis of acute complete tears of the anterior curiciate ligament . Comparison of M.R.I. , arthrometry and clinical examination.

J. Bone Joint Surg. 77 B - 586 - 588, 1995

\section{LOHMANDER L, HOERRNER L}

Metalloproteinases, tissue inhibitor, and proteoglycan fragments in knee synovial fluid in human osteoarthritis.

Arthritis Rheum. 36:181-189, 1993

LOHMANDER L, ROOS H, DAHLBERG L, HOERRNER L, LARK M

Temporal patterns of Stromelysin - 1, tissue inhibitor, and proteoglycan fragments in human knee joint fluid after injury to the cruciate ligament of meniscus.

J. Orthop. Res. $12: 21-28,1994$

MOHTADING, WEBSTER-BOGAERT S, FOWLER PJ

Limitation of motion following anterior cruciate ligament reconstruction : a case-control study.

Am. J. Sports Med. $19: 620-625,1991$ 
NOYES FR, BASSET RW, GROOD ES, BUTLER DL

Arthroscopy in acute traumatic hemarthrosis of the knee. Incidence of anterior cruciate tears and other injuries.

J. Bone Joint Surg. 65 A : 154 - 162, 1983

NOYES FR, MOOAR LA, MOORMAN CT, MC GINNIS JH

Partial tears of the anterior cruciate ligament. Progression to complete ligament deficiency.

J. Bone Joint Surg. 71 B : 825 - 833, 1989

O'SHEA KJ, MURPHY KP, HEEKIN RD, HERZWURM PJ

The diagnostic accuracy of history, physical examination, and radiographs in the evaluation of traumatic knee disorders.

Am. J. Sports Med. 24 : 164 - 167, 1996

PATTEE GA, FOX JM, DEL PIZZO W, FRIEDMAN MJ

4 to 10 year follow-up of unreconstructed $\mathrm{ACL}$ tears .

Am. J. Sports Med. 17: 430 - 435, 1989

RANGGER C, KLESTIL T, KATHREIN A, INDERSTER A, HAMID L

Influence of magnetic resonance imaging on indications for arthroscopy of the knee.

Clin. Orthop. $330: 133-142,1996$

\section{SALLAY PI, GARETT WE}

Acute dislocation of the patella: A correlative pathoanatomical study. Proc. am. Acad. Orthop. Surg. 337, 1995

SCHAFFER N, LEHMANN M, MULLER W

Arthroscopic repair of the medial refinaculum and capsule in acute patellar dislocations.

Proc. Am. Acad. Orthop. Surg. 337, 1995 
SHAHABPOUR M, TEBACHE C. CASTELEYN PP, HANDELBERG F, LEROUX GB. MACHIELS F, DE MAESENEER M, OSTEAUX M

IRM du cartilage : comparaison IRM arthroscopie, à propos de 320 cas.

In : Le genou traumatique et dégénératif.

Bard H. Drape JL, Goutallier D, Laredo JD Ed.

Sauramps Medical Montpellier, p. 161 - 176, 1997

SHELBOURNE K, PATEL D, MARTINI D

Classification and management of arthrofibrosis of the kn,ee after anterior cruciate ligament reconstruction.

Am. J. Sports Med. : $24: 857$ - 868,1996

SHELBLOURNE K, STUBE K

Anterior cruciate ligament - deficient knee with degenerative arthrosis : treatment with an isolated autogenous patellar tendon $\mathrm{ACL}$ reconstruction.

Knee Surg. Sports Traumatol. Arthroscopy 5 : 150 - 156, 1997

SHELTON W, BARETI G, DUKES A

Early season anterior cruciate ligament tears.

A treatment dilemma.

Am. J. Sports Med. 25: 656 - 658, 1997

SOMMERLATH K, GILLQUIST J

the long-term course of various meniscal treatments in anterior cruciate ligament deficient knees.

Clin. Orthop. $283: 207-214,1992$

TORG JS, CONRAD W, KALEN V

Clinical diagnosis of $\mathrm{ACL}$ instability in the athlete.

Am. J. Sports Med. $4: 84-93,1976$ 


\section{SAMENVATIING}

De toename van sport- en vrijetijdsactiviteiten, en de actuele werk- en verkeersomstandigheden hebben geleid tot een epidemische toename van knietraumata. In het raam van de huidige tendens tot klinische beoordeling van het medisch handelen, en van de beperking van de medische uitgaven, is het aangewezen dat een eenvoudige en goedkope screeningstechniek zou gevonden worden, om op reproduceerdbare wijze een onderscheid te maken tussen eenvoudige benigne, en meer belangrijke letsels .

Dit onderscheid kan berusten op de aanwezigheid of niet van een hemarthrose. Deze laatste wordt vastgesteld door een gewrichtspunctie.

Indien er geen hemarthrose aanwezig is, kan het trauma een meniscaal of chondraal letsel veroorzaakt hebben.

Wat meniscale letsels betreft is de klinische diagnostische accuraatheid vrii goed, en wordt deze laatste niet verbeterd door arthrografie. Het onderzoek met magnetische resonantie geeft wel een verhoogde graad van accuraatheid. Het gebruik van magnetische resonantie moet echter beperkt worden tot gevallen met klinische diagnostische twijfel, en dit oa. om redenen van kostprijs.

De arthroscopie biedt een gelijkaardige diagnostische accuraatheid als magnetische resonantie. Arthrosopie moet echter eerder beschouwd worden als een behandelingsprocedure, niet als een zuivere diagnostische procedure, omwille van de hiermede gepaard gaande morbiditeit. Zelfs indien deze laag is, is ze niet onbestaande. Anderzijds is de kost van de diagnostische arthroscopie hoger dan deze van de magnetische resonantie. 
Wat de kraakbeenletsels betreft, is de klinische diagnose ontoereikend. Ook hier is de diagnostische accuraatheid van magnetische resonantie hoger. Op het vlak van de kostenbaatanalyse, is het gebruik van magnefische resonantie aangewezen in de differentiaal diagnose fussen meniscale en chondrale letsels, gezien hierbij een arthroscopische behandeling nieł noodzakelijk zal zijn voor alle patiënten.

Indien een hemarthrose door gewrichtspunctie wordt gevonden, kan men òf een dislocatie van de patella, òf een letsel van de voorste kruisband, al dan niet geassocieerd met letsels van de andere intraarticulaire structuren vermoeden.

Men stelt vast dat de klinische diagnose van patelladislocatie frequent gemist wordt. Het enige constant klinisch teken is hierbij de massieve hemarthrose. Arthroscopie laat een precieze diagnose toe van patelladislocatie, samen met een evaluatie van eventuele kraakbeenletsels.

Er zijn echter geen gegevens beschikbaar over de invloed van deze precieze arthroscopische diagnose op verdere behandeling en evolutie van deze pathologie.

Wat de klinsche diagnose betreft van letsels van de voorste kruisband, is deze zonder twiffel verbeterd door het gebruik van specifieke laxiteitstesten, en het meten van de laxiteit, met aangepaste arthrometers.

Een positief teken van Lachmann of een teken van Lachmann bij arthrometrisch onderzoek is pathognomisch voor een voorste kruisbandruptuur. Het is echter mogelijk dat bij het klinische onderzoek er een negatief Lachmann-teken is, alhoewel er effectief een kruisbandruptuur bestaat. 
Dit kan door een verplaatsing van een meniscaal fragment, door de vochtuitstorting in het gewricht, en door de pijn welke een spierspanning veroorzaakt, bij acute gevallen.

De accuraatheid van de Lachmann-test blijkt af te hangen van de ervaring van de onderzoeker, van de vitbreiding van de kruisbandscheur en van de mechanische eigenschappen van de secundaire ligamentaire gewrichtsstabilisatoren.

In acute gevallen zouden klinische laxiteitstesten een vrij behoorlijk aantal vals-negatieve resultaten weergeven. Een heronderzoek van de patiënt, na enige tijd is een mogelijk alternatief om de klinische accuraatheid te verhogen. Inderdaad door een vermindering van de vochtuitstorting in het gewricht en in de weke weefsels, kan een meer pijnvrij onderzoek mogelijk zijn, met minder spierspanning.

Deze aanpak werd tot nu toe echter niet op grondige wijze onderzocht. Anderzijds blijtt een precieze klinische diagnose van partiële letsels van de voorste kruisband moeilijk.

Het radiologisch onderzoek - tenzij in de aanwezigheid van het teken van Segond - en het echografisch onderzoek brengen weinig bij tot de diagnose. Het stress radiologisch onderzoek is vergelijkbaar met het gebruik van klinische arthrometers. In acute omstandigheden is de diagnostische accuraatheid van magnetische resonantie voor letsels van de voorste kruisband niet hoger dan de klinische accuraatheid. Magnetische resonantie geeft echter nuttige informatie betreffende geassocieerde letsels.

Het onderzoek van de knie onder narcose biedt een duidelijke diagnose in de meerderheid van de gevallen, maar ongeveer $10 \%$ van de voorste kruisbandletsels wordt zelfs in deze omstandigheden nog gemist. 
Ook biedt het onderzoek onder narcose geen bijkomende informatie betreffende de geassocieerde letsels.

Enkel de arthroscopie kan een precieze en volledige diagnose van alle voorste kruisbandletsels, en alle geassocieerde letsels waarborgen.

De eerste prioriteit bij de behandeling van voorste kruisbandtraumata is de behandeling van de geassocieerde letsels, in het bijzonder van de menisci. Beperkte partiële meniscectomieën, en het heelkundig herstel van de menisci laten een maximaal behoud toe van de "meniscale stock" en verminderen derhalve de mogelijke progressie naar arthrose.

De keuze fussen een conservatieve of heelkundige behandeling van het voorste kruisbandletsel zelf, berust voornamelijk op de uitbreiding van het letsel (gedeeltelijk of totaal), de gewrichtslaxiteit, en het verder niveau van fysieke activiteit. De ouderdom op zichzelf lijkt geen invloed te hebben op de verdere evolutie en de keuze van de behandeling. Wel moet hierbij rekening gehouden worden met de normale vermindering, in verband met de leeftijd, van het fysieke activifeitsniveau.

Alhoewel de precieze omvang van een gedeeltelijk letsel van de voorste kruisband moeilijk te evalueren is, is een conservatieve behandeling hiervoor aangewezen, op basis van de relatief goede functionele resultaten.

Bij de conservatieve behandeling van deze gedeeltelijke letsels, is een verdere klinische opvolging noodzakelijk, om een eventuele progressie van de laxiteit op te volgen.

Een vitzondering hierop zijn knieën met een belangrijke laxiteit, wat tot viting komt door een overduidelijk positief pivot shift-teken. 
Hogervernoemde knieën met een zeer belangrijke laxiteit, vormen een risicogroep waar doorzakking, repetitief knietrauma en meniscale letsels leiden tot osteoarthrosis. Deze knieën vergen waarschijnlijk altijd een voorste kruisbandreconstructie.

De meta-analyse van de resultaten van volledige voorste kruisbandletsels op middellange termijn toont aan dat de heelkundige reconstructie van de kruisband geen volledig herstel biedt van de kniehomeostase en secundaire osteoarthrose niet kan voorkomen, in geval van gewrichtssurmenage.

Een centraal element in de behandeling van kruisbandletsels is derhalve de eerlijke informatie van de patiënt betreffende de mogelijke evolutie naar osteoarthrose, in verband met het acitiviteitsniveau, en de te verwachten resultaten en morbiditeit, zowel bil conservatieve als heelkundige behandeling.

Voor professionele atleten kunnen socio-economische factoren ook een rol spelen bij deze keuze. Voor alle andere patiënten met een volledige voorste kruisbandscheur, moet de behandelingsindicatie berusten op het aanvaarden door de patiënt van een activiteitsniveau dat compatibel is met het behoud van een kniehomeostase.

Indien de patiënt een matig activiteitsniveau kan aanvaarden, zonder activiteiten die draaibewegingen, brutale richtingsveranderingen, en springen, inhouden, dan kan een conservatieve behandeling overwogen worden. Dit veronderstelt het toepassen van een rehabilitatie programma gericht op splerversterking en coördinatie, in hoofdorde met gesloten ketenoefeningen.

Posturale stabilisatie en verbetering van de proprioceptie zijn eveneens aangewezen. Het gebruik van functionele braces kan nuttig zijn bij 
bepaalde recreationele activiteiten maar er bestaat duidelijk geen eensgezindheid over het nut van deze braces.

Bij een conservatieve behandeling is periodische reëvaluatie van de klinische laxiteit aangewezen, hierdoor kan een eventuele toename van de laxifeit door overbelasting van de secundaire ligamentaire gewrichtsstabilisatoren nagegaan worden.

Botscintigrafie kan het behouden van de kniehomeostase nagaan.

Indien de klinische laxiteit toeneemt of indien de botscintigrafie positief blijft ondanks de aanpassing van het activiteitsniveau, dan hoeft een heelkundige reconstructie van de voorste kruisband overwogen te worden.

Een dergelijke primaire heelkundige reconstructie kan overwogen worden, indien de patiënt een bepaald hoog activiteitsniveau wenst te behouden.

Men moet echter behoedzaam zin dat een heelkundige reconstructie niet de weg baant naar een verdere overbelasting van het gewricht, met verstoren van de kniehomeostase en hieruitvolgende osteoarthrose.

Een verdere evaluatie van de kniehomeostase met botscintigrafie na een voorste kruisbandreconstructie is derhalve waarschijnlijk aan te raden.

In een behandelingsalgoritme dat in hoofdorde stoelt op het concept van de kniehomeostase kan men zich de vraag stellen of arthroscopie een belangrije rol speelt in de besluitvorming.

De arthroscopische evaluatie van de acute traumatische hemarthrose van de knie bliff echter noodzakelijk: 
het is de enige diagnostische techniek, welke, in associatie met een onderzoek van het gewricht onder narcose, een volledige en precieze diagnose kan bieden van alle knieletsels.

De zogenoemde "natuurlijke geschiedenis" studies van voorste kruisbandletsels hebben aangetoond wat de negatieve effecten zijn van een gebrek aan diagnose, raadgeving en behandeling, leidend tot progressieve gewrichts- beschadiging en osteoarthrose.

Een grondige patiënteninformatie en raadgeving, welke aan de basis ligt van het vooropgestelde behandelingsalgoritme is slechts mogelijk met een volledige en precieze diagnose van het voorste kruisbandletsel en de geassocieerde letsels.

Deze laatsten, en meer bepaald de meniscale letsels betreft, zijn aanwezig in een meerdheid van voorste kruisbandrupturen. Ze kunnen dan ook behandeld worden tijdens dezelfde arthroscopische zitting, wat leidt tot een maximaal behoud van de "meniscale stock", in het bijzonder bil patiënten waar een verder heelkundig herstel van de voorste kruisband niet zal overwogen worden.

Bii patiënten waar deze laatste reconstructie wel zal gebeuren, meestal na enkele weken later, om het risico van arthrofibrose te verminderen, wordt hierbil de reconstructieprocedure vereenvoudigd.

De spoeling en het verwijderen van het bloed uit het gewricht bij de arthroscopische evaluatie van de acute traumatische kniehemarthrose kan wellicht ook een biologische cascade, ontketend door de hemarthrose zelf, en eveneens leidend tot osteoarthrose, deels ongedaan maken. 


\section{AKUUT KNIELETSEL \\ $\rightarrow$ GEWRICHTSPUNKTIE}

$\Rightarrow$ Geen hemarthros: Klinische Evaluatie

$\rightarrow$ meniscaal letsel $\rightarrow$ Arthroscopisch herstel / meniscectomie

$\rightarrow$ chondraal letsel

$\leftarrow \rightarrow$ twijfel ? $\rightarrow$ MRI

$\Rightarrow$ Hemarthros: Onderzoek onder narcose en Arthroscopie

$\rightarrow$ patella dislocatie

$\rightarrow$ VKB letsel \pm meniscaal letsel

$\downarrow$

$\downarrow$

Primair arthroscopisch herstel/meniscectomie

Informatie \& raadgeving :

$\rightarrow$ gedeeltelijk VKB letsel $\longrightarrow$ conserv, behandeling (neg. pivot shift)

$\rightarrow$ totale VKB

(of gedeeltelijke VKB met pos, pivot shift)

$\rightarrow$ activiteitsaanpassing

$\rightarrow$ geen activiteitsaanpassing $\rightarrow$ VKB reconstructie

$\rightarrow$ grove laxiteit 
P.P. CASTELEYN werd geboren op 18 september 1946 in Antwerpen (België).

Na Grieks-Latijnse Humaniora studies aan het Onze-Lieve-Vrouw College te Antwerpen en het Koninklijk Atheneum te Berchem - Antwerpen vatte hij, in 1965 hogere studies aan in het zopas opgerichte Rijksuniversitair Centrum Antwerpen (R.U.C.A.).

In 1968 maakte hij deel uit van de eerste promotie die de titel van kandidaat in de Genees- en Natuurwetenschappen behaalde aan deze Universiteit.

Verdere studies in de Geneeskunde werden verricht aan de Vrije Universiteit Brussel (V.U.B.) waar de fitel van dokter in Genees- Heel- en Verloskunde behaald werd met Grote Onderscheiding in 1972.

In 1978 behaalde hij, eveneens met Grote Onderscheiding, de Licentie in Verzekeringsgeneeskunde en Evaluatie van Lichamelijke Schade, aan de Université Libre de Bruxelles (U.L.B.).

Na het beëindigen van de geneeskunde studies werd P.P. CASTELEYN gedurende 1 jaar tewerkgesteld door het Belgisch Nationaal Fonds voor Wetenschappelijk Onderzoek.

Hierbij werden zelfvermenigvuldigingspatronen in de maag-darmtractus bestudeerd. Simultaan werd een postgraduaatsopleiding in de Algemene Heelkunde aangevat, met klinische stages als resident in het Universitair St. Pieter-Ziekenhuis (prof. BREMER en prof. DANIS) te Brussel. 
Een erkenning als specialist in de Algemene Heelkunde werd behaald in 1978.

Gedurende deze opleiding in de Algemene Heelkunde groeide de interesse voor de Orthopedie en de Traumatologie, en na verdere stages als resident in de Centre Hospitalier Universitaire te Rijsel (prof. DE COULX) en in het Academisch Ziekenhuis van de Vrije Universiteit Brussel (prof. OPDECAM) werd in 1980 een erkenning als specialist in de Orthopedie en Traumatologie behaald.

Vanaf 1977 was P.P. CASTELEYN verbonden aan het Academisch Ziekenhuis van de Vrije Universiteit Brussel. Hij vervulde hierbij initieel zowel klinische als administratieve taken, bij de planning, oprichting, en opening van dit nieuw Academisch Ziekenhuis. Anecdotisch hierbili is het feit dat hil de eerste, door dit Ziekenhuis full-time tewerkgestelde aanwezige arts was.

P.P. CASTELEYN was hierbil ook opeenvolgend secretaris en Ondervoorzitter van de Medische Raad, en Ondervoorzitter van de Raad van Bestuur van het Academisch Ziekenhuis van de Vrije Universiteit Brussel.

De klinische en wetenschappelijke interesse en activiteit evolveerde progressief naar de studie enerzijds van de kniepathologie, anderzijds van de anatomie.

Dit leidde tot meer dan 140 mededelingen op wetenschappelijke congressen en symposia, 68 wetenschappelijke publicaties als eerste auteur, 85 wetenschappelijke publicaties als co-auteur, het auteurschap van 6 hoofdstukken en/of wetenschappelijke boeken, en het "editorschap" van 1 wetenschappelijk boek. 
P.P. CASTELEYN werd in 1984 benoemd tot Kliniekhoofd in de dienst Orthopedie en Traumatologie van het Academisch Ziekenhuis van de Vrije Universiteit Brussel en in 1991 tot Docent en Coördinator van de Leerstoel Menselijke Anatomie aan de Faculteit Geneeskunde en Farmacie van de Vrije Universiteit Brussel.

P.P. CASTELEYN is eveneens lid van talrijke wetenschappelijke verenigingen (Belgische Vereniging voor Orthopedie en Traumatologie, Société Internationale de Chirurgie Orthopédique et de Traumatologie, Société Internationale de Recherche en Orthopédie et Traumatologie, International Knee Society, International Arthroscopy Association. European Society for Knee Surgery Sports Traumatology and Arthroscopy, International Society of Arthroscopy, Knee Surgery and Orthopaedic Sports Medicine, American Academy of Orthopaedic Surgeons.

Ook werd hij in 1997 ere-lid van de Société Française de Chirurgie Orthopédique et de Traumatologie.

Hij was voorzitter van de Belgische Vereniging voor Orthopedie en Traumatologie in 1992 - 1993, is lid van het Bestuur van de European Federation of National Associations of Orthopaedics and Traumatology sinds 1994, en Chairman van het 4 de Congres van deze federatie, dat in 1999 in Brussel plaatsvond. 

